UNIVERSIDADE TECNOLÓGICA FEDERAL DO PARANÁ - UTFPR

MARCELO FORTUOSO

ESTUDO DO DESEMPENHO DE UM MOTOR DE COMBUSTÃO INTERNA TURBOALIMENTADO E COM RESTRIÇÃO DA ENTRADA DE AR

DISSERTAÇÃO DE MESTRADO

CURITIBA

2021 


\title{
ESTUDO DO DESEMPENHO DE UM MOTOR DE COMBUSTÃO INTERNA TURBOALIMENTADO E COM RESTRIÇÃO DA ENTRADA DE AR
}

\author{
Performance Study of an Internal Combustion Engine \\ Turbocharged and with Intake Air Restricted
}

Dissertação apresentada como requisito para obtenção do título de Mestre em Engenharia Mecânica, do Programa de Pós-Graduação em Engenharia Mecânica e de Materiais da Universidade Tecnológica Federal do Paraná (UTFPR) Campus Curitiba.

Orientador: Prof. Dr. José Antonio Andrés Velásquez Alegre

\section{CURITIBA}

2021 
Ministério da Educação

MARCELO FORTUOSO

\title{
ESTUDO DO DESEMPENHO DE UM MOTOR DE COMBUSTÃO INTERNA TURBOALIMENTADO E COM
} RESTRIÇÃO DA ENTRADA DE AR

\begin{abstract}
Trabalho de pesquisa de mestrado apresentado como requisito para obtenção do título de Mestre Em Engenharia da Universidade Tecnológica Federal do Paraná (UTFPR). Área de concentração: Engenharia Térmica.
\end{abstract}

Data de aprovação: 07 de Dezembro de 2021

Prof Jose Antonio Andres Velasquez Alegre, Doutorado - Universidade Tecnológica Federal do Paraná Prof Key Fonseca De Lima, Doutorado - Pontifícia Universidade Católica do Paraná (Pucpr) Prof Ricardo Alan Verdu Ramos, Doutorado - Universidade Estadual Paulista Júlio de Mesquita Filho (Unesp) 


\section{DEDICATÓRIA}

À minha esposa, Manuela Cristina Buch Soares, pelo apoio, carinho, amor, dedicação e por acreditar nesse trabalho se tornar possível.

Ao meu filho, Gustavo Buch Soares Fortuoso, por ser a alegria da minha vida, pelo amor que sinto por ele.

Aos meus pais, José Aparecido Fortuoso e Ana Lúcia Pires Fortuoso, por acreditarem em mim, pelo apoio, carinho, amor e dedicação.

Aos meus irmãos, Ronaldo Fortuoso e Nádia Fortuoso, pelo apoio e carinho.

Aos meus sogros, Jackson Grahl Soares e Aglae Rita Buch Soares, pelo apoio e dedicação.

Aos meus cunhados Luana do Nascimento Feitosa e Thiago Bernhard Calliari, pelo apoio e carinho.

Ao meu orientador, José Antonio Andrés Velásquez Alegre, pelos ensinamentos, apoio, dedicação e por ajudar tudo isso se tornar possível. 


\section{AGRADECIMENTOS}

A Deus, pelo amparo, proteção e pela vitória.

À Universidade Tecnológica Federal do Paraná, em especial ao Departamento de Engenharia Mecânica, pelo apoio e pela oportunidade de realizar o mestrado.

Ao professor Dr. José Antonio Andrés Velásquez Alegre, pela orientação, amizade e valiosos ensinamentos.

Agradeço a Yamaha Motor da Amazônia LTDA. por disponibilizar o motor para o estudo.

Agradeço a todos os membros da equipe de Fórmula SAE da UTFPR, pela dedicação e esforço.

Agradeço ao Lucas de Almeida Mathias pelo apoio na calibração do motor na injeção programável.

Agradeço ao Gabriel Batista Alves e Lucas Volkmann Cardoso pelo apoio nesse trabalho.

Agradeço a minha esposa Manuela Cristina Buch Soares, pela paciência, apoio, por acreditar que fosse possível.

Agradeço aos meus pais, José Aparecido Fortuoso e Ana Lúcia Pires Fortuoso, pelo apoio, pela educação que me foi dada e pelos seus esforços, que me forneceram a oportunidade de estar aqui.

Agradeço aos meus irmãos Ronaldo Fortuoso e Nádia Fortuoso, pelo apoio e fraternidade que apenas um irmão pode dar.

Agradeço aos meus sogros Jackson Grahl Soares e Aglae Rita Buch Soares, pelo apoio e dedicação dado nesse período. 
Seja você quem for, seja qual for a posição social que você tenha na vida, a mais alta ou a mais baixa, tenha sempre como meta muita força, muita determinação e sempre faça tudo com muito amor e com muita fé em Deus, que um dia você chega lá. De alguma maneira você chega lá. 


\section{RESUMO}

O presente trabalho descreve a melhoria de desempenho e de rendimento conseguida em um motor que será utilizado na competição Fórmula SAE. Trata-se de um motor fabricado pela empresa Yamaha, com 320 cc de cilindrada, 2 cilindros e 4 válvulas por cilindro. Na sua versão original o motor é naturalmente aspirado e alimentado com gasolina, sendo que os valores de potência máxima e torque máximo declarados pelo fabricante são, respectivamente, 42 cv e 3,02 kg.f.m. O aumento da potência e do torque desse motor foi obtido pela utilização de um turbocompressor com intercooler e pela substituição da gasolina pelo etanol. Tais modificações foram feitas observando-se uma limitação estabelecida nas regras da competição Fórmula SAE, segundo a qual o ar de admissão deve passar por uma garganta de $19 \mathrm{~mm}$ de diâmetro, restringindo, assim, a quantidade máxima de ar que pode ser admitida. Após as modificações o motor foi recalibrado usando o sistema de injeção eletrônica programável Megasquirt MS2 para, então, ser montado em um veículo experimental, o qual foi submetido a ensaios em um dinamômetro de rolo. Além disso, foi construído um modelo computacional usando o software Ricardo Wave, o que permitiu simular o funcionamento do motor antes e depois das modificações. Os resultados das simulações foram comparados com resultados experimentais, o que permitiu validar os resultados da simulação e verificar que os ganhos de potência e torque atingiram valores da ordem de $70 \%$ nos seus valores de pico.

Palavras-chave: Motores de combustão interna, Turboalimentação, Downsizing, Etanol combustível. 


\begin{abstract}
The present work describes the performance and efficiency improvement achieved in an engine that will be used in the Formula SAE competition. It is an engine manufactured by the Yamaha company, with $320 \mathrm{cc}$ of displacement, 2 cylinders and 4 valves per cylinder. In its original version, the engine is naturally aspirated and fueled with gasoline, and the maximum power and maximum torque values declared by the manufacturer are, respectively, $42 \mathrm{hp}$ and $3.02 \mathrm{~kg} . \mathrm{f} . \mathrm{m}$. The increase in power and torque of this engine was obtained by using a turbocharger with an intercooler and by replacing gasoline with ethanol. Such modifications were made observing a limitation established in the Formula SAE competition rules, according to which the intake air must pass through a $19 \mathrm{~mm}$ diameter throat, thus restricting the maximum amount of air that can be admitted. After the modifications, the engine was recalibrated using the Megasquirt MS2 programmable electronic injection system to then be mounted on an experimental vehicle, which was subjected to tests in a roller dynamometer. In addition, a computational model was built using the Ricardo Wave software, which allowed simulating the functioning of the engine before and after the modifications. The simulation results were compared with experimental results, which allowed validating the simulation results and verifying that the power and torque gains reached values in the order of $70 \%$ at their peak values.

Key-words: Internal Combustion Engines, Turbocharging, Downsizing, Ethanol fuel.
\end{abstract}




\section{LISTA DE FIGURAS}

FIGURA 1 - PRESSÃO NO CILINDRO DE UM MOTOR NATURALMENTE ASPIRADO E COM TURBOCOMPRESSOR.

FIGURA 2 - TORQUE DE UM MOTOR NATURALMENTE ASPIRADO E COM TURBOCOMPRESSOR.

FIGURA 3 - DISPOSIÇÃO DO RESTRITOR DE AR EM UM MOTOR NATURALMENTE ASPIRADO.

FIGURA 4 - DISPOSIÇÃO DO RESTRITOR DE AR EM UM MOTOR SOBREALIMENTADO.

FIGURA 5 - SISTEMA TURBOCOMPRESSOR COM INTERCOOLER. .15

FIGURA 6 - EIXO ROTOR DO TURBOCOMPRESSOR. .16

FIGURA 7 - LUBRIFICAÇÃO DO TURBOCOMPRESSOR. 17

FIGURA 8 - ROTOR DO COMPRESSOR DO TURBO IHI. .17

FIGURA 9 - ROTOR DA TURBINA DO TURBO IHI 18

FIGURA 10 - DESTAQUE DA VÁLVULA WASTEGATE. 19

FIGURA 11 - TURBO DE GEOMETRIA VARIÁVEL HOLSET HE500VE. 20

FIGURA 12 - ABERTURA DAS ALETAS CONFORME ROTAÇÃO. .21

FIGURA 13 - DEFINIÇÃO DA RAZÃO A/R. .22

FIGURA 14 - EFEITOS DA RAZÃO A/R. .22

FIGURA 15 - DIÂMETROS MÁXIMO E MÍNIMO DOS ROTORES DE UM TURBOCOMPRESSOR, MEDIDOS PARA A DETERMINAÇÃO DO TRIM. .23 FIGURA 16 - DIAGRAMA DE FUNCIONAMENTO DE UMA VÁLVULA WASTEGATE. .24

FIGURA 17 - DIAGRAMA DE UM ATUADOR PARA A WASTEGATE. .25

FIGURA 18 - MAPA DE EFICIÊNCIA DO COMPRESSOR. .26

FIGURA 19 - INTERCOOLER INSTALADO NO MOTOR. .28

FIGURA 20 - DETALHE DO INTERCOOLER: PLENUM. .29

FIGURA 21 - DETALHES DO INTERCOOLER. .29 FIGURA 22 - INTEGRAÇÃO ENTRE INTERCOOLER E CORPO DE BORBOLETA. 
FIGURA 23 - INFLUÊNCIA DO FATOR LAMBDA NOS PARÂMETROS DE DESEMPENHO (A) E NOS NÍVEIS DE EMISSÕES (B)........................................ FIGURA 24 - VARIAÇÃO DO PONTO DE AVANÇO DE IGNIÇÃO DE ACORDO COM A ROTAÇÃO DO MOTOR. 36

FIGURA 25 - COMPORTAMENTO DA PRESSÃO DO MOTOR DE ACORDO COM O ÂNGULO DE AVANÇO DE IGNIÇÃO. 37

FIGURA 26 - COMANDO DE VÁLVULAS YAMAHA R3. 39

FIGURA 27 - COMANDO DE VÁLVULAS SITUADO NO BLOCO. .40

FIGURA 28 - COMANDO DE VÁLVULAS E VIRABREQUIM. 41

FIGURA 29 - GEOMETRIA DO RESSALTO DO COMANDO DE VÁLVULAS. .42

FIGURA 30 - FASES DE UM COMANDO DE VÁLVULAS. .43

FIGURA 31 - DIAGRAMA DE TEMPOS DE VÁLVULAS. .46

FIGURA 32 - DIAGRAMA DE TEMPOS - ÂNGULOS DO VIRABREQUIM. .47

FIGURA 33 - EFEITO DA SOBREPOSIÇÃO EM ALTA VELOCIDADE. 49 FIGURA 34 - EFEITO DO ATRASO DO FECHAMENTO DA VÁLVULA DE ADMISSÃO EM ALTAS VELOCIDADES.

FIGURA 35 - EMISSÃO DE GASES PARA A ATMOSFERA EM FUNÇÃO DA SOBREPOSIÇÃO. .53

FIGURA 36 - DIAGRAMA DE TEMPOS PARA DIVERSOS MOTORES. .54

FIGURA 37 - FIXAÇÃO DO PROTÓTIPO NO DINAMÔMETRO. .59 FIGURA 38 - CALIBRAÇÃO DO SISTEMA DE INJEÇÃO E IGNIÇÃO DO PROTÓTIPO.

FIGURA 39 - CALIBRAÇÃO DO SISTEMA DE INJEÇÃO E IGNIÇÃO DO PROTÓTIPO. 60

FIGURA 40 - TESTE NO DINAMÔMETRO. 61

FIGURA 41 - LAYOUT GERAL DO MOTOR DA R3 SEM RESTRITOR NO SOFTWARE RICARDO WAVE. 63

FIGURA 42 - DADOS DO CILINDRO NO SOFTWARE RICARDO WAVE. .64

FIGURA 43 - DADOS DO MOTOR SEM RESTRITOR NO DINAMÔMETRO. .65 FIGURA 44 - DADOS COMPUTACIONAIS DO MOTOR SEM RESTRITOR SIMULADO NO SOFTWARE RICARDO WAVE. .66

FIGURA 45 - DADOS DO RESTRITOR NO SOFTWARE RICARDO WAVE. .67 
FIGURA 46 - DADOS COMPUTACIONAIS DO MOTOR SOBREALIMENTADO SIMULADO NO WAVE.

FIGURA 47 - CURVAS DE POTÊNCIA DO MOTOR ORIGINAL NATURALMENTE ASPIRADO SIMULADAS VIA SOFTWARE RICARDO WAVE E AFERIDO NO DINAMÔMETRO.FONTE: ELABORAÇÃO PRÓPRIA.

FIGURA 48 - CURVAS DE TORQUE DO MOTOR ORIGINAL NATURALMENTE ASPIRADO SIMULADAS VIA SOFTWARE E AFERIDO NO DINAMÔMETRO.FONTE: ELABORAÇÃO PRÓPRIA. .................................... 71 FIGURA 49 - COEFICIENTE DA DIFERENÇA DE POTÊNCIA ENTRE REAL E SIMULADO.FONTE: ELABORAÇÃO PRÓPRIA.

FIGURA 50 - CURVAS DE POTÊNCIA NO DINAMÔMETRO COM O MOTOR NATURALMENTE ASPIRADO NA MOTO YAMAHA R3 E NO CARRO (SEM RESTRITOR). .73

FIGURA 51 - CURVAS DE TORQUE NO DINAMÔMETRO COM O MOTOR NATURALMENTE ASPIRADO NA MOTO YAMAHA R3 E NO CARRO (SEM RESTRITOR).

FIGURA 52 - CURVAS DE POTÊNCIA AFERIDAS NO DINAMÔMETRO COM O MOTOR NATURALMENTE ASPIRADO NO CARRO (COM E SEM RESTRITOR).. 75 FIGURA 53 - CURVAS DE TORQUE AFERIDAS NO DINAMÔMETRO COM O MOTOR NATURALMENTE ASPIRADO NO CARRO (COM E SEM RESTRITOR). FONTE: ELABORAÇÃO PRÓPRIA. .75

FIGURA 54 - CURVAS DE POTÊNCIA E TORQUE COM MOTOR SOBREALIMENTADO COM E SEM RESTRITOR RESULTANTES DA SIMULAÇÃO.

FIGURA 55 - MAPA DO COMPRESSOR MOSTRANDO OS REGIMES DE TRABALHO NAS CONDIÇÕES SEM RESTRITOR(SEM CONTORNO) E COM RESTRITOR (COM CONTORNO AZUL). .77

FIGURA 56 - DIÂMETRO TEÓRICO DA WASTEGATE COM RESTRITOR E SEM RESTRITOR NO SOFTWARE RICARDO WAVE. .78 FIGURA 57 - CURVAS DE TORQUE COM MOTOR SOBREALIMENTADO SEM RESTRITOR E MOTOR NATURALMENTE ASPIRADO, AFERIDOS NO DINAMÔMETRO. .79 
FIGURA 58 - CURVAS DE POTÊNCIA COM MOTOR SOBREALIMENTADO SEM RESTRITOR E MOTOR NATURALMENTE ASPIRADO, AFERIDOS NO

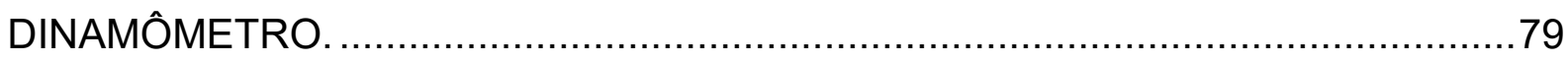
FIGURA 59 - CURVAS DE TORQUE COM MOTOR SOBREALIMENTADO SEM RESTRITOR E MOTOR NATURALMENTE ASPIRADO SEM RESTRITOR COMPARADOS ENTRE SOFTWARE DE SIMULAÇÃO E DINAMÔMETRO............80 FIGURA 60 - CURVAS DE POTÊNCIA COM MOTOR SOBREALIMENTADO SEM RESTRITOR E MOTOR NATURALMENTE ASPIRADO SEM RESTRITOR, COMPARADO ENTRE SOFTWARE DE SIMULAÇÃO E DINAMÔMETRO ..............81 


\section{LISTA DE TABELAS}

TABELA 1 - OCTANAGEM DE COMBUSTIVVEIS NO BRASIL. 32 TABELA 2 - PARÂMETROS TÍPICOS DE MOTORES CICLO DIESEL E IGNIÇÃO POR CENTELHA. .55

TABELA 3 - CONDIÇÕES DE TESTES NO DINAMÔMETRO. .58 TABELA 4 - DADOS UTILIZADOS NAS SIMULAÇÕES NO SOFTWARE RICARDO WAVE. .62 
SUMÁRIO

1 INTRODUÇÃO

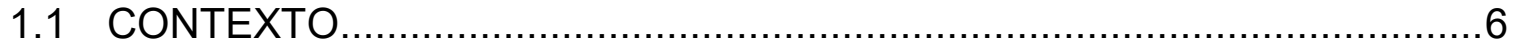

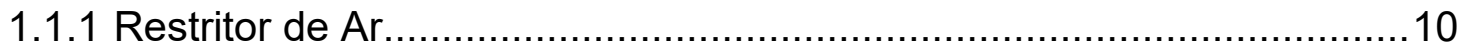

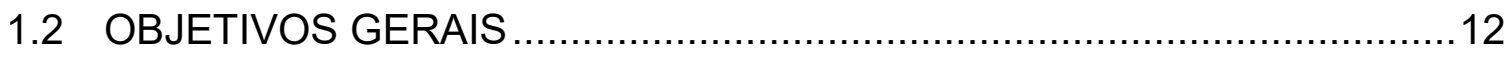

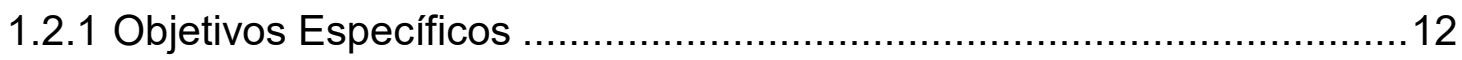

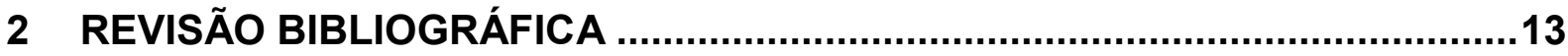

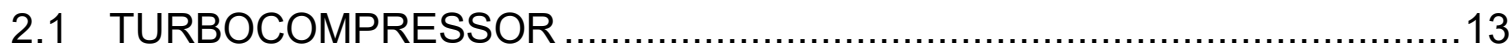

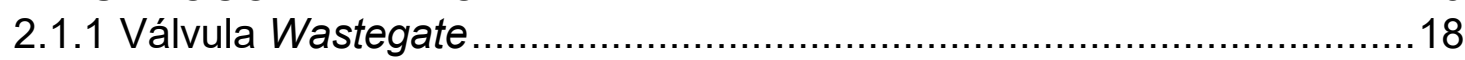

2.1.2 Turbocompressor de Geometria Variável .........................................19

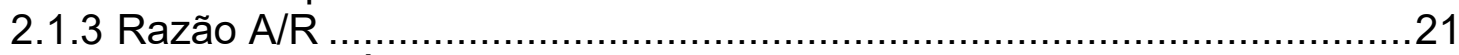

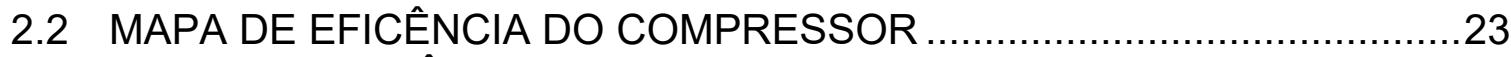

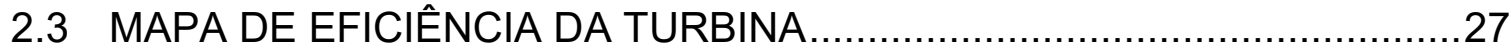

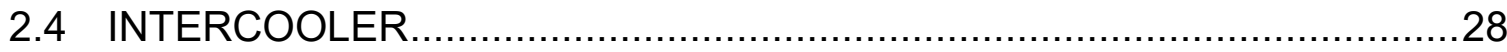

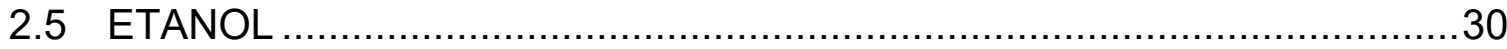

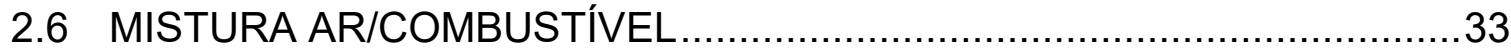

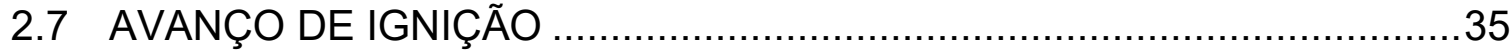

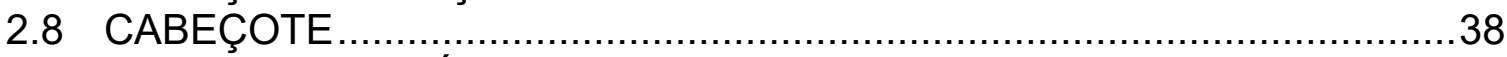

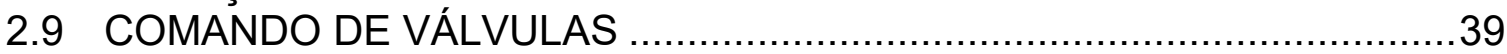

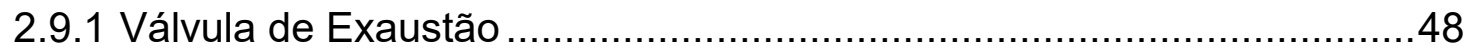

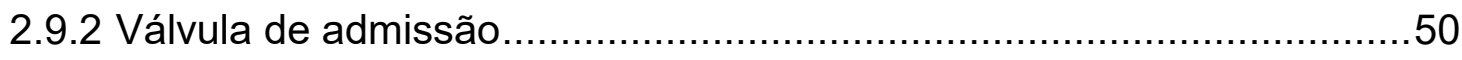

2.9.3 Limitações para a Sobreposição das Válvulas ...................................51

2.9.4 Tempos de Válvulas para Diferentes Aplicações...................................53

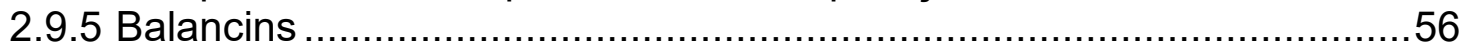

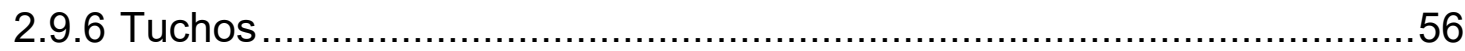

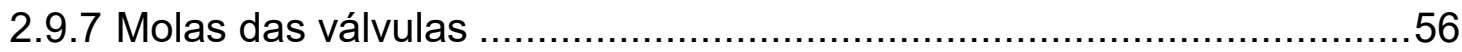

3 METODOLOGIA

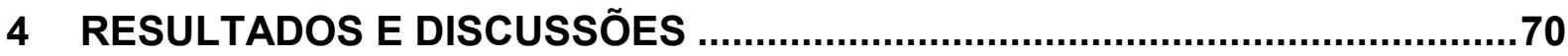

5 CONCLUSÕES

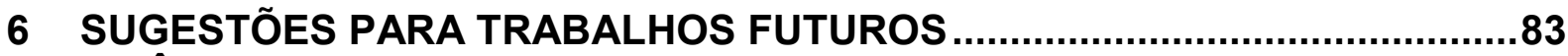

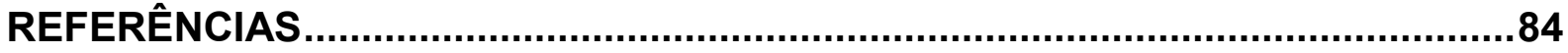




\section{INTRODUÇÃO}

\subsection{CONTEXTO}

Motores de combustão interna são máquinas nas quais energia química é convertida em energia térmica por meio da combustão de uma mistura de ar e combustível e parte desta energia é transformada em energia mecânica (GANESAN, 1995; BASSHUYSEN; SHAFER, 2006).

O propósito de um motor de combustão interna é a produção de potência mecânica vinda da energia química contida no combustível. Essa energia é liberada pela queima do combustível dentro do motor (HEYWOOD, 1988).

Com o avanço da tecnologia automotiva que trouxe a popularização dos motores sobrealimentados, os motores de ignição por faísca vêm sofrendo uma grande transformação que possibilita a obtenção de um melhor rendimento e menor emissão de poluentes quando comparado com os motores naturalmente aspirados. Atualmente os fabricantes de automóveis buscam produzir motores menores com alta performance e baixo consumo de combustível, uma tendência conhecida como downsizing, o termo no setor automotivo representa um motor com capacidade cúbica menor, porém com desempenho e torque semelhantes a um motor de capacidade cúbica maior.

Para isso, são empregadas soluções tecnológicas que visam o aumento de eficiência energética (PIELECHA, 2014), reduzindo o consumo de combustível e a emissão de gases poluentes. As tecnologias aplicadas pelos fabricantes são geralmente o uso do turbocompressor acompanhado da injeção direta de combustível.

Conforme apontado por (GOUZONNAT, 2015), a redução do tamanho físico dos motores faz com que também os veículos fiquem mais leves, já que o propulsor é um dos itens de maior peso no veículo, assim se tem acelerações melhores e um melhor comportamento dinâmico do veículo.

Segundo Patil et al. (2017), o downsizing consiste no uso de um motor menor em um veículo e que forneça a potência de um motor maior por meio do uso 
de tecnologias recentes, esse termo geralmente se refere a motores de combustão interna que utilizam gasolina ou diesel. A redução do tamanho do motor é um conceito e tendência dos fabricantes de motores para fornecerem motores mais eficientes e potentes.

Turner et al. (2016) definem o downsizing como uma abordagem comprovada para obter uma eficiência superior. Isto é obtido convencionalmente por um motor com volume menor, geralmente com um turbocompressor acionado pelos gases de exaustão.

Isenstadt et al. (2016) fizeram um estudo sobre o downsizing e as tendências tecnológicas para melhorar a eficiência e reduzir tanto o consumo de combustível como a emissão de poluentes dos motores a gasolina. Esses autores chamam a atenção para os esforços dos fabricantes de turbocompressores para reduzir o turbo lag, com novas tecnologias como por exemplo o E-boost da empresa BorgWarner, que com um motor elétrico acoplado no compressor do turbo, fornece pressão mais rapidamente.

Com o crescente aumento do preço dos combustíveis nas últimas décadas, e com uma possível escassez na oferta de petróleo em um período próximo e as novas políticas ambientais de diversos países (visando a redução de emissões de poluentes), essas tecnologias (turbocompressor e injeção direta de combustível) vêm sendo empregadas constantemente pelos fabricantes, na busca da melhor eficiência energética nos motores de combustão interna.

O downsizing acabou chegando no esporte automotivo também, na Fórmula 1, que até 2013 utilizava motor V8 2.4 litros, naturalmente aspirados com 750 cv de potência e com capacidade do tanque de combustível de $140 \mathrm{~kg}$, na temporada de 2014 teve a mudança para o motor V6 1.6 litros com turbocompressor e rendia os mesmos $750 \mathrm{cv}$ de potência, mas com capacidade do tanque de combustível reduzida para $100 \mathrm{~kg}$, visando uma economia enorme de combustível na temporada.

A fabricante Volkswagen também resolveu apostar no downsizing no Brasil, no seu modelo Jetta. O motor 2.0 litros aspirado, que rendia $116 \mathrm{cv}$ de potência com $17,7 \mathrm{kgfm}$ de torque à $4000 \mathrm{rpm}$ e consumo de $8,8 \mathrm{~km} / \mathrm{l}$ na cidade e 10,8 km/l na rodovia utilizando gasolina, foi substituído pelo motor 1.4 TSI que utiliza injeção direta e turbocompressor, rende $150 \mathrm{cv}$ de potência com 25,5 kgfm à $1500 \mathrm{rpm}$ e consumo de $10,4 \mathrm{~km} / \mathrm{l}$ na cidade e $13,8 \mathrm{~km} / \mathrm{l}$ na rodovia utilizando gasolina. Assim, 
passou a utilizar um motor menor, mas com maior potência e menor consumo e, ainda, com uma curva de torque que alcança maiores valores em baixas rotações. Outros fabricantes também realizaram substituições de motores parecidas, com o objetivo de reduzir o consumo de combustível e a emissão de poluentes.

Para aumentar a pressão de admissão e, consequentemente, a massa de ar admitida no motor, surgiram os motores sobrealimentados (BRUNETTI, 2012). Nesses motores existem dispositivos que elevam a pressão no coletor de admissão acima da pressão atmosférica. Um desses dispositivos, largamente utilizado hoje pelos fabricantes de motores, é o turbocompressor, que utiliza os gases de escapamento para gerar trabalho numa turbina acionando o compressor, que por sua vez aumenta a pressão no coletor de admissão, (BRUNETTI, 2012). Bell (1997) ressalta que a sobrealimentação é uma forma eficiente de se aumentar a pressão no cilindro, possibilitando que o torque e a potência sejam ampliados (Figuras 1 e 2).

Figura 1 - Pressão no cilindro de um motor naturalmente aspirado e com turbocompressor.

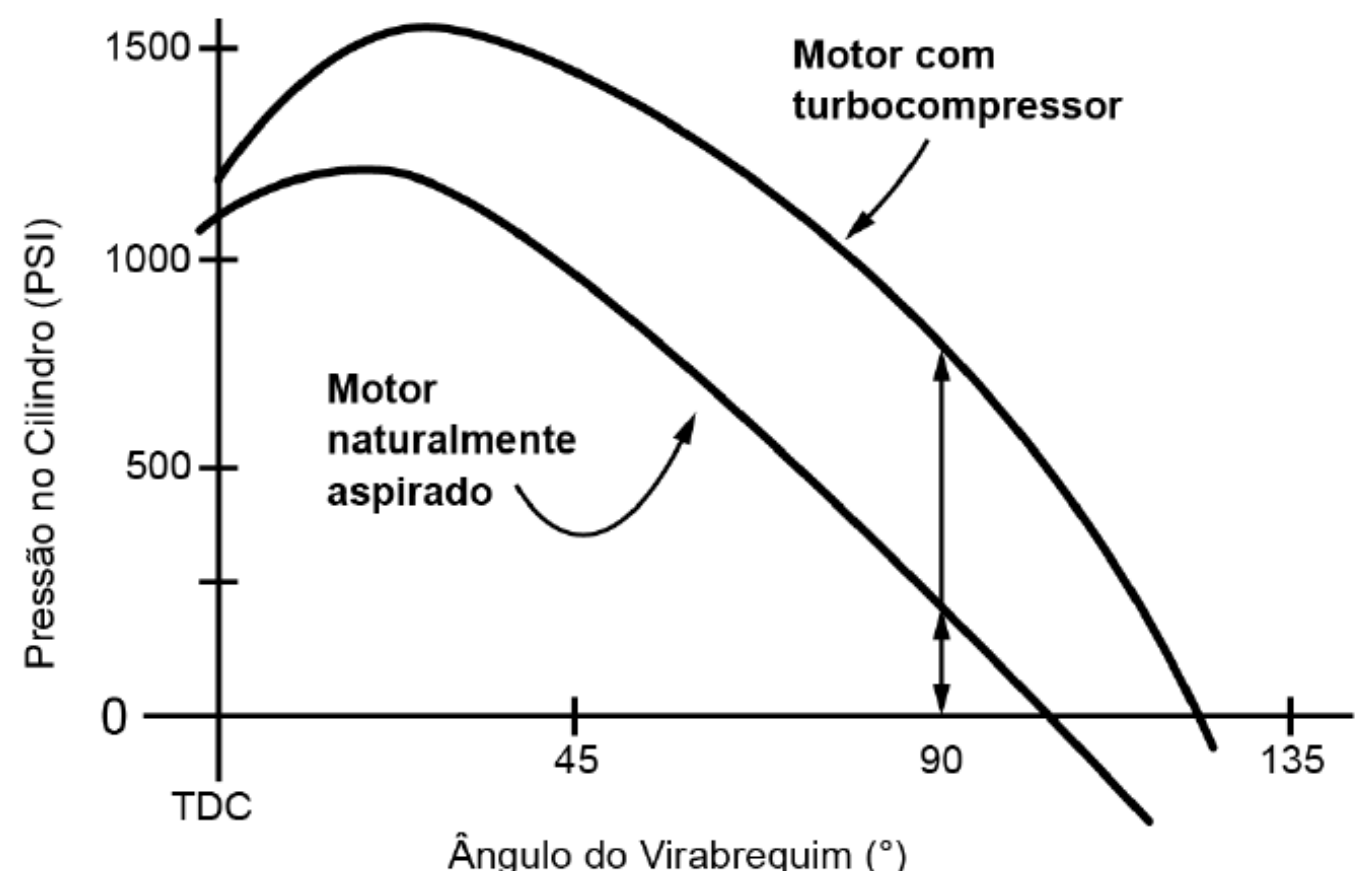

Fonte: Adaptado de Bell (1997). 
Figura 2 - Torque de um motor naturalmente aspirado e com turbocompressor.

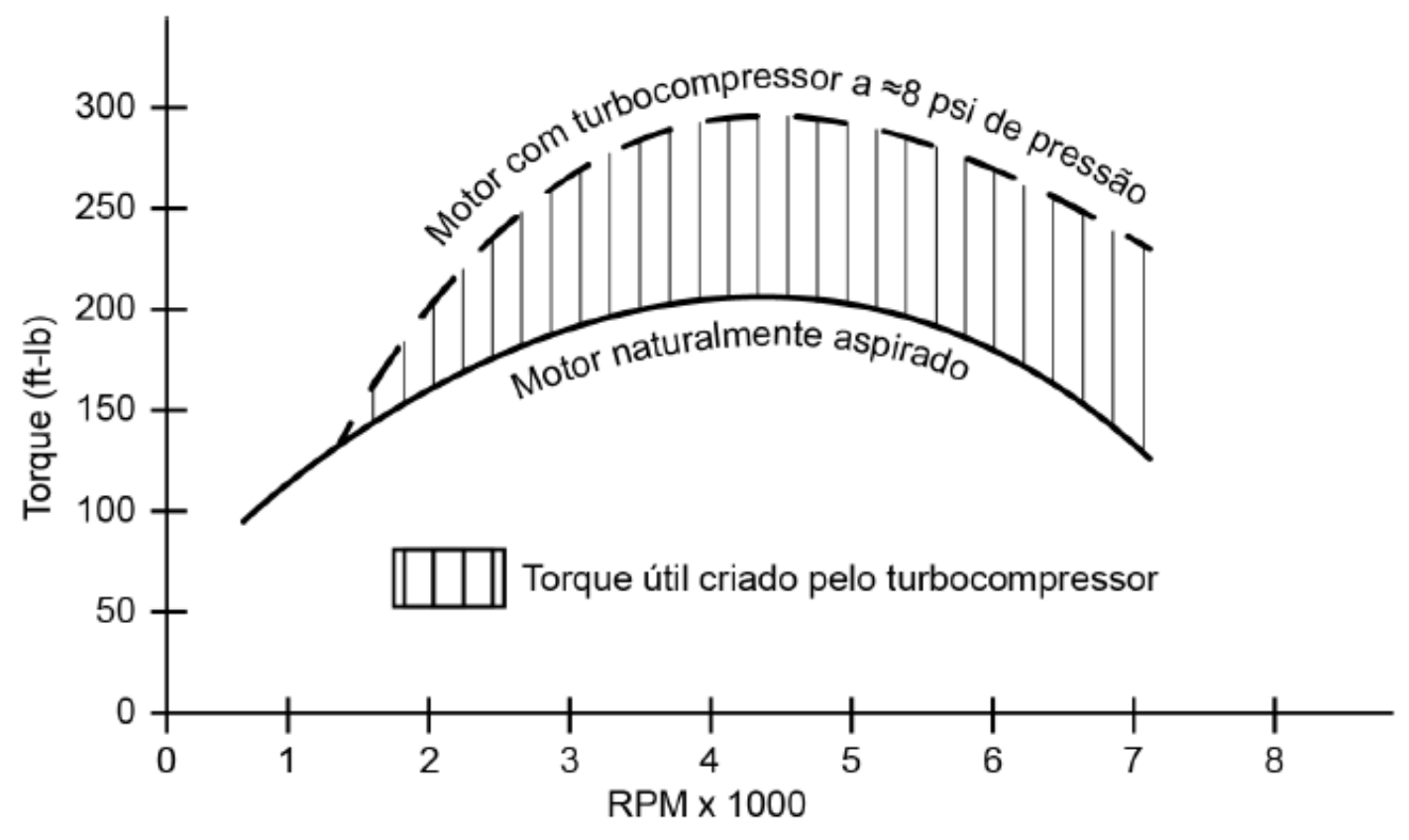

Fonte: Adaptado de Bell (1997)

A qualidade do combustível é fundamental para o funcionamento de motores sobrealimentados, sendo que a octanagem do combustível e a velocidade da queima, são características que influenciam a ocorrência da detonação no motor (BELL, 1997).

Ricardo (1931) concluiu em seus estudos que quanto maior a compressão dinâmica proporcionada pelo turbocompressor, maior a necessidade de utilizar combustíveis de alta octanagem. Por isso, no presente trabalho optou-se pela utilização do etanol.

Os motores turboalimentados apresentam valores de torque máximo em rotações mais baixas em comparação com os motores naturalmente aspirados. Essa característica torna os motores turbo mais eficientes do que os motores aspirados, pois eles disponibilizam o torque máximo em rotações mais baixas (1400 rpm para o Jetta 1.4 turbo), enquanto que no motor aspirado esse torque máximo só está disponível em rotações mais elevadas (4000 rpm para o Jetta 2.0 aspirado). Esse fator contribui para a redução do consumo de combustível (uma das principais metas 
do downsizing), uma vez que o motor pode se manter em baixas rotações com alto torque, por consequência consumindo menos combustível, dessa forma o motorista precisa acelerar menos, pois o torque já está disponível a baixas rotações, economizando combustível (AHMED et al., 2018).

Golloch (2006) chama a atenção para um aspecto do downsizing que pode levar à perda de mercado nos segmentos de modelos esportivos e de outros veículos destinados a clientes com maior poder aquisitivo. Nesses casos, um motor de menor volume no cofre do veículo e as variações de acústica do motor, decorrentes da operação em rotações mais baixas, podem causar uma impressão desfavorável para a comercialização.

\subsubsection{Restritor de Ar}

O motor que é objeto de estudo neste trabalho destina-se a competição denominada Fórmula SAE. As regras dessa competição estabelecem que pode ser utilizado qualquer motor com volume deslocado de até $710 \mathrm{~cm}^{3}$, alimentado com gasolina ou etanol.

Para limitar a capacidade de potência do motor, pela regra da competição, é necessário utilizar um restritor de ar circular instalado no sistema de admissão, e todo o escoamento de ar deve primeiro passar por ele. O sistema pode ser visto nas Figuras 3 e 4, para os casos de motor aspirado e turboalimentado, respectivamente. 
Figura 3 - Disposição do restritor de ar em um motor naturalmente aspirado.

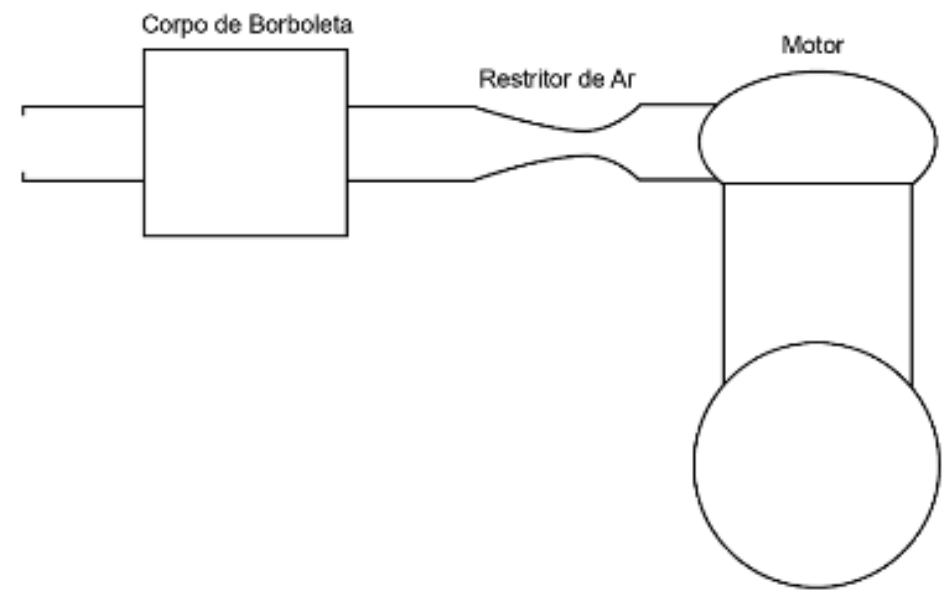

Fonte: Adaptado do regulamento da competição Fórmula SAE. Disponivel em: <https://www.fsaeonline.com/cdsweb/gen/DownloadDocument.aspx?DocumentID=6 4b861c2-980a-40fc-aa88-6a80c43a8540>. Acesso em: 17 out. 2019.

Figura 4 - Disposição do restritor de ar em um motor sobrealimentado.

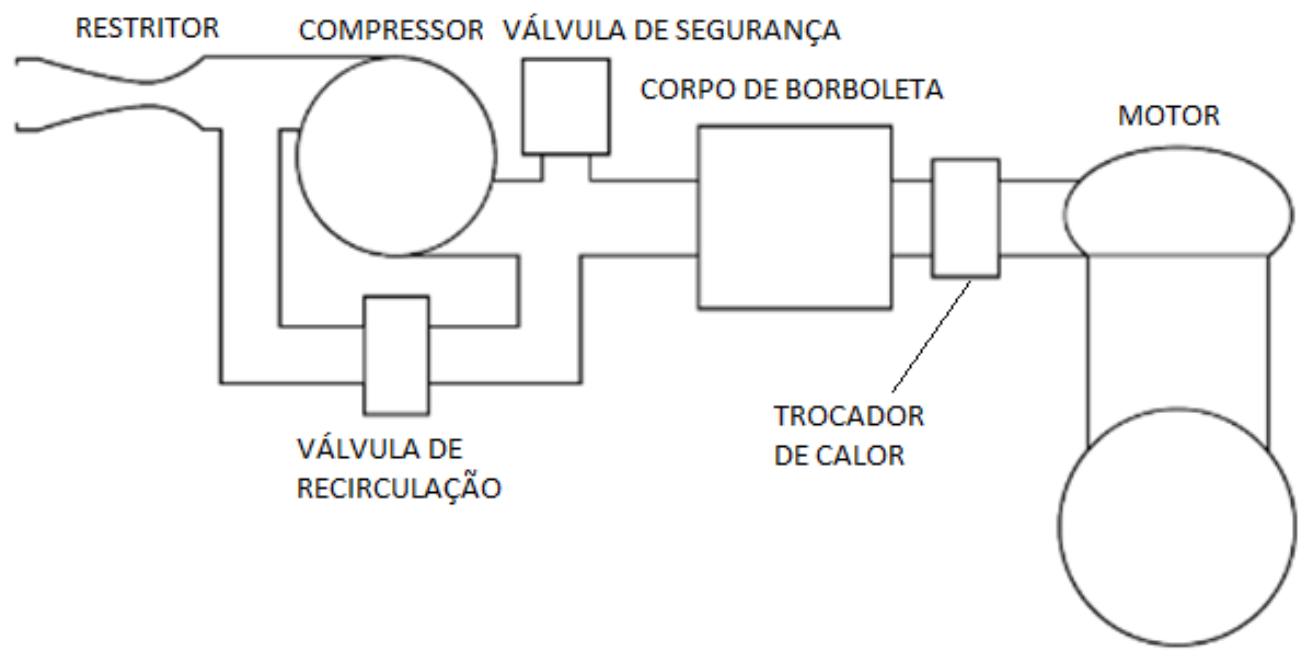

Fonte: Adaptado de regulamento da competição Fórmula SAE. Disponivel em: <https://www.fsaeonline.com/cdsweb/gen/DownloadDocument.aspx?DocumentID=6 4b861c2-980a-40fc-aa88-6a80c43a8540>. Acesso em: 17 out. 2019. 


\subsection{OBJETIVOS GERAIS}

No presente trabalho, será apresentada a aplicação de uma dessas soluções tecnológicas no motor: a adição de um turbocompressor com intercooler. $\mathrm{O}$ motor será calibrado com o combustível etanol através de uma injeção eletrônica programável comercial Megasquirt MS2. Finalmente, com base no desempenho avaliado em dinamômetro de rolo, será feita uma comparação entre o motor original (a gasolina e naturalmente aspirado) e a versão modificada (a etanol e com turbocompressor). Esses resultados também serão comparados com um modelo de simulação feito no software Ricardo Wave.

\subsubsection{Objetivos Específicos}

A fim de alcançar os objetivos gerais, têm-se os seguintes objetivos específicos:

1- Caracterização de um motor de combustão interna de injeção indireta downsizing movido puramente a etanol;

2 - Instalação de um turbocompressor compatível com o motor em estudo;

3 - Calibração do motor através de uma injeção programável;

4 - Testes em dinamômetro de rolo para comparar os ganhos obtidos;

5 - Realizar uma simulação computacional usando o software Ricardo Wave e comparar os resultados com os experimentais;

6 - Verificar quais efeitos o restritor de ar traz no motor em estudo. 


\section{REVISÃo BIBLIOGRÁFICA}

\section{$2.1 \quad$ TURBOCOMPRESSOR}

Turbocompressores são descritos por Pulkrabek (2003) como conjuntos formados por uma turbina e um compressor, este último usado para aumentar a pressão do ar admitido no motor, resultando em uma maior massa de ar e combustível nos cilindros durante cada ciclo. $O$ ar e combustível adicionais resultam em uma maior quantidade de calor liberada durante a combustão e, consequentemente, em uma maior potência no eixo do motor. $O$ aumento de pressão varia entre 20 a $250 \mathrm{kPa}$, sendo mais comum que este valor fique próximo ao limite inferior desse intervalo.

A energia disponível no fluxo de gases de escape é usada para movimentar a turbina que, por sua vez, movimenta o compressor aumentado a massa específica do fluido admitido antes de entrar em cada cilindro (HEYWOOD, 1988).

A energia presente nos gases de escape não é aproveitada em um motor naturalmente aspirado. Por isso, o aproveitamento da energia dos gases de escape altera o balanço energético do motor, possibilitando o aumento de sua eficiência térmica (BRUNETTI, 2012).

O compressor não tem ligações mecânicas com o motor, não consumindo potência de seu eixo. O turbocompressor é uma máquina que opera em altas rotações, significativamente mais elevadas que as do motor. O rotor do compressor é ligado ao rotor da turbina por um eixo, suportado por um sistema de mancais ou rolamentos (nos dispositivos mais modernos). O sistema de mancais ou rolamentos, é montado na carcaça central, sendo constituído, normalmente, por mancais radiais flutuantes em filme de óleo, e pelo mancal axial ou mancal de encosto, também hidrodinâmico. O óleo lubrificante é exatamente o mesmo utilizado no motor, oriundo de sua galeria principal, que, após lubrificar e arrefecer o conjunto, retorna ao cárter pela ação da gravidade. No intuito de manter o óleo lubrificante dentro da carcaça central, evitando que atinja o rotor do compressor (e consequentemente o motor) ou o rotor da turbina (e, por sua vez, o sistema de exaustão), o turbocompressor conta com sistemas de vedação, em que, geralmente são utilizadas vedações dinâmicas 
associadas com anéis de pistão, que utilizam as pressões e rotações características da operação do turbocompressor para o correto funcionamento (BRUNETTI, 2012).

Atualmente, na indústria automotiva existem diversas opções para cada subsistema do turbocompressor, por exemplo, estágio de turbina de geometria variável, mancais de rolamentos, materiais para rotores com maior vida à fadiga ou de menor inércia, atuadores de controle comandados pelo módulo de controle eletrônico do motor, sistemas de dois estágios em diferentes arranjos, como, por exemplo, dois turbos em série ou paralelo, diretos ou sequênciais, usados em um único motor, entre outros.

Nos motores atuais, pode-se dizer que praticamente todos os motores sobrealimentados utilizam um resfriador de ar de admissão (intercooler) que pode ser do tipo ar/ar ou ar/água. O intercooler do tipo ar/ar é mais simples, precisa de altas velocidades do veículo para operar eficientemente, tem maior confiabilidade e menor manutenção e possui um custo menor. O intercooler do tipo ar/água opera eficientemente mesmo com o veículo em baixas velocidades, provoca menor perda de pressão do turbo e, com isso, melhor resposta, porém tem um custo mais alto por geralmente incluir um sistema de bombeamento próprio, utilizando uma bomba elétrica para o líquido de arrefecimento.

Durante o trabalho de compressão, ocorre um aumento de temperatura do ar, assim o intercooler reduz esta temperatura e aumenta a densidade do ar no coletor de admissão, e como consequência, aumenta a quantidade de ar que ingressa no cilindro do motor. O intercooler ajuda a reduzir as temperaturas do processo de combustão do motor e dos gases de escapamento, trazendo benefícios nas emissões de poluentes, além de uma melhor durabilidade do motor. A Figura 5 mostra como é o sistema de turbocompressor com o uso do intercooler. 
Figura 5 - Sistema Turbocompressor com Intercooler.

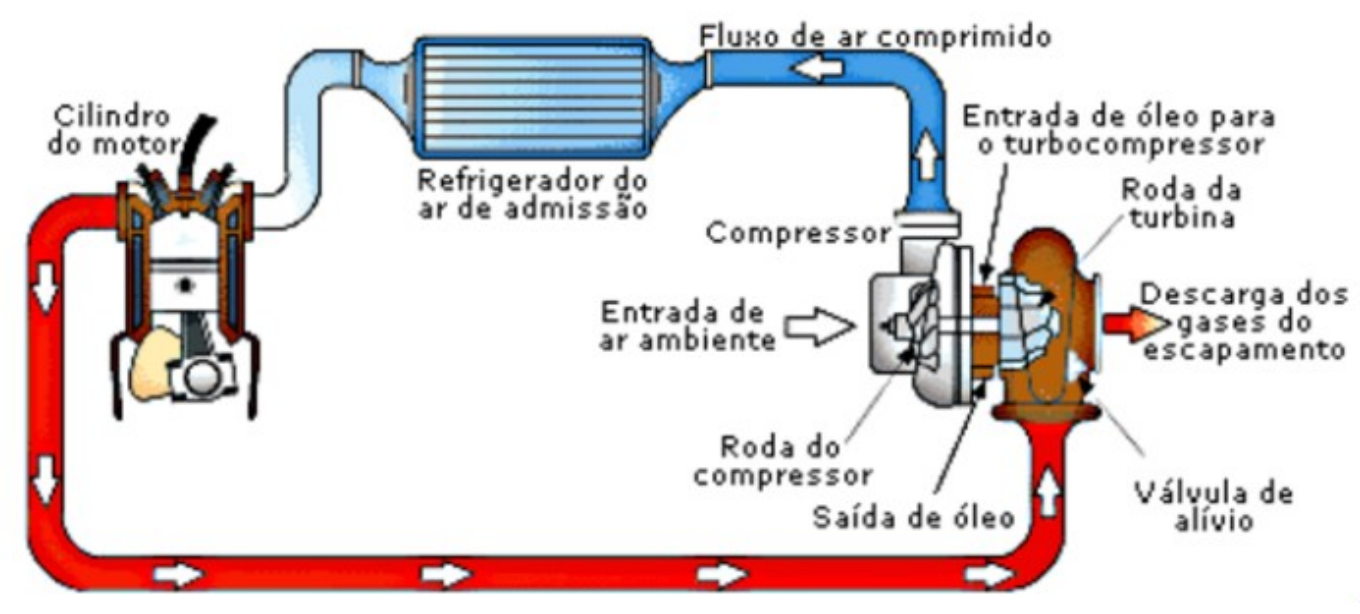

Fonte: Adaptado de Laino, 2014.

Os principais objetivos de utilização do turbocompressor em motores são:

a) Aumento de potência específica;

b) Aproveitamento da energia dos gases de exaustão;

c) Compensação da perda de potência devido a altitudes;

d) Redução na emissão de $\mathrm{CO}_{2}$;

e) Economia de combustível.

O turbocompressor tem a função de sobrealimentar o motor e, durante o funcionamento, o fluxo dos gases (com pressão, velocidade e temperatura) gerados na combustão sai pelos dutos de escapamento. O fluxo dos gases é direcionado para a carcaça da turbina e movimenta o rotor da turbina e o rotor do compressor (Figura 6) posicionados nas extremidades do mesmo eixo. O rotor compressor aspira o ar filtrado e o comprime na carcaça compressora para dentro da câmara de combustão. 
Figura 6 - Eixo rotor do turbocompressor.

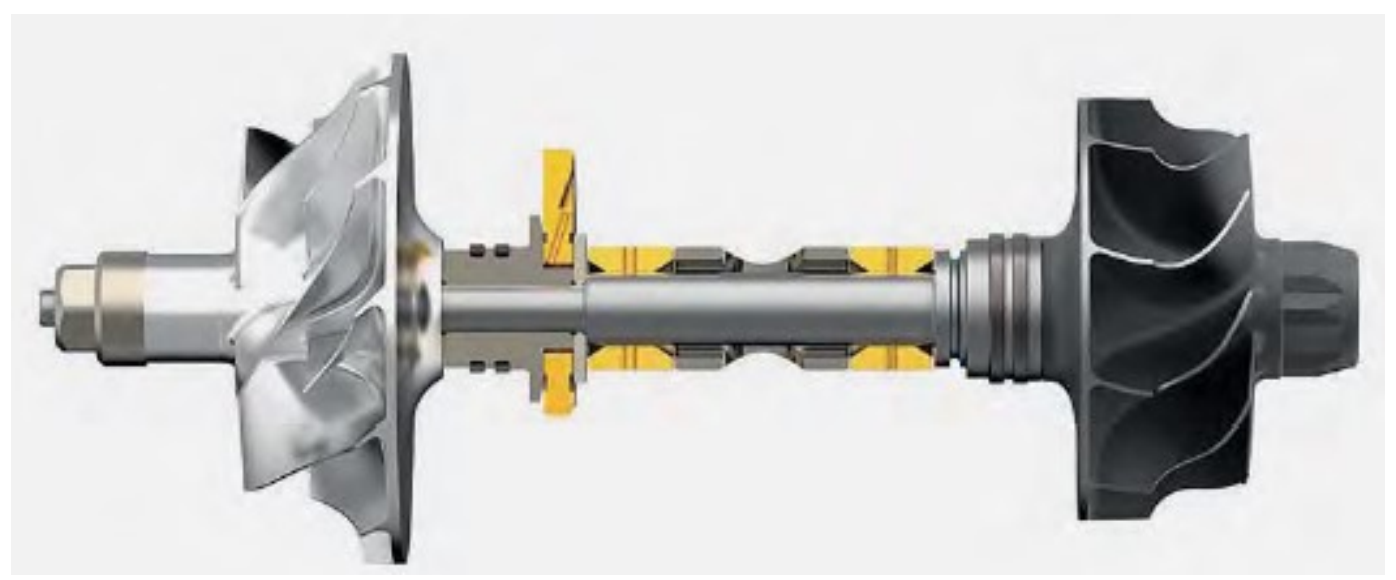

Fonte: Mahle.

O eixo é montado na carcaça central e sustentado por dois mancais flutuantes .

A lubrificação é realizada através de dutos que conduzem o óleo lubrificante para os mancais. O óleo lubrificante é o mesmo utilizado no motor, chega por meio de galerias alinhada com os furos dos mancais, promovendo a lubrificação e refrigeração do conjunto.

O óleo lubrificante retorna por gravidade para o cárter (Figura 7). Para evitar a contaminação do rotor da turbina, do compressor e da passagem de gases para a carcaça central, vedações são instaladas em cada lado do eixo entre o mancal radial e o rotor correspondente.

Para atender à demanda de novos motores de maior potência, mais econômicos e menos poluentes, foram desenvolvidos turbos com dispositivos para controlar a pressão e aumentar a potência em diferentes faixas de rotação. 
Figura 7 - Lubrificação do turbocompressor.

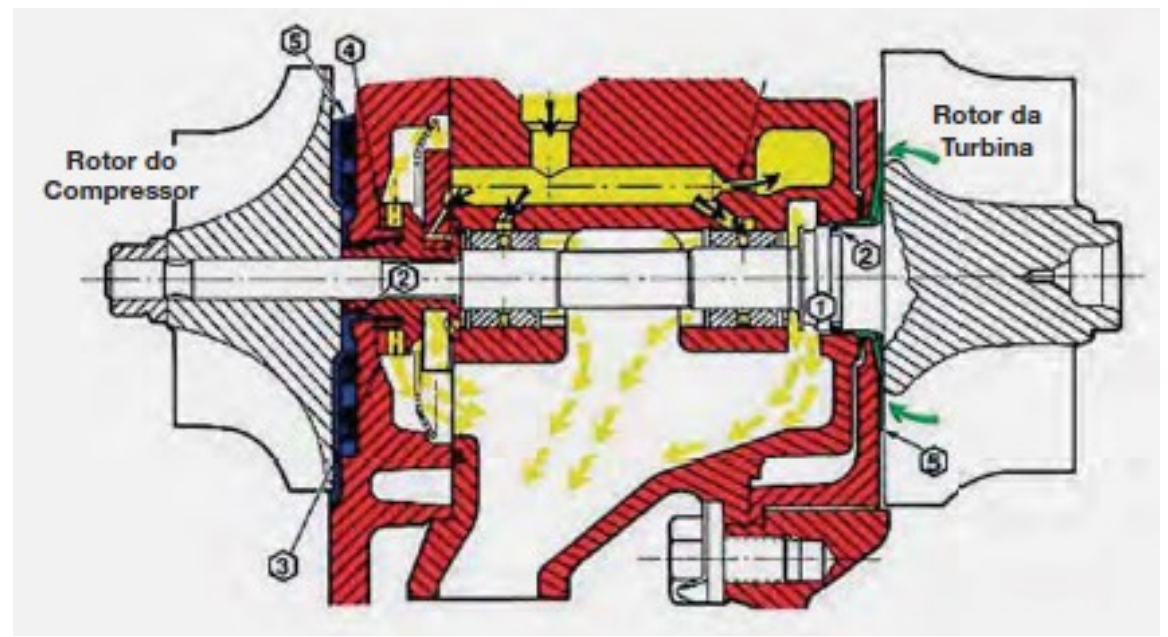

Fonte: Mahle.

Nas Figuras (8 e 9) têm-se, respectivamente, os rotores do compressor e da turbina do turbo $\mathrm{IHI}$ utilizado nesse trabalho.

Figura 8 - Rotor do compressor do turbo IHI.

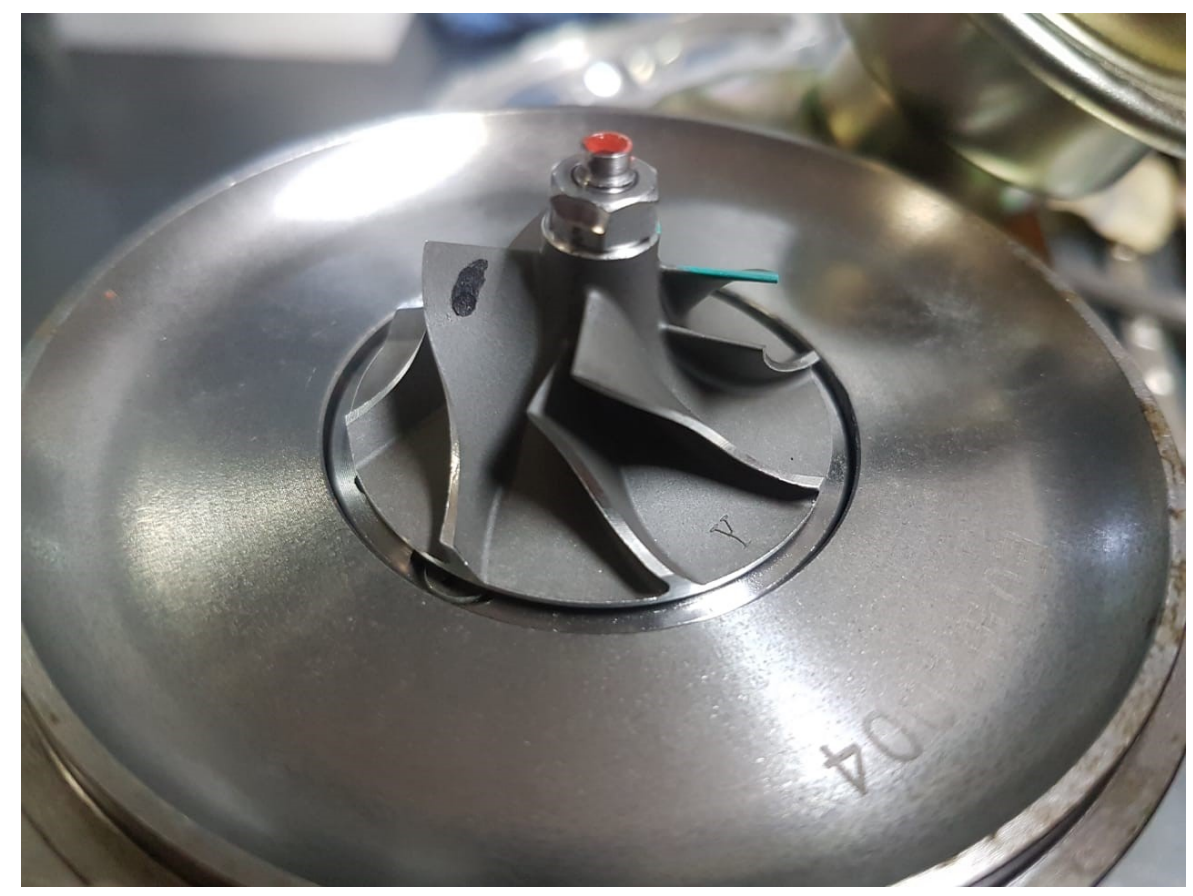

Fonte: Elaboração própria. 


\section{Figura 9 - Rotor da turbina do turbo IHI.}

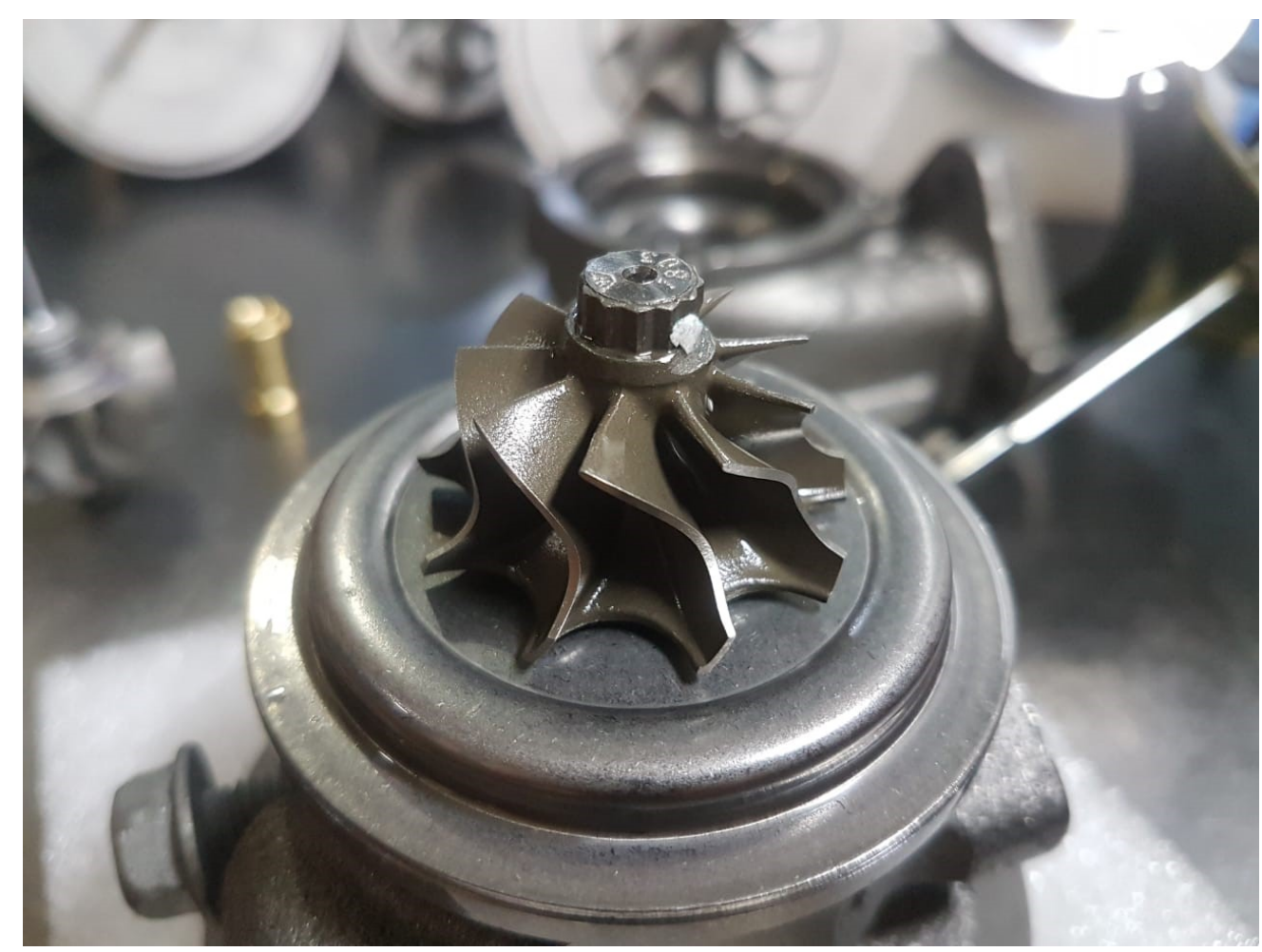

Fonte: Elaboração própria.

\subsubsection{Válvula Wastegate}

A válvula wastegate (Figura 10) tem função de regular a pressão de sobrealimentação, evitando danos ao turbo e ao motor, devendo ser calibrada para uma boa atuação no sistema.

A válvula atua aliviando a pressão do turbo e consequentemente a vazão de ar que vai para o motor, permitindo melhor combustão e desempenho, principalmente em baixas rotações, ou seja, reduzido a emissão de poluentes nessa faixa de rotação.

Se a regulagem for errada para menos, a válvula abre facilmente impedindo que se atinja a pressão de admissão desejada. Se for para mais, não abre na pressão desejada, ocasionando um aumento de pressão no compressor e na rotação do turbo. 
Figura 10 - Destaque da válvula wastegate.

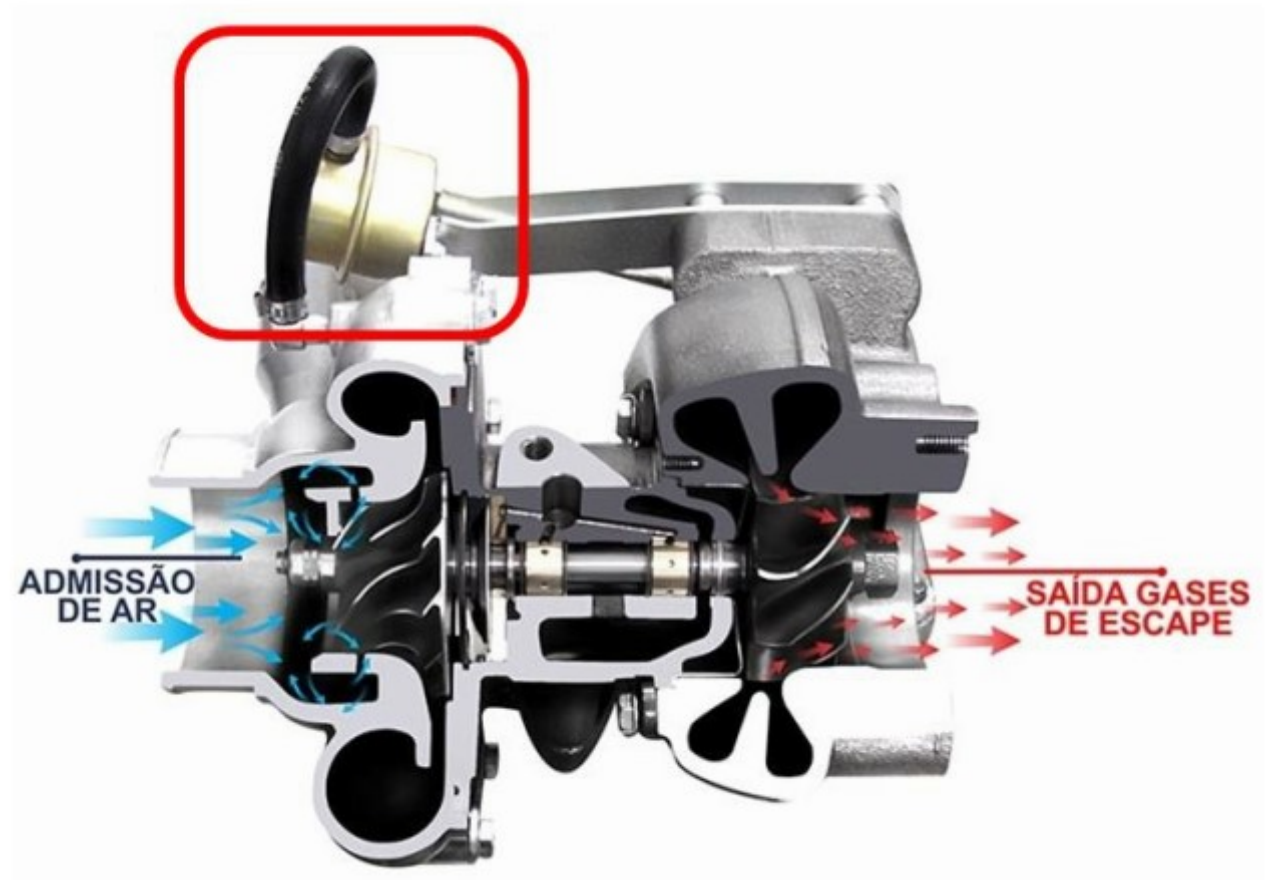

Fonte: Adaptado de curso EAD Biagio turbos, (2016).

\subsubsection{Turbocompressor de Geometria Variável}

O mecanismo de geometria variável da turbina regula a pressão do turbo pelo ajuste das palhetas, independentemente da velocidade do motor (Figuras $11 \mathrm{e}$ 12). As palhetas permitem alterar a área de passagem do escoamento de gases de exaustão e, com isso, provocam o aumento ou a diminuição da velocidade de escoamento. Aumentando-se a energia cinética do escoamento, aumenta-se também a velocidade de rotação do turbocompressor. 
Figura 11 - Turbo de geometria variável Holset HE500Ve.

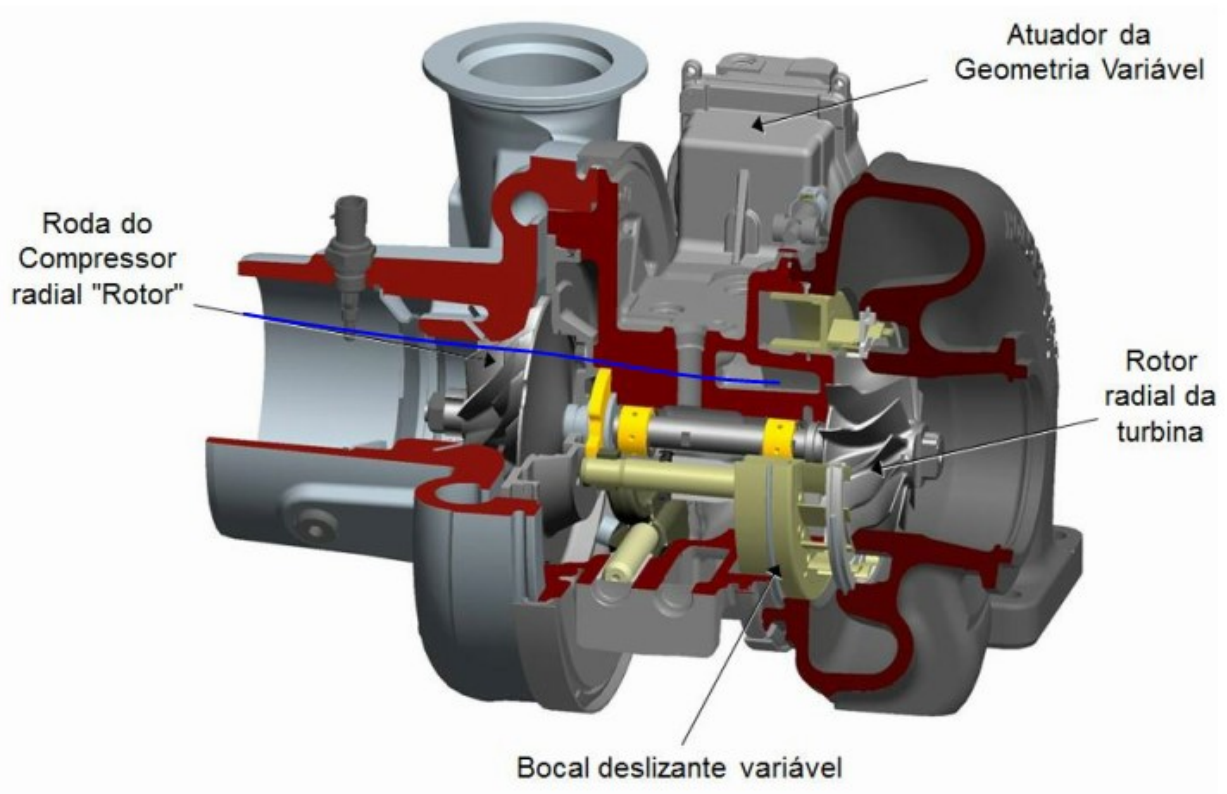

Fonte: Adaptado de Laino, (2014).

Os motores equipados com turbocompressores de geometria variável proporcionam mais suavidade no funcionamento do motor e melhor rendimento, entretanto, por serem mais complexos, são mais susceptíveis a problemas de confiabilidade. Suas pás internas necessitam de mais lubrificação e estão mais sujeitas ao desgaste. Por isso, em algumas aplicações, é preferível a utilização de dois turbocompressores diferentes, ao invés de um turbocompressor de geometria variável, na Figura 12 mostra-se a atuação das pás de geometria variável no fluxo de ar. 
Figura 12 - Abertura das aletas conforme rotação.

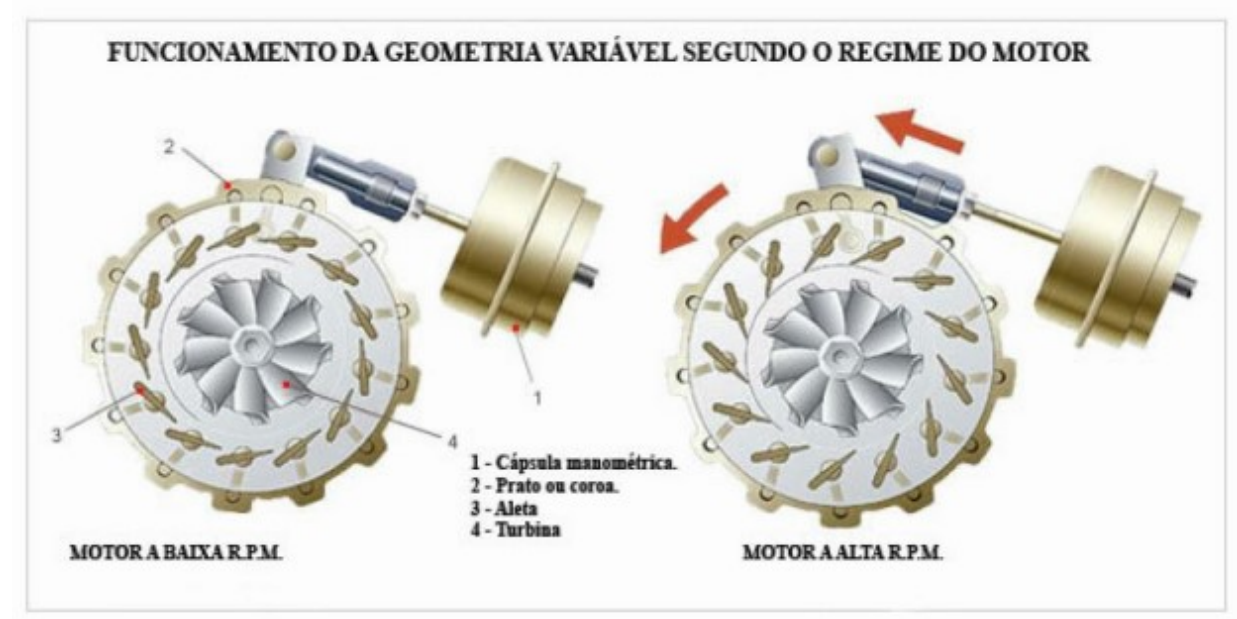

Fonte: Adaptado de Laino, (2014).

\subsubsection{Razão A/R}

Segundo Bell (1997), a razão de aspecto A/R (Área / Raio) descreve uma característica geométrica de todas as volutas de compressor e turbina. Este parâmetro expressa a razão entre a área da seção transversal da entrada (ou, para as carcaças do compressor, da descarga) e o raio medido a partir do eixo central até o centróide dessa área (ver Figuras 13 e 14).

Geralmente essa proporção é constante ao longo da voluta. As razões $A / R$ elevadas fazem com que o turbocompressor desempenhe bem em altas rotações e as razões $A / R$ baixas permitem melhores respostas em baixas rotações, porém podem fazer com que a vazão de gases seja prejudicada em altas rotações (Bell, 1997).

O trim é um termo utilizado para expressar a relação entre os quadrados dos diâmetros de entrada e de saída de um rotor (turbina ou compresso) Figura 15. O trim de um rotor, seja compressor ou turbina, afeta o desempenho alterando o fluxo de ar. 
Figura 13 - Definição da Razão A/R.

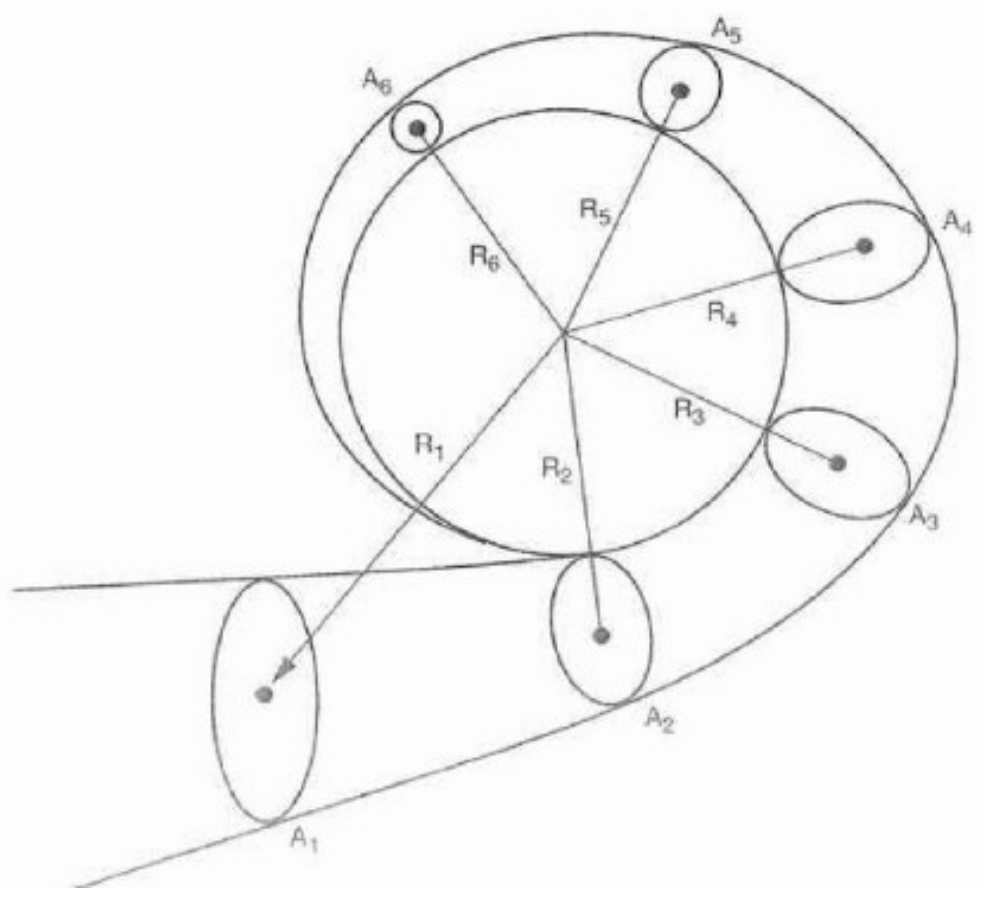

Fonte: Bell (1997).

Figura 14 - Efeitos da Razão A/R.

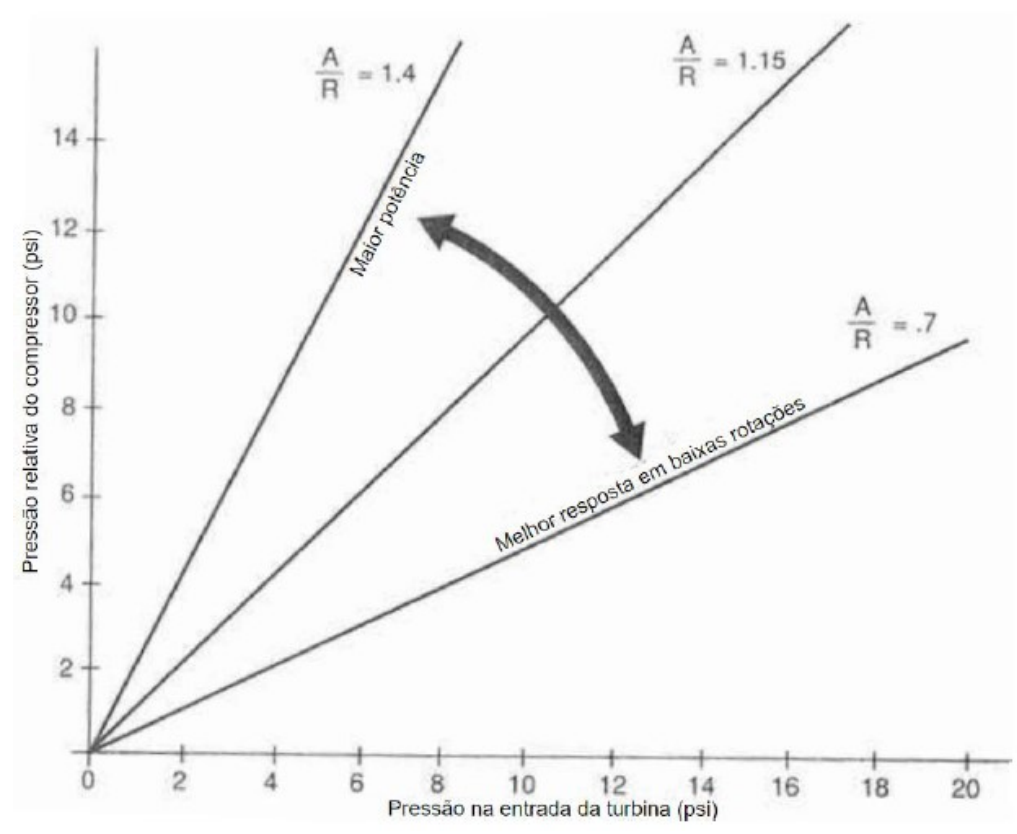

Fonte: Bell (1997). 
Figura 15 - Diâmetros máximo e mínimo dos rotores de um turbocompressor, medidos para a determinação do trim.

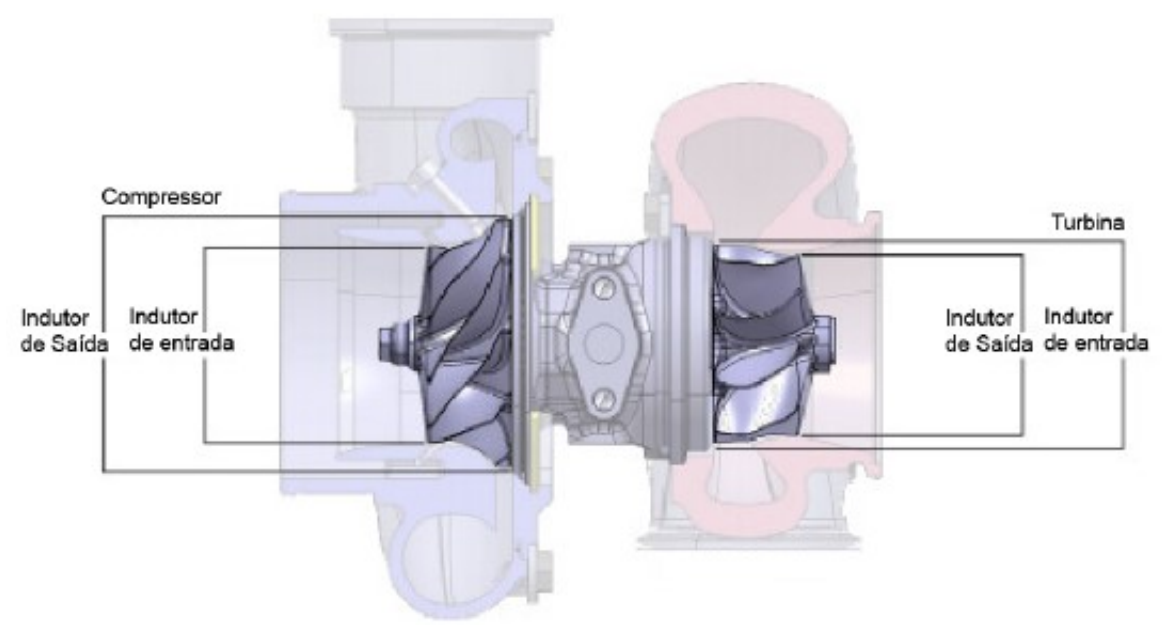

Fonte: Adaptado, Garrett.

\subsection{MAPA DE EFICÊNCIA DO COMPRESSOR}

Surge é uma condição de operação instável do sistema de compressão do fluido (ar), esse fenômeno consiste em variações periódicas do fluxo de massa no sistema de compressor e acelerador do motor, com mudanças na pressão do plenum.

O surge acentuado advém quando ocorrem fortes oscilações do sistema. Esta é uma operação prejudicial do compressor e deve ser evitada (VAN DEN BRAWMBUSSCHE, 2018). A linha de surge no mapa do compressor limita a região de operação à esquerda.

O limite de surge do compressor é caracterizado a cada RPM pela razão de pressão e vazão mássica. O surge pode ser evitado garantindo que o fluxo de massa não seja reduzido abaixo desse limite, porém, ele pode ser ultrapassado ao alterar a condição operacional de uma turbina a gás ou turbocompressor muito rapidamente (VAN DEN BRAWMBUSSCHE, 2018). 
O modelo de turbocompressor que será utilizado possui uma válvula wastegate. Esse dispositivo é capaz de desviar os gases de escape da turbina, de forma a desacelerar o rotor do compressor e impedir que rotações muito elevadas sejam atingidas. No turbocompressor utilizado, a abertura da wastegate é controlada a partir de um atuador pneumático (Figuras 16 e 17), que é acionado pela própria pressão de admissão na saída do compressor e pode ser regulado a partir da carga da mola em seu interior.

A partir da desaceleração do rotor do compressor, em uma certa faixa de operação, é possível determinar a razão de pressão máxima desejada e evitar que o compressor entre em overspeed. A região de overspeed é caracterizada no mapa do compressor pelo limite de atuação na sua parte superior. Essa região é perigosa para os componentes do turbocompressor, uma vez que rotações excessivas (superiores a $180.000 \mathrm{rpm}$ para o modelo em específico) podem causar sérios danos em seu conjunto rotativo.

Figura 16 - Diagrama de funcionamento de uma válvula wastegate.

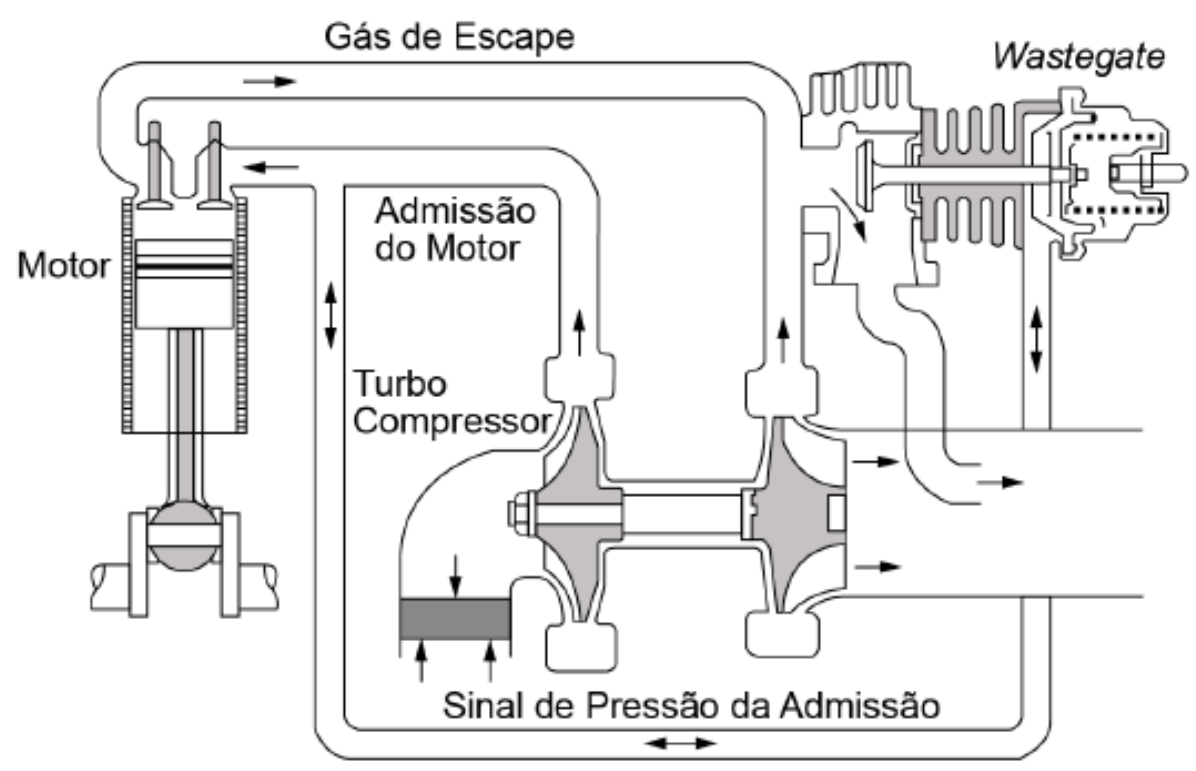

Fonte: Adaptado de <https://www.treadstoneperformance.com/blog/all-aboutinternal-wastegates-from-turbosmart>. (Acesso em 25 de Janeiro de 2020). 
Figura 17 - Diagrama de um atuador para a wastegate.

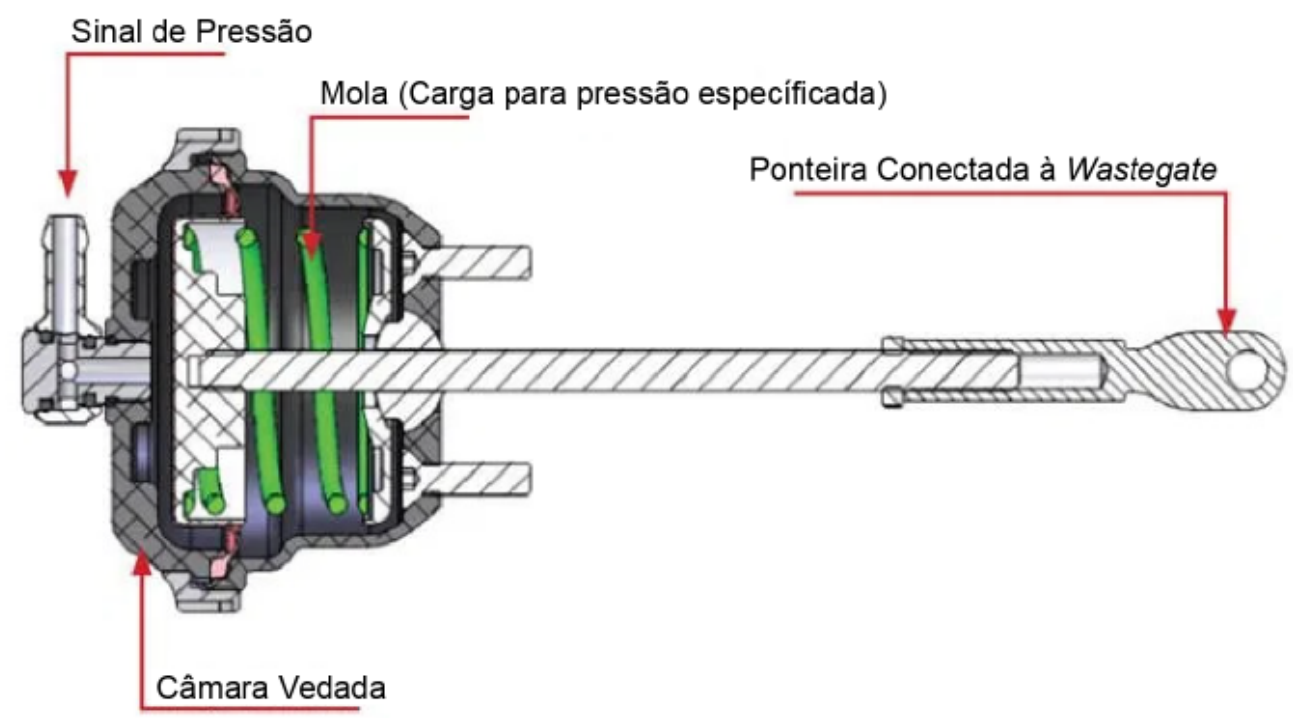

Fonte: adaptado de <https://www.treadstoneperformance.com/blog/all-aboutinternal-wastegates-from-turbosmart>. (Acesso em 25 de Janeiro de 2020).

Para auxiliar no dimensionamento do turbocompressor, será utilizado o mapa de eficiência do compressor (Figura 18). Esse mapa consiste em um gráfico circunscrito no plano cartesiano no qual o eixo horizontal representa a vazão mássica de ar (Mass Flow Axis) e o eixo vertical representa a razão de pressões (Pressure Ratio Axis). No plano, encontram-se as ilhas de eficiência (Efficiency Islands) que são responsáveis por fornecer a leitura da eficiência, indicando que, quanto menor a ilha, maior a eficiência do compressor. É importante considerar ainda, as linhas que limitam as ilhas à esquerda e à direita. Essas linhas são chamadas de Linha de Sobrecarga (Surge Line) e Linha de Estrangulamento (Choke Line), respectivamente. 
Figura 18 - Mapa de eficiência do compressor.

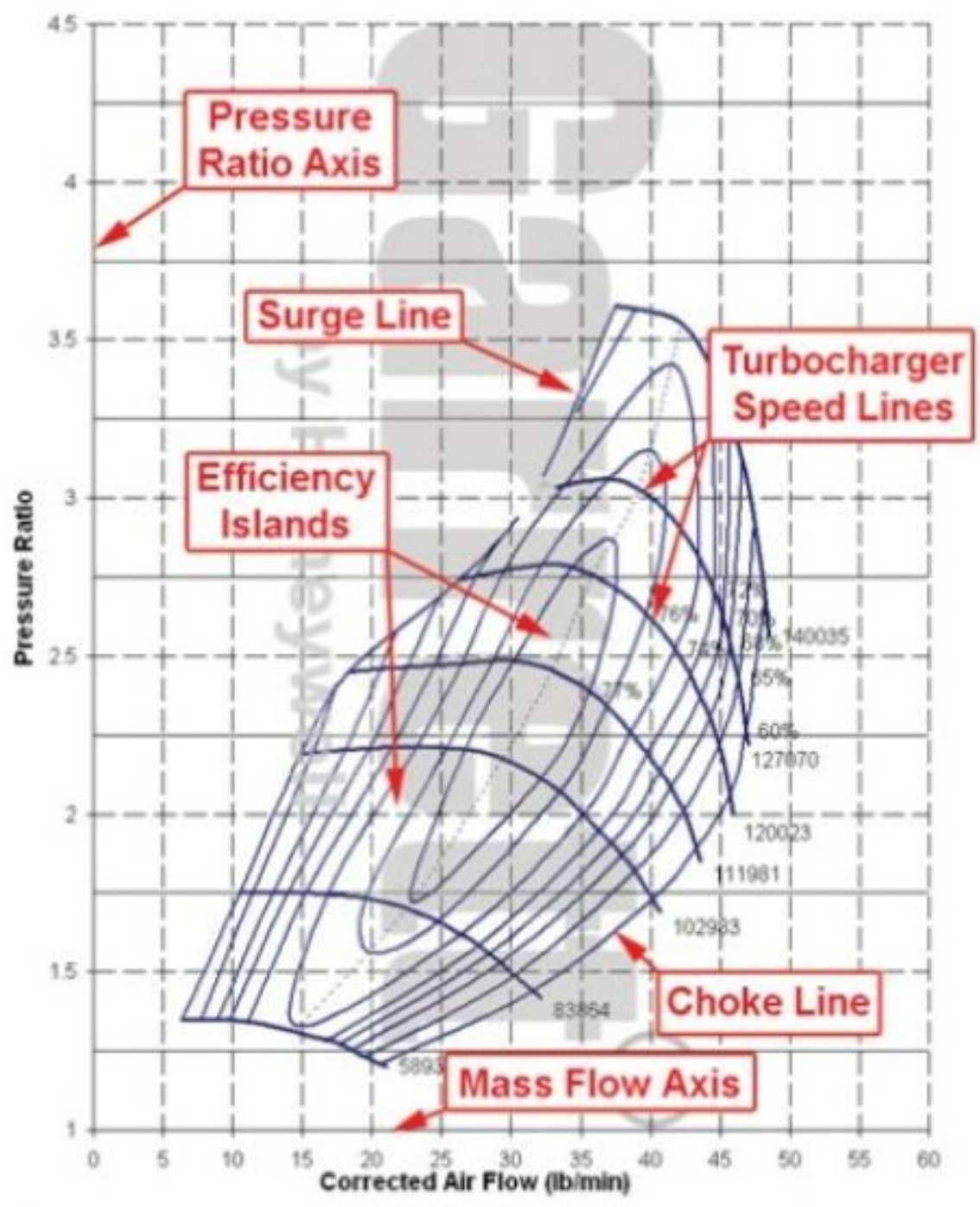

Fonte: (https://chaodaoficina.wordpress.com/2016/01/31/turbocompressoresmapas-de-eficiencial. (Acesso em 15 de Dezembro de 2019).

Se o compressor operar à esquerda da Linha de Sobrecarga, fora das ilhas de eficiência, o compressor estará funcionando de forma instável. Isso se deve à vazão mássica insuficiente que causa alta turbulência no seu interior. Esse caso pode representar um erro na escolha do turbocompressor, consistindo em um turbo maior do que o ideal para o motor. Esse efeito pode ocorrer também, quando o corpo de borboleta é fechado bruscamente em um momento no qual o motor opera 
em plena carga, porém, nesse caso a turbulência é apenas momentânea e pode ser evitada com uma válvula de descarga entre o compressor e o corpo de borboleta.

Em contrapartida, um compressor operando à direita da Linha de Estrangulamento, significa que o seu tamanho está demasiadamente pequeno para tal aplicação. Nesse caso, o compressor é incapaz de prover o fluxo de ar necessário para o funcionamento do motor. Isso pode causar grandes aumentos de temperatura responsáveis por graves problemas ao turbocompressor.

As linhas de velocidade da turbina (Turbocharger Speed Lines) não são consideradas na escolha de um turbocompressor. Entretanto, elas representam a rotação aproximada do eixo para diferentes valores de pressão de fluxo de ar e indicam sob qual faixa de rotação o turbo é mais eficiente.

\subsection{MAPA DE EFICIÊNCIA DA TURBINA}

A turbina utilizada por um turbocompressor converte parte da energia contida nos gases de escape do motor em energia mecânica para acionar o compressor. No geral, as turbinas podem ser do tipo axial ou radial.

A turbina do tipo axial permite a passagem do fluxo de gases de escape apenas na direção axial. Esse tipo de turbina, no entanto, é muito pouco utilizado devido a sua maior complexidade, e na maioria das vezes seu maior tamanho e peso.

As turbinas de fluxo radial, por outro lado, são muito mais comuns em aplicações automotivas e utilizam uma tecnologia mais tradicional. Esse tipo de turbina recebe a vazão de gás radialmente, de fora para dentro. Seu tamanho e peso são reduzidos quando comparados à turbina de fluxo radial $e$, por isso, é a mais utilizada.

Existe uma grande dificuldade no dimensionamento de turbinas, pois alguns fabricantes não disponibilizam o mapa de eficiência. As variáveis necessárias para escolha de uma turbina podem ser estimadas previamente à instalação do turbocompressor. Os mapas de eficiência de turbinas contam com informações referentes à energia necessária na turbina para que o compressor comece a gerar pressão. Dessa forma, é possível saber qual a mínima rotação necessária do motor, 
para que a turbina seja capaz de fornecer energia suficiente ao compressor, para que este comece a comprimir ar para o interior dos cilindros.

\subsection{INTERCOOLER}

O intercooler é um trocador de calor compacto de fluxo cruzado em que os fluidos não são misturados. Existem dois tipos de intercooler:

- ar-ar

- ar-água

A função do intercooler é basicamente resfriar o ar que é aquecido durante o processo no compressor, o que diminui sua densidade e quanto mais denso o ar melhor é para o motor, tornando possível injetar mais combustível na mistura e assim obter maior potência.

Um intercooler bem dimensionado deve ser capaz de resfriar eficientemente o ar e ao mesmo tempo causar uma baixa perda de carga.

Para isso de suma importância que ele seja instalado em local adequado, onde haja corrente de ar abundante para que a troca de calor seja eficiente. Nas Figuras $(19,20,21$ e 22 ) é possível verificar o intercooler fabricado para o motor em algumas etapas:

Figura 19 - Intercooler instalado no motor.

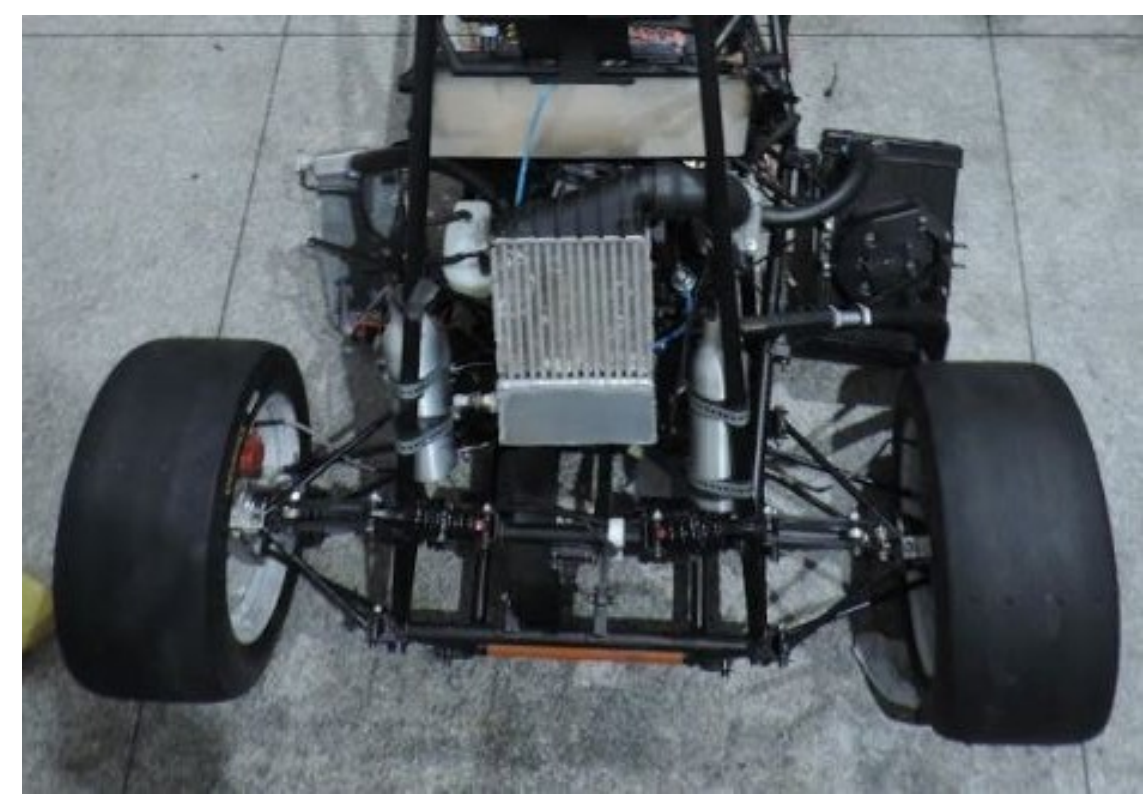

Fonte: Elaboração própria. 
Figura 20 - Detalhe do intercooler: Plenum.

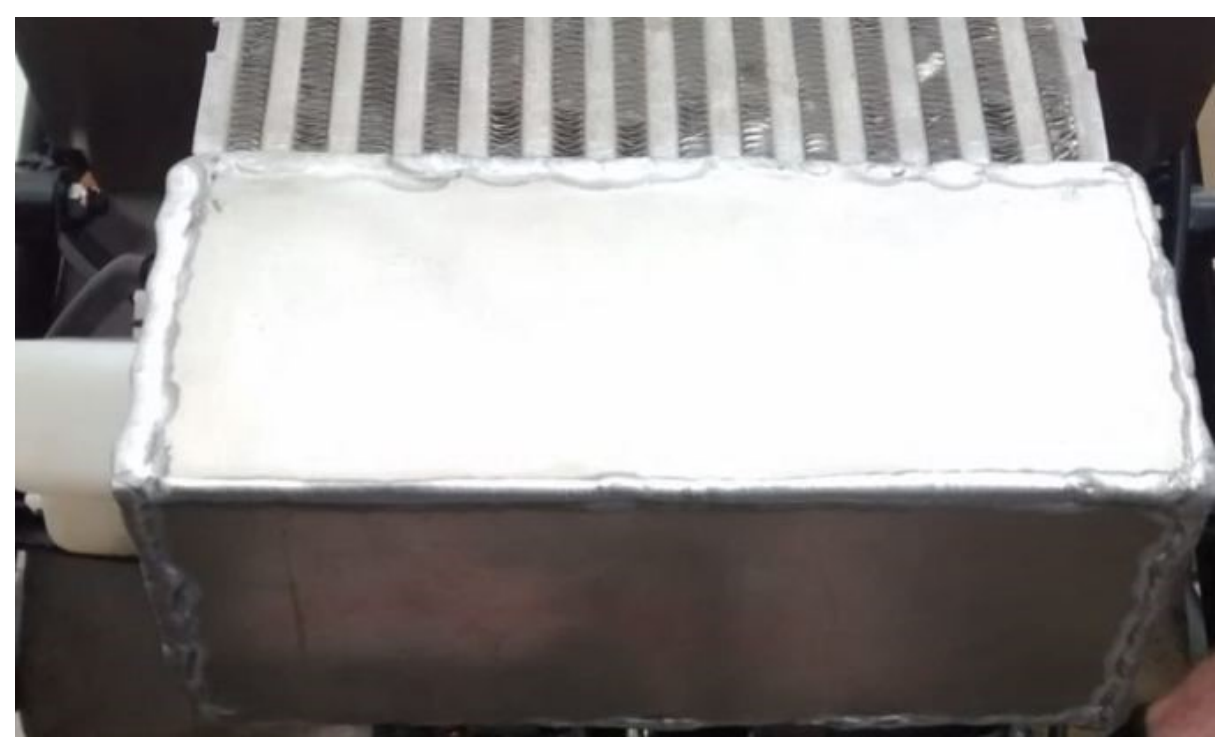

Fonte: Elaboração própria.

Figura 21 - Detalhes do Intercooler.

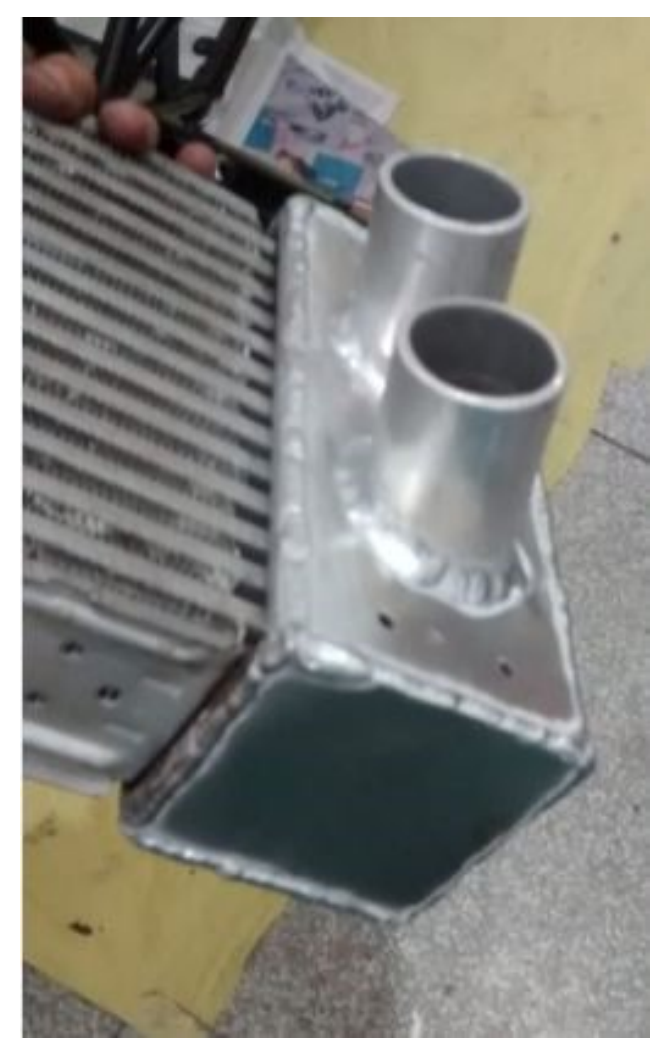

Fonte: Elaboração própria. 
Figura 22 - Integração entre intercooler e corpo de borboleta.

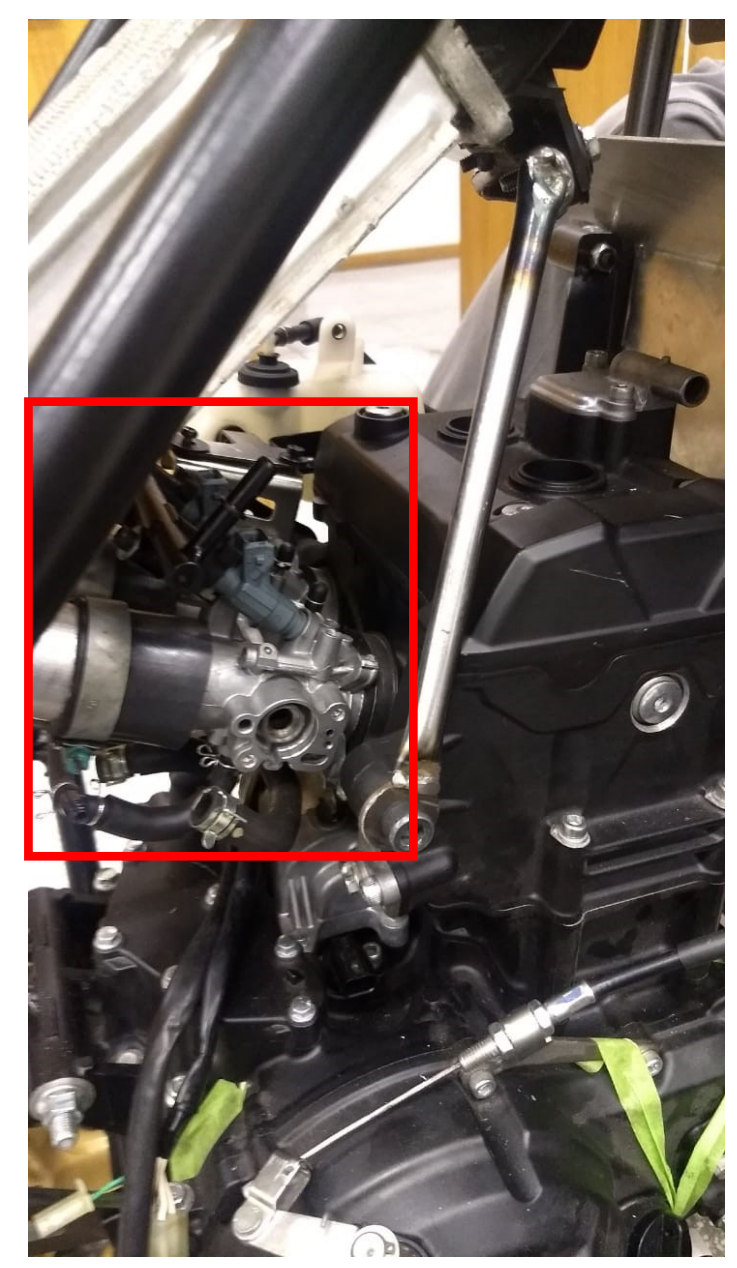

Fonte: Elaboração própria.

\subsection{ETANOL}

O etanol é um combustível produzido a partir de fontes renováveis, principalmente da cana-de-açúcar e do milho.

O etanol é amplamente utilizado nos veículos leves seja como combustível puro ou como aditivo antidetonante para gasolina (BORETTI, 2010). 
Sarathy et al. (2014) mencionam que o etanol tem sido utilizado desde os primeiros anos de produção de automóveis, especialmente no Brasil, onde o etanol tem uma história antiga desde 1980 como combustível automotivo.

Atualmente, não são produzidos motores dedicados exclusivamente para funcionar com etanol no país. Os motores denominados flex, fornecem ao consumidor a possibilidade da utilização da gasolina brasileira ( $27 \%$ de etanol anidro) ou do etanol hidratado.

A utilização de biocombustíveis de alta octanagem como o etanol, tem-se mostrado uma poderosa ferramenta para atingir os níveis de consumo e emissões de poluentes estipulados pelos órgãos reguladores. As propriedades do etanol como combustível permitem o funcionamento do motor em condições de altas pressões na câmara de combustão com um menor risco de detonação (do inglês, Knock) (BORETTI, 2012).

A alta octanagem aliada ao alto calor latente de vaporização do etanol, pode ser utilizada como benefício em motores de injeção direta, tornando possível o desenvolvimento de motores com maiores razões de compressão, o que por sua vez resulta em motores mais eficientes termicamente, (BORETTI, 2012).

Em motores sobrealimentados, a utilização de biocombustíveis de alta octanagem possibilita maiores pressões de sobrealimentação e maiores valores de avanço de ignição sem a tendência a detonação, esses efeitos contribuem para maiores eficiências do motor, (Boretti, 2012).

No Brasil utiliza-se o etanol hidratado ou álcool etílico hidratado, composto por de $94 \%$ de etanol e $6 \%$ de água, na base volumétrica (ANP, 2020).

A octanagem, ou número de octano, é a grandeza que representa a resistência da mistura do combustível com ar à autoignição, responsável pela detonação (BRUNETTI, 2012).

A resistência à autoignição dos hidrocarbonetos individuais varia muito, dependendo do seu trabalho e estrutura, e das condições operacionais do motor. Em geral, na pressão atmosférica, para álcoois, compostos aromáticos e hidrocarbonetos leves fica na faixa entre 500 e $600^{\circ} \mathrm{C}$. Para compostos parafínicos e olefínicos não ramificados de cadeia longa, o valor cai bastante, sendo da ordem de 200 a $250{ }^{\circ} \mathrm{C}$ (BRUNETTI, 2012).

Existem dois métodos para calcular a octanagem do combustível: 
- Método Motor (MON - Motor Octane Number) - Regulamentado pela Norma ASTM D 2699, este método avalia a resistência do combustível à detonação em condições severas de operação do motor, que é em plena carga ou alta rotação.

- Método Pesquisa (RON - Research Octane Number) - Regulamentado pela Norma ASTM D 2700, este método avalia a resistência do combustível à detonação em condições menos severas de operação do motor, que é em baixa carga ou baixa rotação.

Como no RON as condições são menos severas, o RON indicará sempre um valor maior do que o MON. Porém, não existe o certo ou errado nos dois métodos, o que ocorre é que dependendo do projeto do motor e as condições em que ele opera, a resistência à detonação do combustível poderá ser melhor representada pelo valor RON ou MON.

No Brasil é adotado o índice antidetonante IAD, que é uma média aritmética obtida entre os dois métodos (RON e MON). O valor do IAD para alguns combustíveis comercializados no Brasil pode ser visto na Tabela 1.

$$
I A D=\frac{M O N+R O N}{2}
$$

Tabela 1 - Octanagem de combustíveis no Brasil.

\begin{tabular}{|l|l|l|l|l|}
\hline & $\begin{array}{l}\text { Gasolina } \\
\text { Comum }\end{array}$ & $\begin{array}{l}\text { Gasolina } \\
\text { Premium }\end{array}$ & $\begin{array}{l}\text { Gasolina } \\
\text { Podium }\end{array}$ & $\begin{array}{l}\text { Etanol } \\
\text { Hidratado }\end{array}$ \\
\hline $\begin{array}{l}\text { Octanagem } \\
\text { (IAD) }\end{array}$ & 87 & 91 & 95 & 105 \\
\hline
\end{tabular}

Fonte: BRUNETTI (2012).

O álcool etílico possui uma quantidade energética inferior à da gasolina, porém, por conter em sua composição química o oxigênio, necessita de uma menor quantidade de ar para a combustão completa. A mistura ar/combustível do álcool etílico possui uma maior quantidade de energia disponível para uma mesma massa de $\operatorname{ar}$ (BAETA, 2006).

Segundo Pulkrabek (1997) as vantagens do etanol como combustível são: 
1- Pode ser obtido de inúmeras fontes, tanto naturais quanto manufaturadas;

2 - Contém alta octanagem com alta resistência à detonação. Uma maior resistência à detonação possibilita a utilização de razões de compressão maiores, resultando em um motor mais eficiente;

3 - Apresenta menores índices de emissões de poluentes quando comparado com a gasolina;

4 - Alto calor latente de vaporização, o que resulta num resfriamento durante os processos de admissão e compressão, aumentando a eficiência volumétrica do motor;

5 - Baixo teor de enxofre no combustível.

Pode-se citar as desvantagens do etanol (PULKERABEK, 1997):

1 - Baixo conteúdo energético. Isso significa que quase duas vezes mais etanol é necessário em relação à gasolina para fornecer a mesma quantidade energética ao motor;

2 - Maior quantidade de aldeídos nos gases de escape, o que para emissões seria mais um problema;

3 - Etanol é mais corrosivo do que a gasolina ao cobre, bronze, alumínio, borracha e plástico, impondo algumas restrições aos projetos de motores que utilizam o etanol como combustível;

4 - Dificuldade de partida nos motores em temperaturas muito baixas, devido à baixa pressão de vapor e elevado calor de vaporização. No Brasil, existem dois tipos de tecnologias utilizadas para a partida a frio, a tecnologia mais antiga injeta-se uma pequena quantidade de gasolina durante a partida para iniciar o funcionamento do motor, outra tecnologia mais avançada utiliza um sistema para o aquecimento do combustível antes de iniciar a partida.

\subsection{MISTURA AR/COMBUSTÍVEL}

Em motores de combustão interna mais atuais, a alimentação de combustível é feita por um sistema de injeção eletrônica. Esse sistema fornece a quantidade de combustível adequada para a formação da mistura ar/combustível, para que possa ser eficientemente queimada, melhorando o torque, consumo de 
combustível, níveis de emissões de poluentes, para toda faixa de rotação do motor (RODRIGUES FILHO, 2014).

Devido à composição dos produtos de combustão serem significativamente diferentes para misturas pobres e ricas, e devido à razão ar/combustível estequiométrica depender da composição do combustível, a razão das relações ar/combustível real, $(A / F)_{\text {real }}$, e estequiométrica, $(A / F)_{e s t}$, torna-se um parâmetro mais informativo para a definição da composição da mistura, (Heywood, 1988). O fator que expressa essa relação entre razões de ar/combustível é chamado de fator lambda, $\lambda$, e pode ser calculado pela Equação (2.2):

$$
\lambda=\frac{(A / F)_{\text {real }}}{(A / F)_{\text {est }}}
$$

A partir do fator lambda, da razão ar/combustível estequiométrica da mistura e da vazão mássica de ar admitida no cilindro, $\dot{m}_{a r}$, é possível determinar a vazão mássica de combustível, $\dot{m}_{c o m b}$, a ser fornecida para o motor, sendo obtida através da Equação (2.3):

$$
m_{c o m b}=\frac{m_{a r}}{\lambda .(\mathrm{A} / \mathrm{F})_{\mathrm{est}}}
$$

O fator lambda indica a condição de operação do motor, de forma qualitativa, no que se refere a composição da mistura formada. Fator lambda unitário, $\lambda=1$, indica que a mistura é estequiométrica, para mistura rica o fator lambda indica valores menores do que uma unidade, $\lambda<1$, e para mistura pobre o fator lambada indica valores maiores que uma unidade, $\lambda>1$.

A Figura (23) mostra a influência do fator lambda nos parâmetros de desempenho (a), e nos níveis de emissões (b) de um motor de combustão interna de ignição por centelha. 
Figura 23 - Influência do fator lambda nos parâmetros de desempenho (a) e nos níveis de emissões (b).

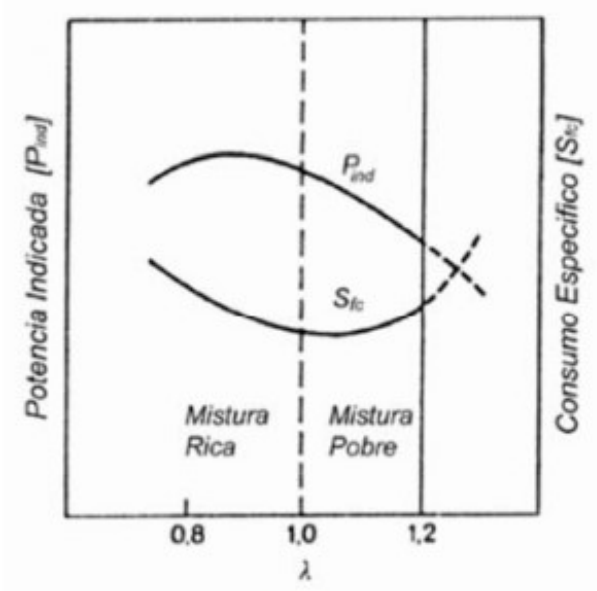

(a)

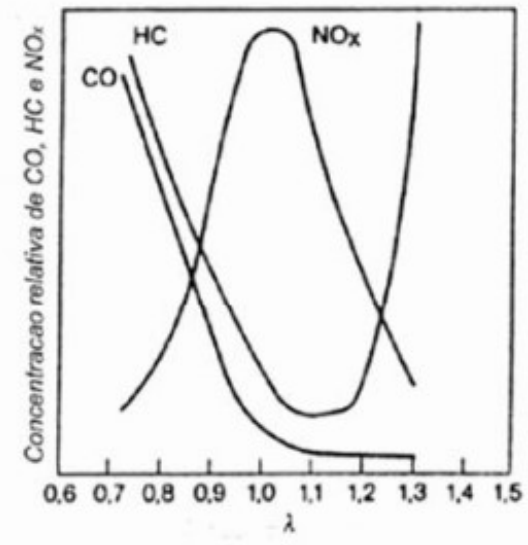

(b)

Fonte: Rodrigues Filho (2014).

\subsection{AVANÇO DE IGNIÇÃO}

O ponto de avanço de ignição é o momento em que ocorre a centelha para o início da combustão em motores ciclo Otto. Quando se mantém constantes as quantidades de ar e combustível, pode-se obter a otimização da curva de pressão no cilindro através da variação do ponto de avanço de ignição do motor em relação ao ângulo do virabrequim.

Conforme a rotação do motor aumenta, deve-se corrigir o ponto de avanço de ignição para um melhor desempenho do motor. A Figura 24 representa o comportamento do avanço de ignição de acordo com a rotação do motor. 
Figura 24 - Variação do ponto de avanço de ignição de acordo com a rotação do motor.

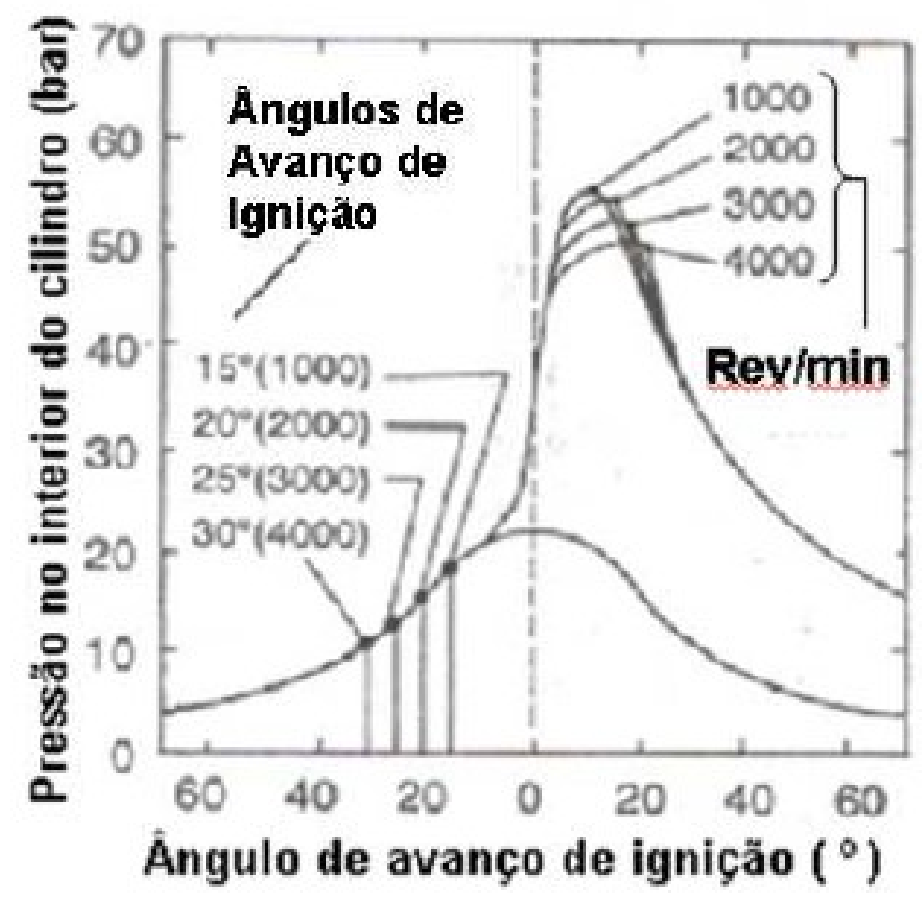

Fonte: Adaptado Heisler (2005).

A Figura 25 mostra o resultado do aumento da rotação do motor sem que ocorram as correções nos ângulos de avanço de ignição. Pode-se observar uma queda de pressão no interior da câmara de combustão do motor. 
Figura 25 - Comportamento da pressão do motor de acordo com o ângulo de avanço de ignição.

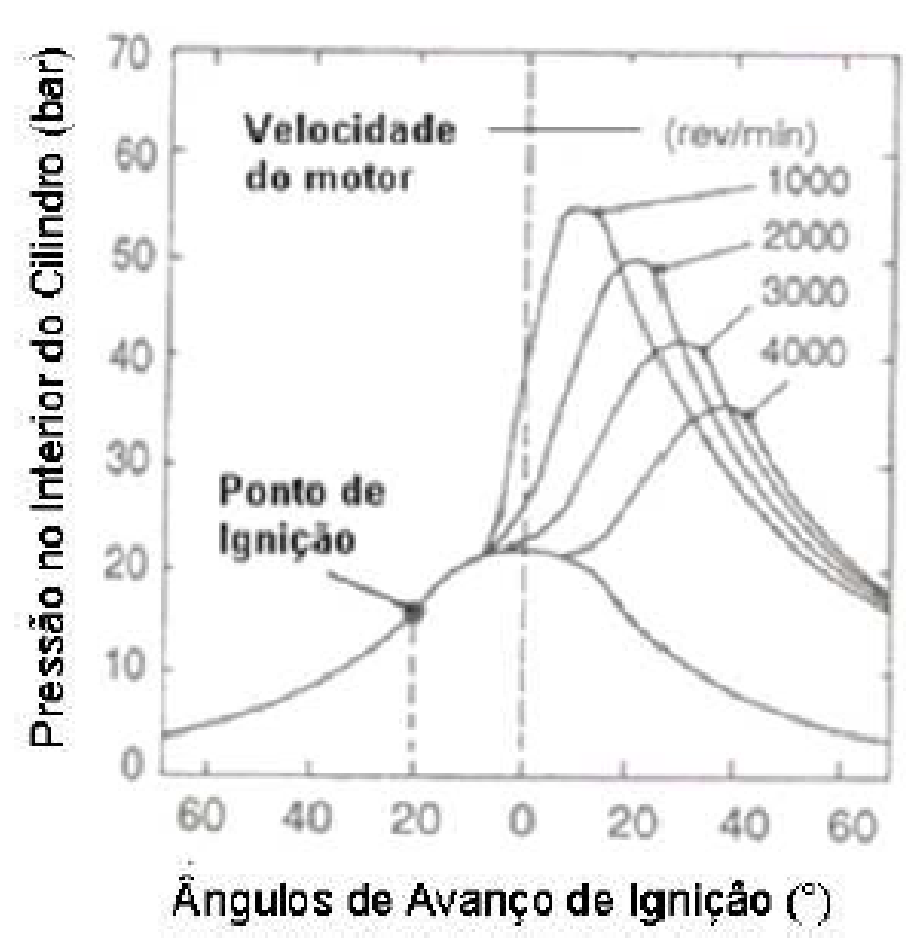

Fonte: Adaptado Heisler (2005).

Heywood (1988) explica o comportamento da pressão na câmara de combustão de acordo com o ângulo de avanço de ignição. Antecipando-se o ponto de ignição em relação ao Ponto Morto Superior (PMS), obtém-se a antecipação do início da combustão.

Duarte (1996) realizou uma simulação do efeito dos parâmetros operacionais no desempenho de um Motor de Combustão Interna. A otimização da pressão média efetiva nos cilindros é obtida variando o ângulo de avanço de ignição até um ponto ótimo de torque do motor, onde a máxima pressão média efetiva é alcançada. A partir desse ponto pode ocorrer detonação na câmara de combustão. A detonação é um fator prejudicial ao rendimento e componentes do motor.

Stone e Ball (1999) relata que com o adiantamento excessivo do ponto de avanço de ignição, o trabalho de compressão aumenta enquanto diminui o trabalho de expansão, resultando na diminuição do rendimento do motor. 
Segundo Martins (2006), a determinação do ponto ótimo de torque do motor é relativamente difícil de ser encontrada, pois o comportamento da curva de pressão torna-se semelhante com os pontos de avanço nessa intermediação. Dessa forma, algumas regras práticas são aplicadas: a pressão máxima deverá ocorrer cerca de $16^{\circ}$ depois do Ponto Morto Superior, metade da mistura deve estar queimada $8^{\circ}$ depois do Ponto Morto Superior.

Nos motores de ignição por centelha, o avanço de ignição deve ser estabelecido de acordo com a rotação e carga do motor. Motores do tipo flex, que trabalham com mais de um tipo de combustível, usam mapas de avanço de ignição diferenciados para cada tipo de combustível e de acordo com diferentes proporções de misturas.

Segundo Galloni (2009), somente alguns poucos ciclos do motor queimam com um ponto ótimo de avanço de ignição, resultando em uma perda de potência e eficiência do motor nos pontos fora do ponto ótimo.

A possibilidade de trabalhar com as variações nos pontos de avanço de ignição no motor, permitem que outras variáveis possam ser controladas em certos níveis, como a temperatura de chama na câmara de combustão, temperatura dos gases de escape e formação de emissões de gases nocivos ao meio ambiente. Logo, o mapeamento do avanço de ignição é um recurso de extrema importância na calibração do motor.

\subsection{CABEÇOTE}

Geralmente é utilizada uma liga de alumínio fundido para a fabricação do fundido bruto do cabeçote devido a sua boa condutividade térmica e adequada propriedades mecânicas (CARVALHO, 2009).

$\mathrm{Na}$ superfície inferior do cabeçote são encontradas cavidades na direção dos cilindros que formam com a parte superior dos pistões as câmaras de combustão. $O$ cabeçote também é composto por galerias de circulação de fluido de arrefecimento e óleo de lubrificação, também galerias para as velas de ignição e os bicos injetores de combustível. Existem aberturas que são chamadas de janelas de admissão e exaustão (CARVALHO, 2009). 
Através das janelas de admissão, têm-se a mistura ar-combustível para motores de ignição por faísca, ou simplesmente ar para motores Diesel, que são admitidos para o cilindro. A mistura queimada é expulsa do cilindro através da janela de exaustão. No cabeçote também são encontrados furos destinados a guiar o movimento das válvulas de admissão e exaustão (guias de válvulas). As superfícies das janelas de admissão e exaustão são usinadas para que as válvulas sejam assentadas, assim, garantindo que a passagem de mistura seja vedada quando as válvulas estão fechadas, uma junta de cabeçote é colocada entre o cabeçote e o bloco do motor para vedação (CARVALHO, 2009).

\subsection{COMANDO DE VÁLVULAS}

O comando de válvulas é um dos componentes mais importantes do motor, ele executa a tarefa de controlar a entrada da mistura ar-combustível e a saída dos gases resultantes da combustão. O comando de válvulas é composto por um cilindro onde são usinados os cames que atuam na abertura e fechamento das válvulas, sua geometria pode ser vista na Figura 26, (BERNARDI, 2015).

Figura 26 - Comando de Válvulas Yamaha R3.

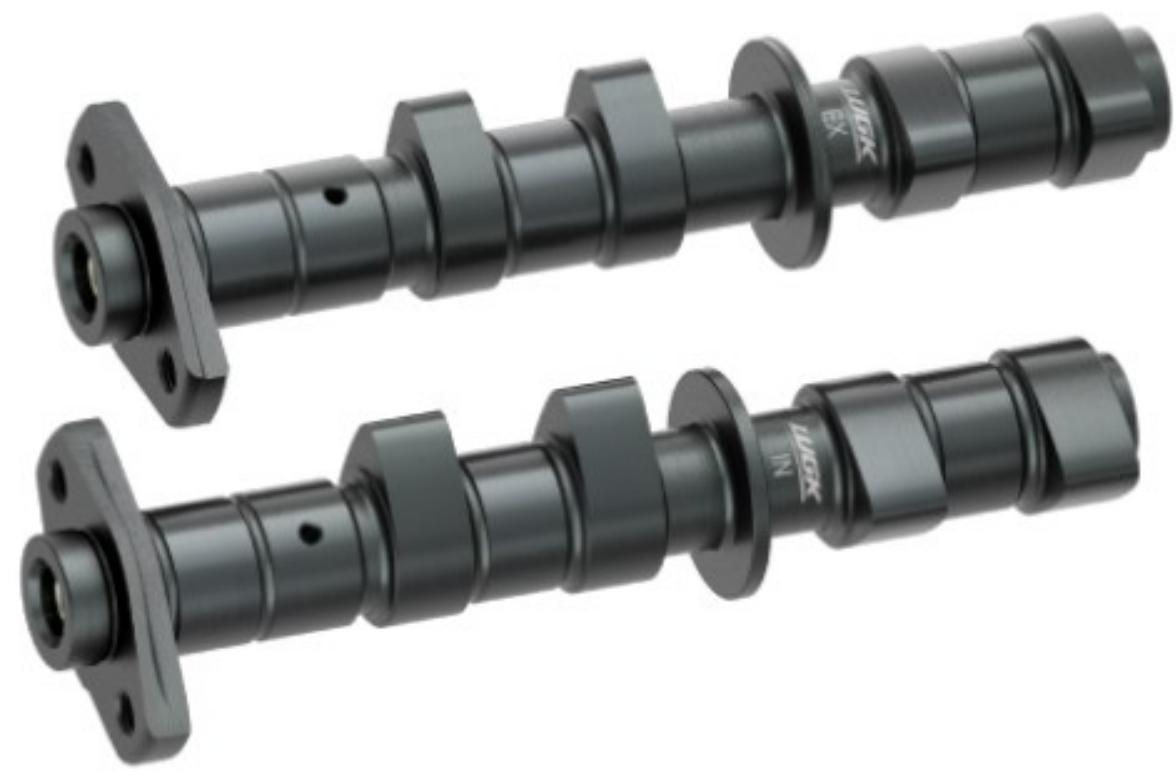

Fonte: WGK (2021). 
De acordo com Ihlemann (2003), existem diversos tipos e construções de comandos de válvulas, porém todos têm em comum a função de realizar a abertura e fechamento das válvulas. O que diferencia é a quantidade de válvulas abertas por cilindro e seu local de funcionamento, seja no bloco do motor ou no cabeçote. A seguir tem-se a descrição dos dois tipos de construção:

Overhead Valves (OHV) é um mecanismo de acionamento que depende da disposição das válvulas, geralmente são utilizadas válvulas suspensas, acionadas por balancins articulados ou um balancim articulado e uma haste impulsora denominada de vareta. Os elementos de acionamento citados servem para transformar a curva de elevação determinada pelo perfil do came em um movimento de curso da válvula de troca de gases.

Overhead Camshaft (OHC) é quando os eixos de comando de válvulas são instalados no cabeçote, acima da linha de separação do cabeçote com o bloco (Figuras 27 e 28).

Figura 27 - Comando de válvulas situado no bloco.

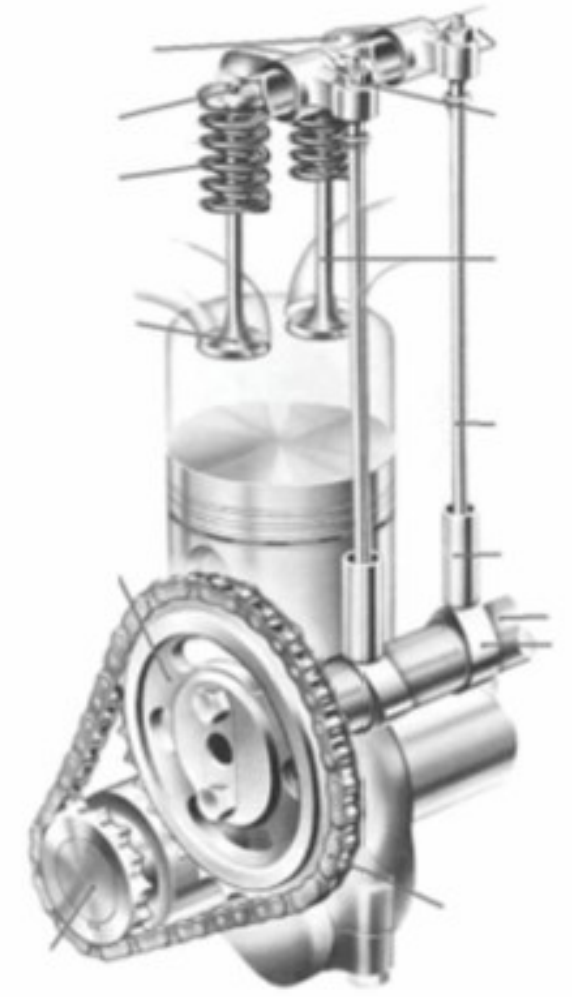

Fonte: Adapatado de Tomoyose (2013). 
Figura 28 - Comando de válvulas e virabrequim.

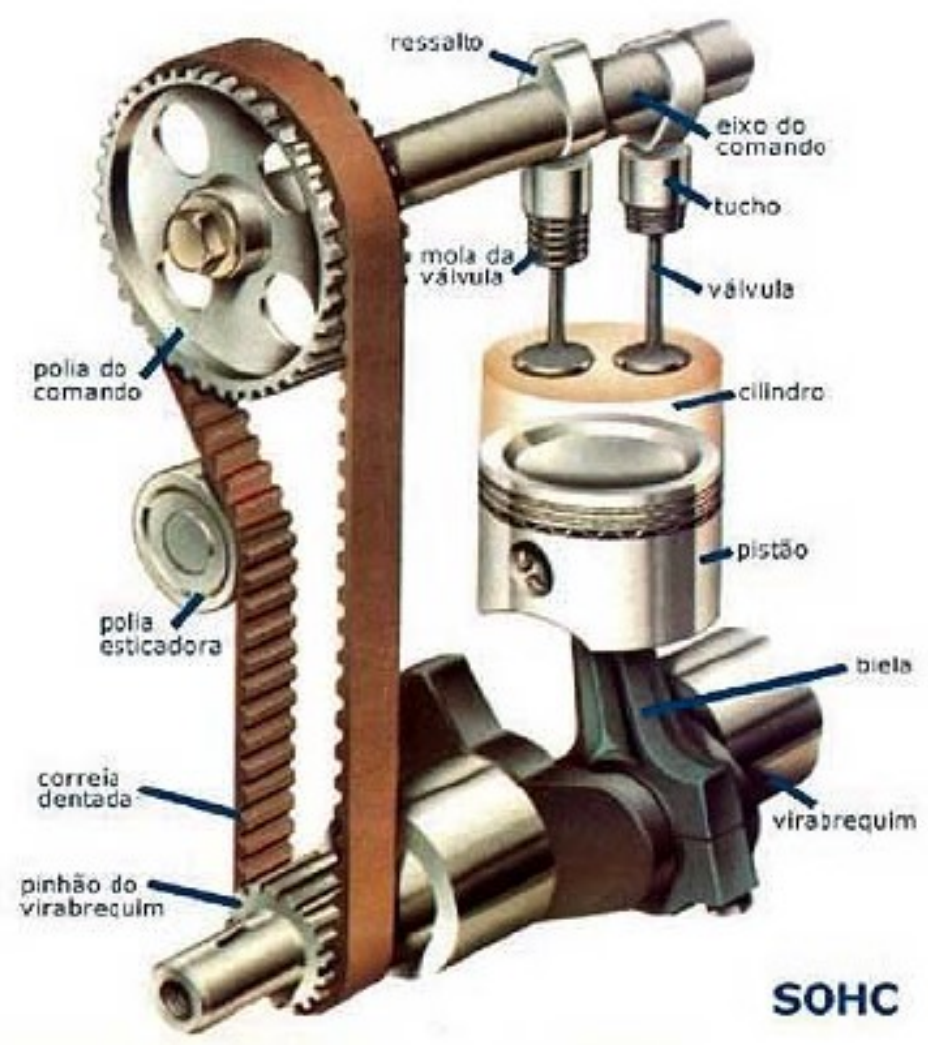

Fonte: GOODYEAR (2005).

Alterando as configurações do comando de válvulas pode-se mudar consideravelmente os parâmetros de funcionamento do motor, fazendo com que o torque seja maior ou menor em determinada faixa de rotação, melhorando o desempenho conforme o uso do veículo (ROMMER , 2011).

A operação do comando de válvulas é sincronizada com o virabrequim do motor, essa ligação pode ser feita através de engrenagens, correias dentadas ou correntes. Nos motores quatro tempos o ciclo completo é realizado com duas voltas no virabrequim $\left(720^{\circ}\right)$ e uma volta do comando de válvulas $\left(360^{\circ}\right)$.

As diversas dimensões do came de válvulas desempenham função específica, alterando cada uma delas terá um desempenho diferente no motor. As nomenclaturas que cada geometria recebe podem ser vistas na Figura 29. 
Figura 29 - Geometria do ressalto do comando de válvulas.

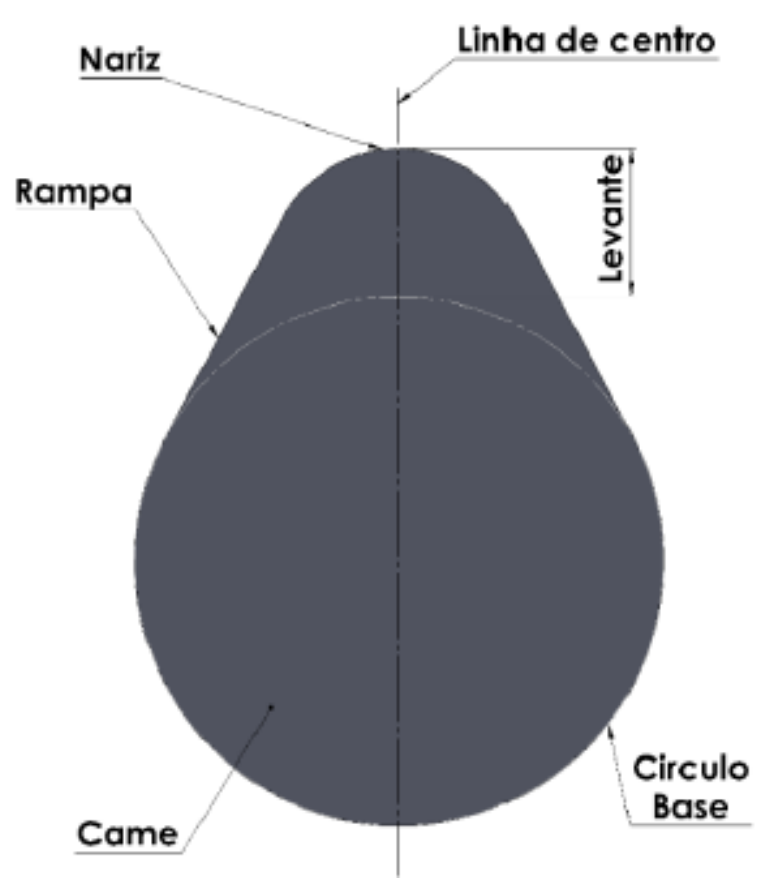

Fonte: Adaptado de Lima (2018).

Cada uma das partes do ressalto possui uma função específica.

a) Círculo base é o local da geometria do comando de válvulas onde as válvulas, tanto de admissão quanto de exaustão, estarão fechadas, ou seja, o motor estará na fase de compressão ou expansão.

b) Came é o ressalto do comando de válvulas, a sua geometria define quando e por quanto tempo as válvulas deverão permanecer abertas.

c) Rampa é uma das linhas de construção do came, ela define com qual velocidade e aceleração acontecerá a abertura das válvulas. O desenho das rampas podem ser simétrico ou assimétrico. Nos comandos com rampas simétricas tanto a abertura como o fechamento de válvulas são iguais, já no desenho assimétrico a rampa de abertura poderá ter uma inclinação diferente da rampa de fechamento. Essa escolha vai depender dos resultados obtidos para o projeto do motor. 
d) Levante ou lift é o máximo que o comando irá abrir a válvula, ele é medido obtendo a medida da base até o nariz subtraindo com o diâmetro do círculo base.

e) Nariz é o local onde se alcança o levante máximo, ou seja, a abertura máxima da válvula. É durante a passagem pelo nariz que acontece o fim da abertura e início do fechamento da válvula.

As fases do comando de válvulas podem ser vistas na Figura 30.

Figura 30 - Fases de um comando de válvulas.

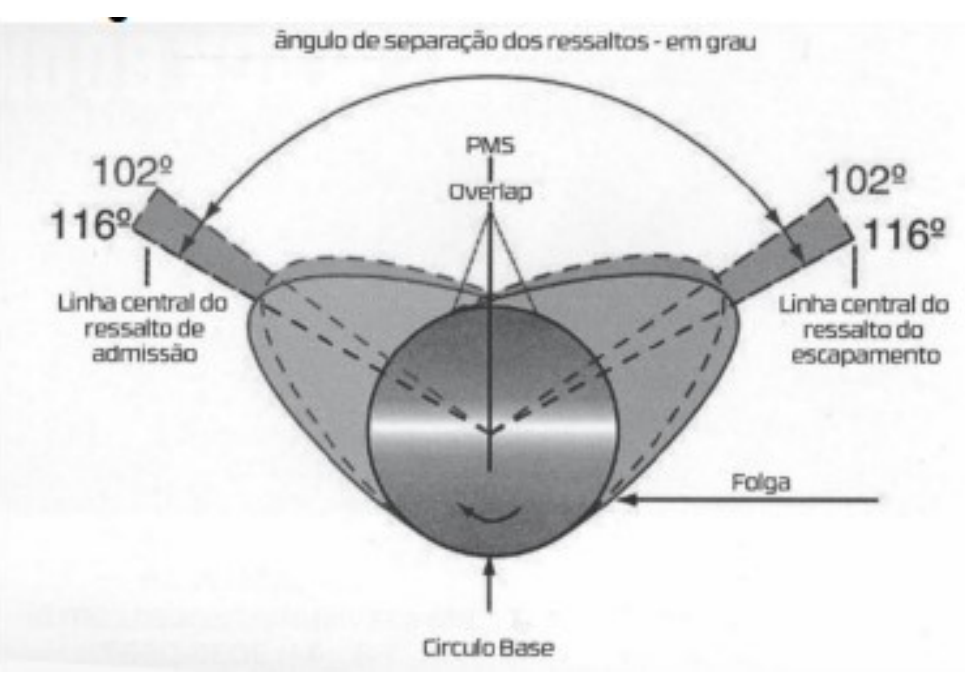

Fonte: Lima, 2018.

f ) Permanência ou duração - é o ângulo entre o início da abertura até o final do fechamento da válvula. Este valor é dado em relação ao ângulo do virabrequim do motor, no qual é instalado um disco graduado e um relógio comparador no topo da válvula para verificar o exato momento em que a válvula começa a abertura e posteriormente termina o fechamento. Segundo Lima (2018) para início na medição coloca-se o motor no PMS e gira-se o motor até o relógio comparador mostrar a abertura de 0,05 polegadas ou $1,27 \mathrm{~mm}$ e continua-se girante até a válvula abrir e começar a fechar chegando novamente a essa medida, sabendo o valor em 
graus que a válvula abriu e também o valor em que fechou tem-se a duração ou permanência deste ressalto. $O$ processo de admissão começando mais cedo antes do PMS favorece o ganho de potência e torque em baixas rotações, já o processo de admissão acontecendo mais próximo do PMS favorece o ganho de torque e potência em rotações altas.

g) Separação entre os cames ou lobe separation - é a relação entre o centro dos picos dos ressaltos de admissão e de escapamento. Essa separação influencia o vácuo do motor e também sobre o período em que tanto a válvula de admissão como de escape ficaram abertas ao mesmo tempo. De acordo com Lima (2018), quanto maior a separação entre os ressaltos menor será e overlap e com isso eleva-se a pressão dentro dos cilindros, move-se a faixa de torque para rotações mais baixas, aumenta-se o torque máximo e eleva-se o vácuo do motor. Quanto menor a separação dos ressaltos, se reduz a pressão nos cilindros, maior o overlap e move-se a faixa de torque para rotações mais altas e reduz a possibilidade de auto-ignição.

h) Cruzamento de válvulas ou overlap - é a definição de qual ângulo as válvulas de admissão e escape estarão abertas ao mesmo tempo. Esse fenômeno acontece durante a finalização do ciclo de duração do escapamento e início da duração da admissão. Quanto menor o tempo de overlap maior será a pressão nos cilindros em baixas rotações. Um maior tempo de overlap deixa a marcha lenta irregular, melhorando o rendimento em rotações mais altas.

Segundo Martins (2006), aproveita-se os efeitos dinâmicos de inércia e de ressonância da entrada e saída do cilindro para melhorar o enchimento e o esvaziamento deste. Assim, o tempo de abertura será maior, começando antes do PMS e terminando depois do PMI no caso da admissão, e iniciando antes do PMI e terminando após o PMS no caso da exaustão. 
Na admissão da mistura a válvula de admissão está aberta durante todo o percurso do pistão do PMS até o PMI e permanece aberta mais um tempo além do PMS, isso faz com que a inercia da mistura continue atuando e mais quantidade de mistura seja admitida, fazendo com que a pressão no interior do cilindro seja elevada e uma maior massa de ar se concentre dentro do cilindro em comparação com a quantidade de massa de ar que caberia dentro do cilindro em pressão atmosférica. A abertura da válvula de admissão também acontece antes do pistão chegar ao PMS, isso se dá para que a inércia dos gases de escape que ainda estão saindo pela válvula de escape provoque a aspiração de ar da admissão, lavando o cilindro dos gases de escape e evitando, desta forma, com que os gases de escape saiam pela admissão.

No escape a válvula abre antes do pistão chegar ao PMI, sendo que esta abertura antecipada faz com que os gases queimados saiam o quanto antes do cilindro devido à pressão elevada, fazendo com que o pistão encontre menor resistência quando estiver subindo e realizando a exaustão. Como dito anteriormente, a válvula de escape continua aberta após o PMS para fazer a lavagem do cilindro.

Seguindo esta mesma linha de raciocínio Brunetti (2012) fala sobre dois fenômenos que atuam no período de exaustão e que atuam no fluxo dos gases. Um deles acontece em virtude do pulso de pressão positiva dos gases liberados pela válvula de escape e que percorre os dutos de escapamento. Esse pulso ao encontrar um ponto onde exista uma descontinuação, restrição ou um ponto com súbita expansão de área será refletido de volta e com sinal negativo formando uma onda de depressão que ao encontrar a válvula de escape e de admissão abertos na fase de overlap ajudará na admissão da mistura fresca e, também na eliminação dos resíduos da queima. O outro fenômeno que Brunetti (2012) cita é chamado de efeito Kadenacy, que acontece com a abertura da válvula de escape, os gases ao saírem pelo duto de escape, ainda em grande pressão, encontram uma coluna de gás que estava contida no duto e a expulsa com grande velocidade pelo escapamento, ao sair pelo extremo do duto cria uma onda de expansão que diminui a pressão dentro do duto de escapamento e, desta forma, também, auxilia a admissão da mistura fresca. 
Para cumprir sua função, a válvula de admissão deve abrir e a válvula de escape fechar perto do PMS. Para facilitar o escoamento dos gases de exaustão para fora do cilindro, a abertura da válvula de exaustão é antecipada e ocorre antes que o pistão chegue ao PMI, assim como seu fechamento é atrasado até um ponto em que o pistão já reverteu o sentido de seu movimento, deslocando-se em direção ao PMI, como pode ser visto no diagrama da Figura 31. De maneira similar, para permitir um melhor preenchimento do cilindro com a mistura ar-combustível a válvula de admissão abre antes de o pistão atingir o PMS no tempo de exaustão. A válvula de admissão permanece aberta durante todo o curso de admissão fechando perto do início do ciclo de compressão.

Figura 31 - Diagrama de tempos de válvulas.

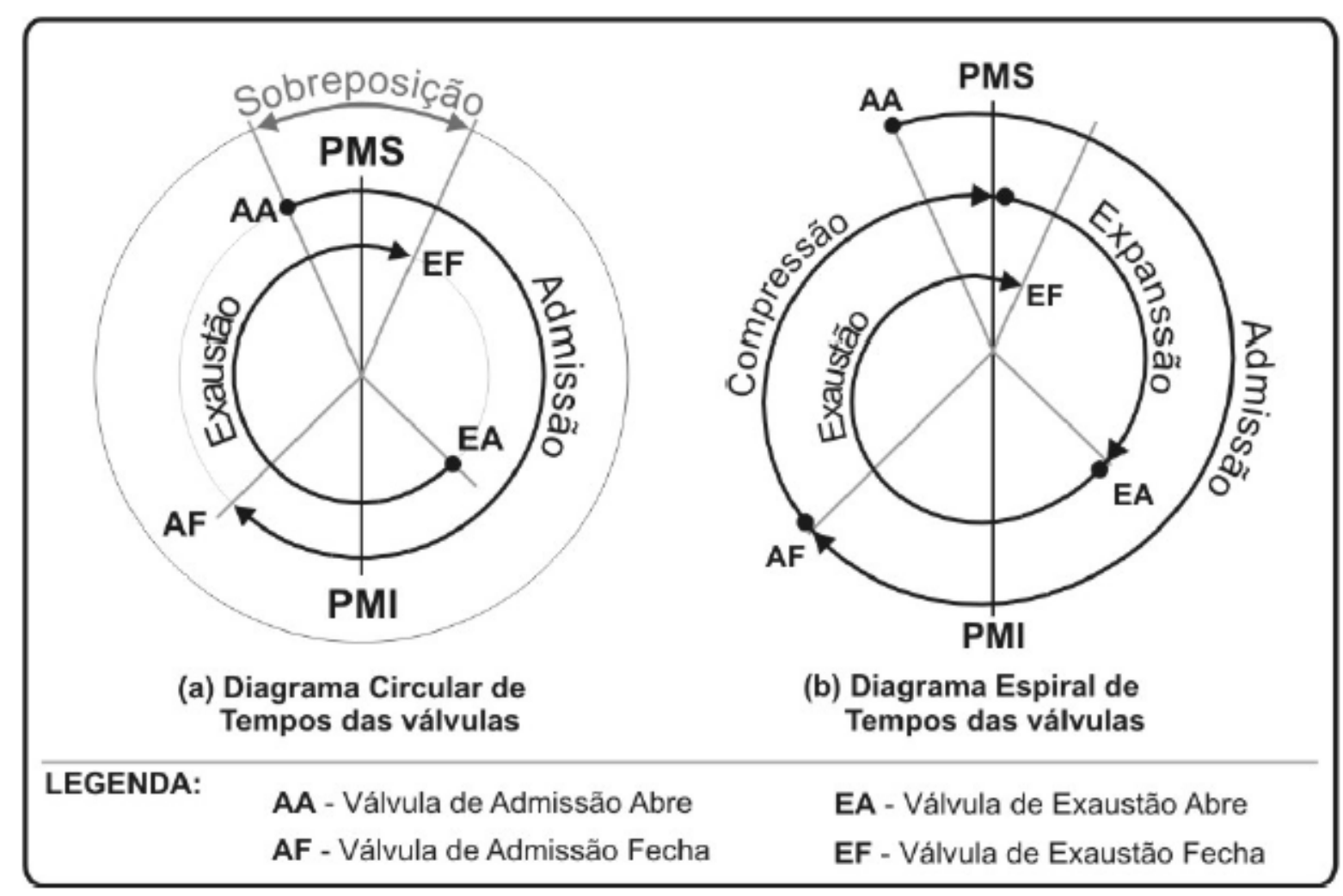

Fonte: Heisler (1995).

Quando os períodos de abertura das válvulas de admissão e exaustão são combinados em dois semicírculos tem-se o diagrama circular de tempos das válvulas, que pode ser observado na Figura 31(a). Quando os ciclos de admissão, compressão, expansão e exaustão são mostrados juntamente com os períodos de 
abertura das válvulas em um diagrama espiral contínuo, tem-se o diagrama espiral de tempos de válvulas ilustrado na Figura 31 (b).

O movimento angular do virabrequim que ocorre quando as válvulas de admissão ou exaustão abrem antes do PMS ou PMI, respectivamente, é comumente chamado de valve lead angle. O deslocamento antes das válvulas de admissão e exaustão fecharem depois do PMS e PMI, respectivamente, é denominado valve lag angle. O deslocamento angular total quando as válvulas de admissão e exaustão estão abertas simultaneamente na região do PMS é denominada overlap period. (FERGUSON; KIRKPATRICK, 2000; STONE, 1999; HEISLER, 1995). Essas sobreposições e atrasos serão analisadas adiante.

Uma melhor visualização da abertura e fechamento progressivo das válvulas de admissão e escape, a sobreposição e os tempos envolvidos pode ser conseguido através do diagrama de tempos e ângulos do virabrequim, Figura (32). O diagrama mostra, aproximadamente, que os primeiros $20^{\circ}$ de abertura e os últimos $20^{\circ}$ de fechamento das válvulas apresentam uma variação de curso mínima, porém, entre estes dois extremos o curso muda rapidamente.

Figura 32 - Diagrama de tempos - ângulos do virabrequim.

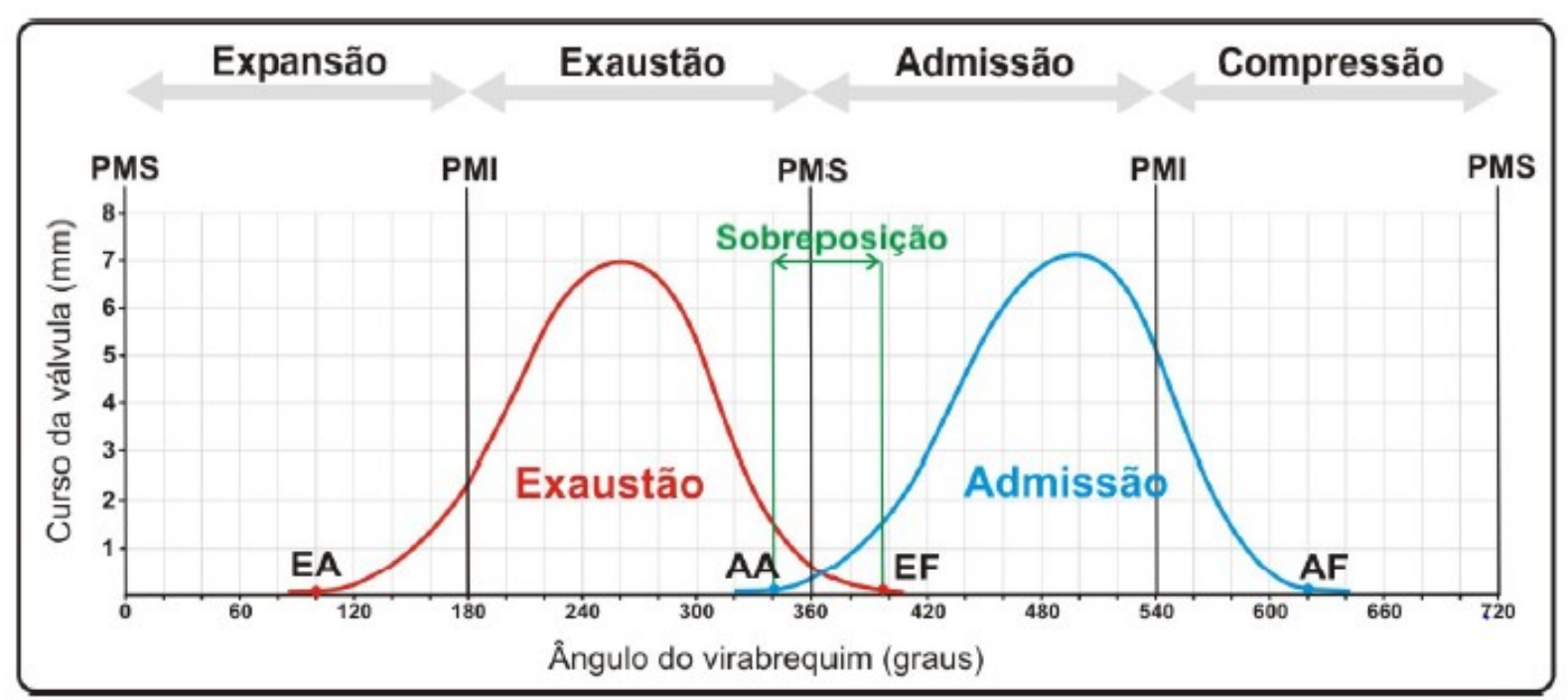

Fonte: Donaldson (2003). 


\subsubsection{Válvula de Exaustão}

Para tentar maximizar a saída dos gases de exaustão do cilindro, o came é projetado para abrir a válvula no momento em que o pistão reduz sua velocidade e se aproxima do PMI. Conseqüentemente, quando a válvula de exaustão se abre, os gases remanescentes no cilindro ainda apresentam uma pressão residual relativamente alta, em torno de 3 4 bar (300-400 kPa) o que provoca, pela própria ação da energia existente, a expulsão dos gases para o sistema de exaustão e para a atmosfera.

Por outro lado, esta abertura antecipada da válvula de exaustão provoca uma pequena perda no ciclo de expansão, que deve ser compensada pela energia economizada pela redução do trabalho no ciclo de exaustão, e também deve ser calculado de modo que a válvula se abra apenas quando o pistão estiver desacelerando na região próxima ao PMI.

A válvula de exaustão é mantida aberta durante todo o curso de exaustão e no início do curso de admissão, fechando logo após o PMS. O atraso no fechamento da válvula induz um vácuo na porta de exaustão e na câmara de combustão, proporcionando o melhor preenchimento desta com a nova mistura Ar/Combustível a ser queimada e facilitando o escoamento dos gases residuais ainda presentes no cilindro, como pode ser visualizado na Figura (33) a seguir (HEISLER, 1995). 
Figura 33 - Efeito da sobreposição em alta velocidade.

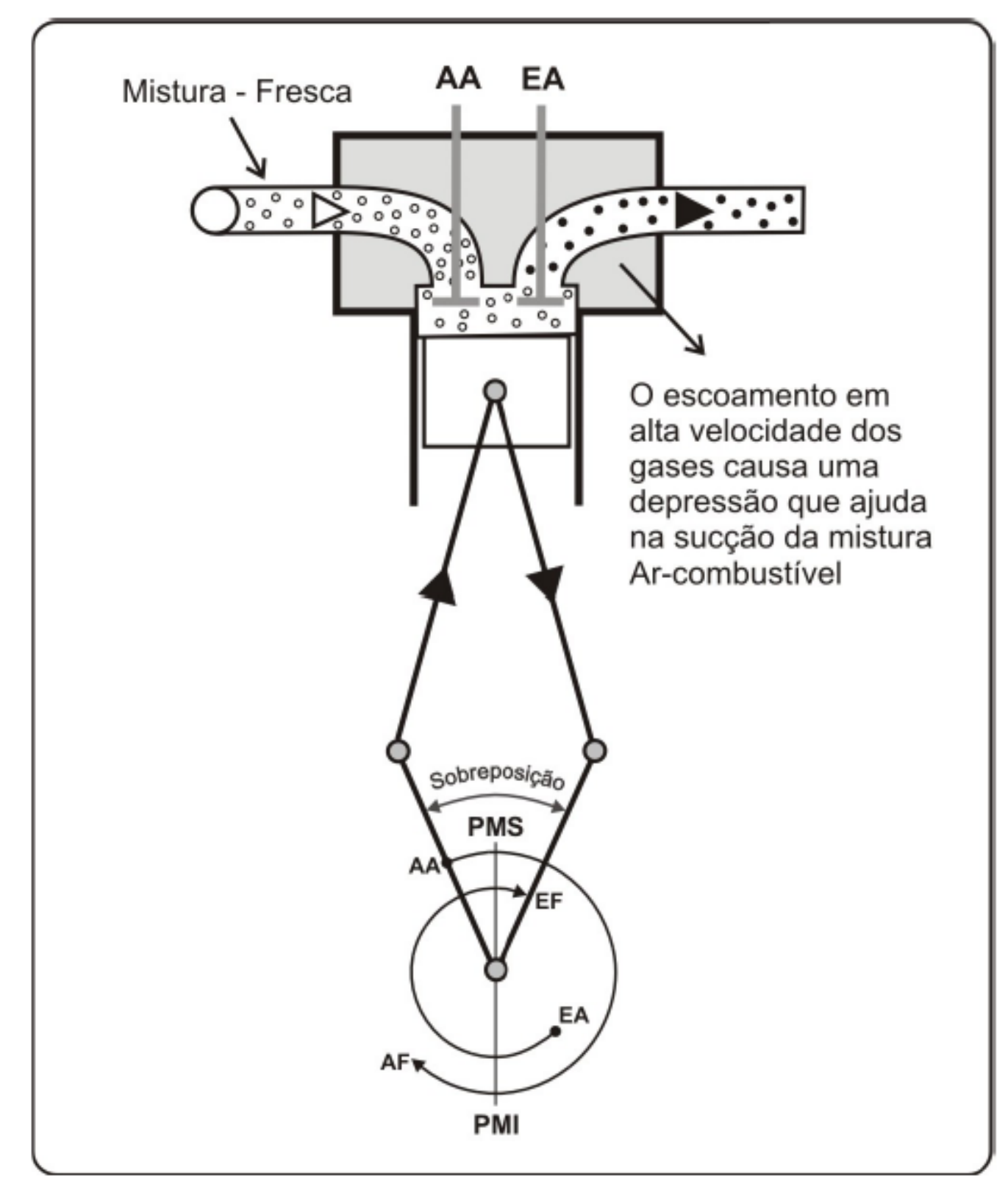

Fonte: Heisler (1995). 
2.9.2 Válvula de admissão

Para induzir a entrada de maior quantidade de mistura fresca para o interior do cilindro, a válvula de admissão deve iniciar seu curso de abertura no final do curso de exaustão, quando os gases que se encontram no cilindro ainda possuem energia cinética suficiente para provocar uma depressão na câmara de combustão. O seu escoamento em alta velocidade pela porta de escape, arrasta os gases remanescentes e induz ao preenchimento do cilindro com a nova mistura.

Por outro lado, se a válvula de admissão abre muito cedo no ciclo de exaustão, pressões ainda elevadas no cilindro podem induzir no escoamento do gás pela válvula de admissão até o coletor de admissão ao invés de escoar pelo sistema de exaustão.

A válvula de admissão permanece aberta durante todo o curso de admissão e parte do início do ciclo de compressão. O ângulo percorrido pelo virabrequim depois do PMI e antes que a válvula de admissão se feche é utilizado para o aproveitamento da inércia da nova mistura, proporcionando mais tempo para o preenchimento do cilindro e, conseqüentemente aumentando a densidade do carregamento, como ilustra a Figura (34) (HEISLER, 1995). 
Figura 34 - Efeito do atraso do fechamento da válvula de admissão em altas velocidades.

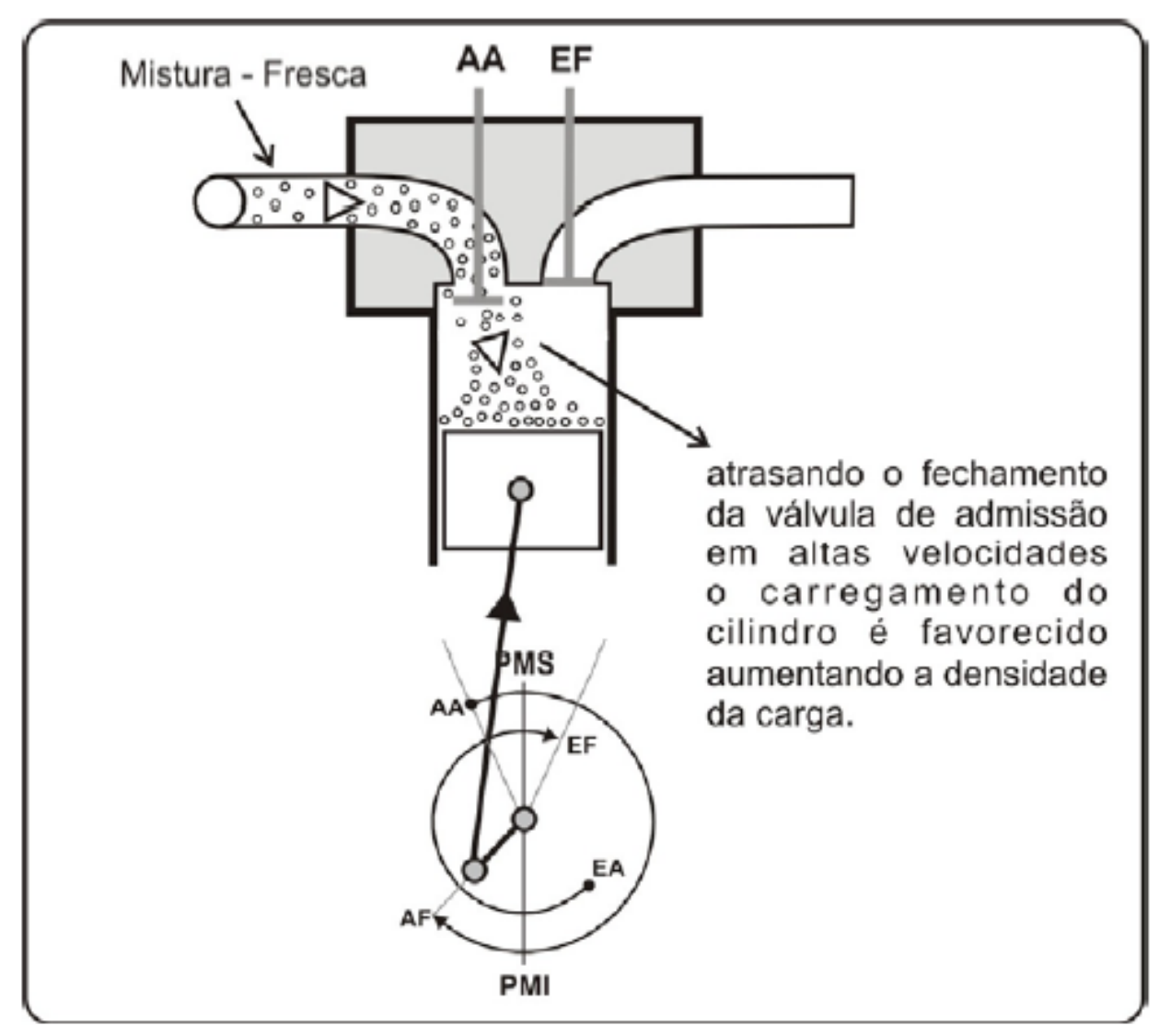

Fonte: Heisler (1995).

O atraso no fechamento da válvula de admissão até o ponto em que iniciase a compressão aumenta a eficiência volumétrica do cilindro para médias e altas rotações do motor; todavia, em baixas rotações, provoca uma densidade insuficiente para o preenchimento adequado do cilindro.

2.9.3 Limitações para a Sobreposição das Válvulas

Como já foi abordado, atrasar o fechamento da válvula de exaustão e adiantar a abertura da válvula de admissão resulta na abertura simultânea das duas válvulas ou sobreposição. 
A sobreposição permite o aumento da eficiência volumétrica do cilindro. É causado pelo escoamento dos gases de exaustão em alta velocidade, provocando uma depressão no cilindro que permite que a nova mistura preencha-o mais rapidamente, ocorrendo tanto nos motores ciclo Otto como ciclo Diesel.

Por outro lado, a estratégia de utilização da sobreposição conduz ao surgimento de efeitos negativos como o aumento da poluição causada pelos gases de exaustão, pois a depender da velocidade de operação, parte da mistura fresca é arrastada para fora do cilindro.

$\mathrm{Na}$ válvula de exaustão a sobreposição traz benefícios quando o motor está operando em altas rotações onde as perdas são menores. Quando a velocidade do motor é reduzida uma parcela da mistura será carregada juntamente com os gases da queima para o sistema de exaustão.

A perda de mistura Ar/combustível será tanto maior quanto menor for a velocidade do motor para uma dada sobreposição, assim como será tanto maior quanto for o atraso no fechamento da válvula. Conseqüentemente, será observado um aumento de hidrocarbonetos e de monóxido de carbono na composição dos gases de exaustão.

Três curvas que representam diferentes ângulos de atraso no fechamento da válvula, medidos em graus do virabrequim, a rotação do motor e o índice de emissões de hidrocarbonetos e monóxido de carbono podem ser analisados na Figura 35(a).

$\mathrm{Na}$ válvula de admissão, o efeito da sobreposição quando a válvula borboleta está parcialmente fechada faz com que a pressão no coletor de admissão diminua e isto pode ocorrer até que uma situação reversa ocorra entre o coletor e o cilindro, ou seja a pressão no coletor seja inferior à pressão no cilindro, fazendo com que os gases de exaustão escoem para o coletor de admissão. Conseqüentemente, já que a nova mistura vai ser diluída com os gases da queima diminuindo a quantidade de ar disponível na nova carga do cilindro, parte dos gases exauridos pelo escape não terá sofrido a completa combustão devido a falta de oxigênio, com conseqüência no aumento da quantidade de hidrocarbonetos e de monóxido de carbono na composição dos gases de exaustão aumentando as emissões para atmosfera, como pode ser visualizado na Figura (35(b)). (SELLNAU e RASK, 2003). 
Figura 35 - Emissão de gases para a atmosfera em função da sobreposição.

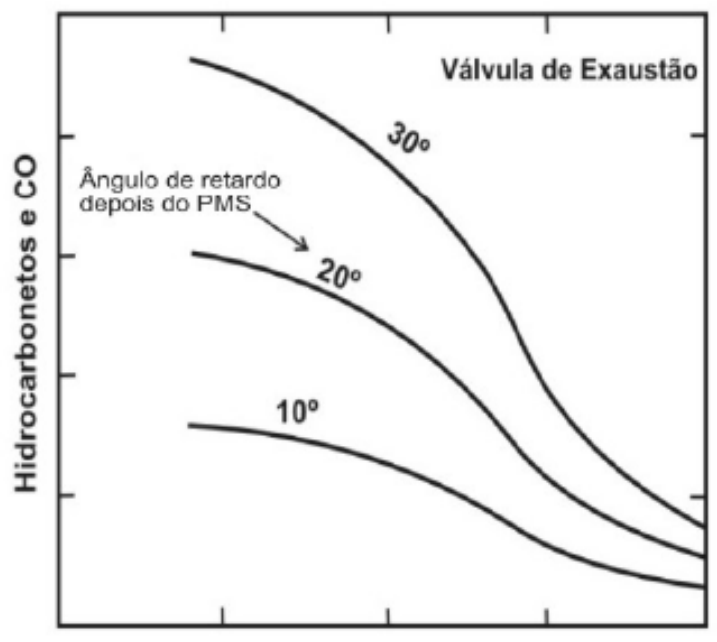

(a) Rotação do Motor (rpm)

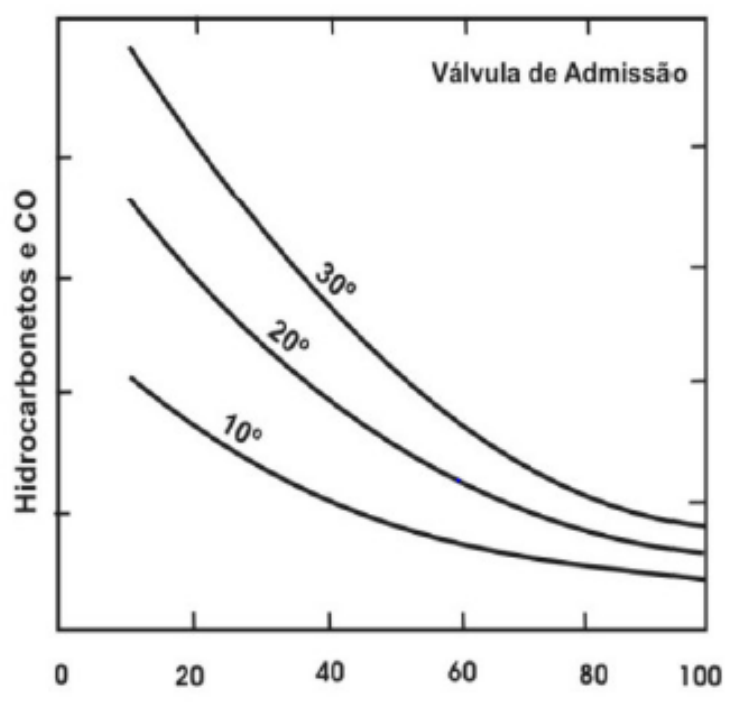

(b) Abertura da válvula de Controle (\%)

Fonte: Heisler (1995).

2.9.4 Tempos de Válvulas para Diferentes Aplicações

Os ângulos para abertura e fechamento de válvulas variam consideravelmente de acordo com a aplicação para a qual o motor foi projetado, neste sentido pode-se classificar os motores em quatro grandes categorias:

i. Motores de veículos leves: de pequeno porte, que trabalham em regimes de altas rotações com ciclo Otto ou Diesel.

ii. Motores de veículos de passageiros: de médio porte, que trabalham em regime de médias ou baixas rotações com ciclo Diesel ou Otto.

iii. Motores Industriais ou de aplicações marinhas: de grande porte que trabalham em regime de baixas rotações com ciclo Diesel.

iv. Motores de competição e corrida: altas rotações com ciclo ignição por faísca.

A grande maioria dos motores com ciclo Otto ou Diesel utilizados na atualidade, sejam eles estacionários ou veiculares, podem ser enquadrados no diagrama de tempos de válvulas da Figura 36. 
Figura 36 - Diagrama de tempos para diversos motores.

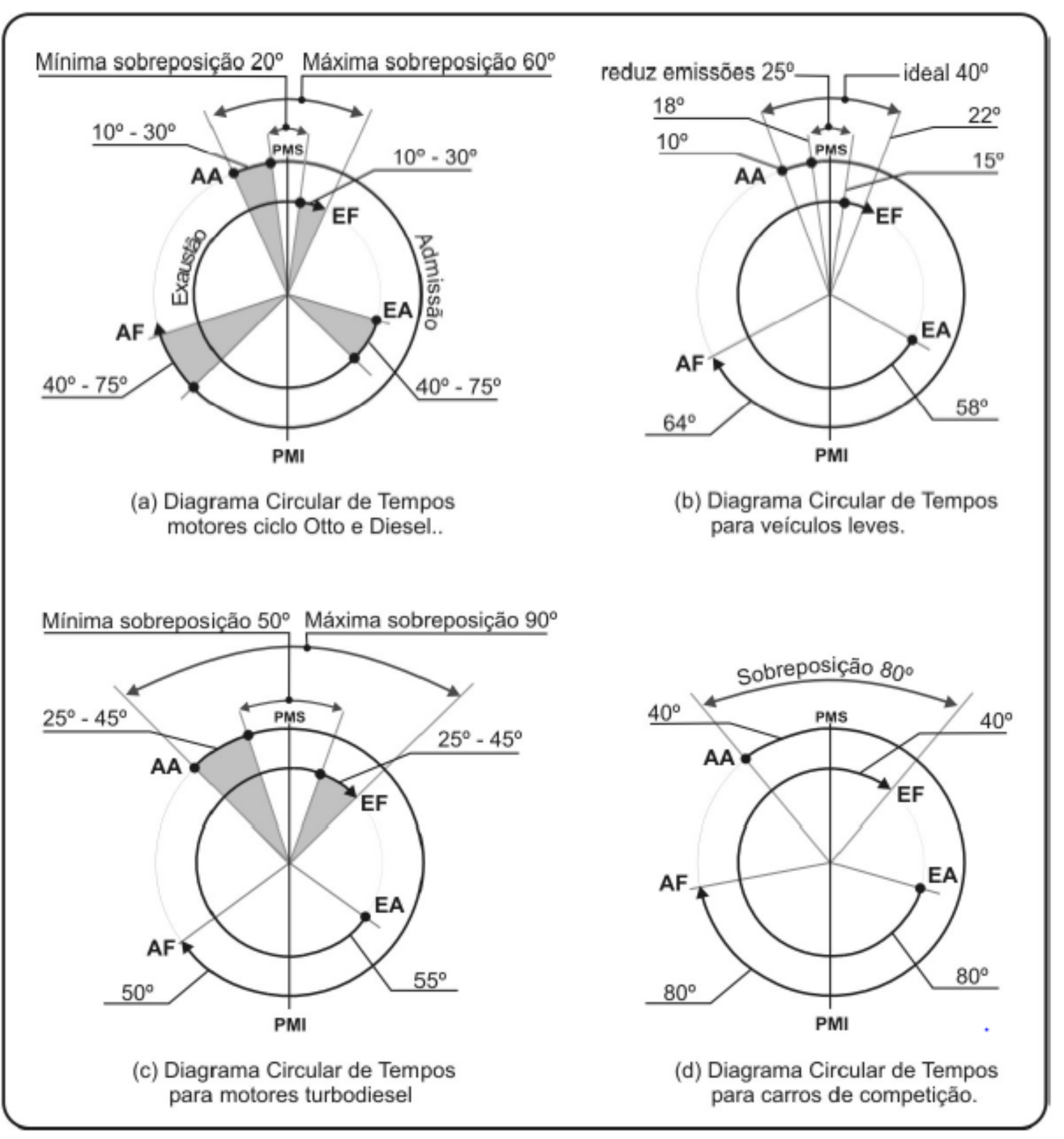

Fonte: Heisler (1995).

O diagrama de tempos típico para veículos Figura 36(b), mostra a abertura e fechamento da válvula de admissão em $18^{\circ}$ antes do PMS e $64^{\circ}$ depois do PMI, respectivamente. A válvula de exaustão opera tipicamente abrindo $58^{\circ}$ antes do PMI e fecha $22^{\circ}$ depois do PMS. Isto proporciona uma sobreposição de $40^{\circ}$. Visando reduzir as emissões, pode-se verificar nos modelos atuais, a abertura da válvula de 
admissão em torno de $15^{\circ}$ e fechamento da válvula de exaustão em torno de $25^{\circ}$, perfazendo uma sobreposição de $25^{\circ}$. Esta estratégia diminui as emissões sem comprometer o desempenho do motor.

Os Motores de ciclo diesel pelo fato de não possuírem o controle de ar na entrada do cilindro não são susceptíveis à poluição causada pela sobreposição de válvulas, por isso podem ser beneficiados pelo atraso no fechamento da válvula de admissão. Motores turbodiesel podem ser beneficiados tanto pelo atraso no fechamento da válvula de admissão, quanto pelo adiantamento na abertura da válvula de admissão. A sobreposição pode ser estendida até limites operacionais que não permitam o escoamento de gases de exaustão pelo coletor de admissão ou prejudiquem o preenchimento do cilindro. Estes motores são normalmente utilizados para veículos de passageiros, e os tempos típicos destes tipos de motores são ilustradas na Figura 36 (c).

Motores de competição naturalmente aspirados com ciclo Otto, que operam em altas rotações, podem tirar proveito da extrapolação dos limites de fechamento e abertura das válvulas de exaustão e admissão, Figura 36 (c). Isto ocorre devido à falta de compromisso com o consumo de combustível e emissões para atmosfera. Para estes motores os parâmetros típicos são mostrados na Tabela 2.

Tabela 2 - Parâmetros típicos de motores ciclo Diesel e ignição por centelha.

\begin{tabular}{|c|l|c|c|c|}
\cline { 3 - 4 } \multicolumn{2}{l|}{} & $\begin{array}{c}\text { Motores ciclo } \\
\text { Diesel de } \\
\text { médio porte }\end{array}$ & $\begin{array}{c}\text { Motores de } \\
\text { veículos leves } \\
\text { de ignição por } \\
\text { faísca }\end{array}$ & $\begin{array}{c}\text { Motores de } \\
\text { competição de } \\
\text { ignição por } \\
\text { faísca }\end{array}$ \\
\hline $\begin{array}{c}\text { Válvula de } \\
\text { Admissão }\end{array}$ & $\begin{array}{l}\text { Abertura antes } \\
\text { do PMS }\end{array}$ & $25^{\circ}-45^{\circ}$ & $10^{\circ}-18^{\circ}$ & $40^{\circ}$ \\
\cline { 2 - 5 } & $\begin{array}{l}\text { Fechamento } \\
\text { após o PMl }\end{array}$ & $50^{\circ}$ & $64^{\circ}$ & $80^{\circ}$ \\
\hline $\begin{array}{l}\text { Válvula de } \\
\text { Exaustão }\end{array}$ & $\begin{array}{l}\text { Abertura antes } \\
\text { do PMI }\end{array}$ & $55^{\circ}$ & $58^{\circ}$ & $80^{\circ}$ \\
\cline { 2 - 5 } & $\begin{array}{l}\text { Fechando após } \\
\text { PMS }\end{array}$ & $25^{\circ}-45^{\circ}$ & $15^{\circ}-22^{\circ}$ & $40^{\circ}$ \\
\hline
\end{tabular}

Fonte: Heisler (1995). 


\subsubsection{Balancins}

O balancim é usado para transferir o movimento do comando de came para as válvulas. Ele funciona como uma alavanca, multiplicando o movimento do comando para a válvula e desta forma exige um levante do comando menor em relação aos modelos com tuchos, já que seu deslocamento será multiplicado em virtude da sua relação de multiplicação. Segundo Lima (2018) normalmente as razões de multiplicação são de 1.2:1 e 1.4:1 e são fabricados geralmente em ferro fundido, aço estampado, aço forjado e alumínio. Com a alteração deste fator de multiplicação pode-se ter um melhor fluxo em todo o diagrama de válvulas sem a troca do comando de válvulas e sem o deslocamento da faixa de rotação do motor. A regulagem da folga de válvula nos sistemas com balancins e feito de forma mecânica normalmente através de uma rosca. (LIMA, 2018).

\subsubsection{Tuchos}

Nos sistemas de distribuição com tuchos as válvulas são acionadas diretamente ou através de balancins. O came realiza o acionamento diretamente pela face externa do fundo do tucho. Estes sistemas de atuação direta se destacam pela sua maior rigidez e baixa massa móvel garantindo um excelente desempenho em altas rotações. Nos sistemas que usam os tuchos a folga de válvula é feita através de discos de ajustes com diferentes espessuras. (SCHAEFFLER BRASIL LTDA, 2011).

\subsubsection{Molas das válvulas}

Segundo Lima (2018) as molas são responsáveis pelo controle de movimento de abertura e fechamento das válvulas de admissão e escapamento. Molas originais possuem uma carga suficiente para atingirem elevadas rotações por minuto (rpm) sem apresentar o efeito de flutuação ou fadiga. A flutuação das válvulas faz com que as válvulas permaneçam abertas quando deveriam estar fechadas, ocasionando perdas de desempenho e correndo risco das válvulas se 
chocarem com o pistão quando este estiver no PMS. A escolha da carga de mola depende do comando usado e qual velocidade de rotação o motor irá atingir, uma escolha de mola com carga muito alta além de consumir potência do motor ainda poderá ocasionar danos nos cames do comando e em casos mais severos nas válvulas e cabeçote. 


\section{METODOLOGIA}

Com o objetivo de identificar e analisar mudanças no comportamento de um motor de dois cilindros sobrealimentado, de acordo com as dimensões dos dutos responsáveis pela condução da carga de ar para os cilindros, foi utilizado um dinamômetro de rolos modelo 2025 da fabricante Servitec. O motor utilizado para análise foi o de uma motocicleta Yamaha R3 modelo 2016, nas condições evidenciadas na Tabela 3.

Tabela 3 - Condições de testes no dinamômetro.

\begin{tabular}{|c|c|c|}
\hline Condições do motor & $\begin{array}{c}\text { Condições de } \\
\text { escoamento }\end{array}$ & Combustível \\
\hline $\begin{array}{c}\text { Naturalmente aspirado, em condições } \\
\text { originais na motocicleta }\end{array}$ & $\begin{array}{c}\text { Sistema de admissão e } \\
\text { exaustão originais }\end{array}$ & Gasolina E27 \\
\hline Naturalmente aspirado, acoplado no \\
prototipo EK304 & Com restritor & Etanol \\
\cline { 2 - 3 } & Sem restritor & Etanol \\
\hline \multirow{2}{*}{$\begin{array}{c}\text { Sobrealimentado, acoplado no protótipo } \\
\text { EK 304 (turbocompressor IHI RHB 31) }\end{array}$} & Com restritor & Etanol \\
\cline { 2 - 3 } & Sem restritor & Etanol \\
\hline
\end{tabular}

Fonte: Elaboração própria.

Com o intuito de comparar os modelos físicos com um modelo computacional, se faz necessária a obtenção de pelo menos a potência e torque aferidos em relação ao número de rotações do motor, sendo assim o dinamômetro uma ferramenta capaz para atender essas necessidades. Para esse tipo de medição seria ideal a utilização de um dinamômetro de bancada - aferição de torque a partir do próprio motor, todavia devido à falta de disponibilidade de tal equipamento, foi utilizado um dinamômetro de rolos - a medição é feita a partir das rodas do veículo, contudo, a aquisição de dados desse método conta com as perdas de transmissão 
do sistema como um todo. Para o uso de um dinamômetro de rolos, é necessária a fixação e travamento da estrutura do veículo de forma que garanta a segurança e evite acidentes. Os procedimentos aqui citados se repetiram tanto para os testes realizados com a motocicleta original como com o protótipo EK304. Para manter o veículo estático, foram utilizadas 4 cintas em poliéster que satisfazem as normas ABNT NBR 15637-1 e Europeia EN 1492-1, com coeficiente de segurança de 7:1 e com carga máxima de 2 toneladas. Essas cintas foram engastadas tanto no solo (em engates próprios para esse tipo de fixação) quanto na parte frontal e posterior da estrutura. Além disso, foi providenciado um ventilador capaz de simular as condições de resfriamento dos radiadores e do intercooler do motor com o veículo em movimento - considerando que no caso estudado é um ambiente fechado sem fluxo de ar para resfriamento. Tanto o procedimento de fixação das cintas, quanto o ventilador mencionado podem ser vistos na Figura 37.

Figura 37 - Fixação do protótipo no dinamômetro.

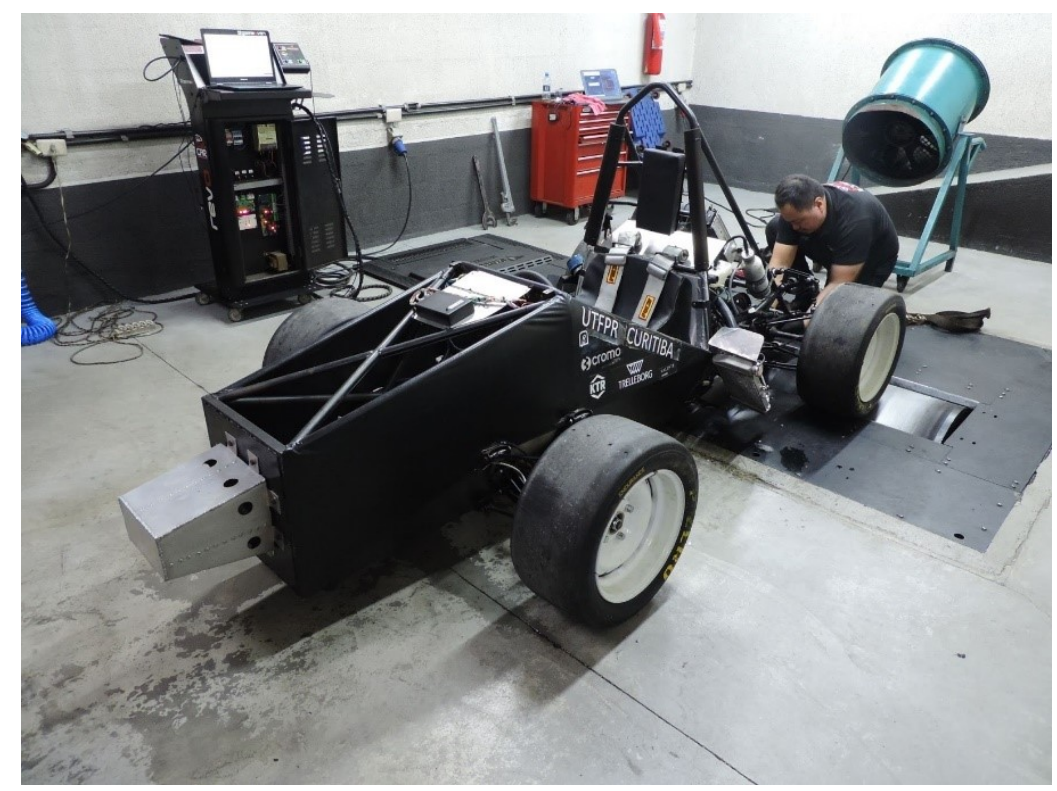

Fonte: Elaboração própria.

Após o devido travamento e certificação da fixação correta do veículo, os sistemas de calibração, injeção e ignição do protótipo foram testados e calibrados para as condições de uso, conforme evidenciado nas Figuras 38 e 39. 
Figura 38 - Calibração do sistema de injeção e ignição do protótipo.

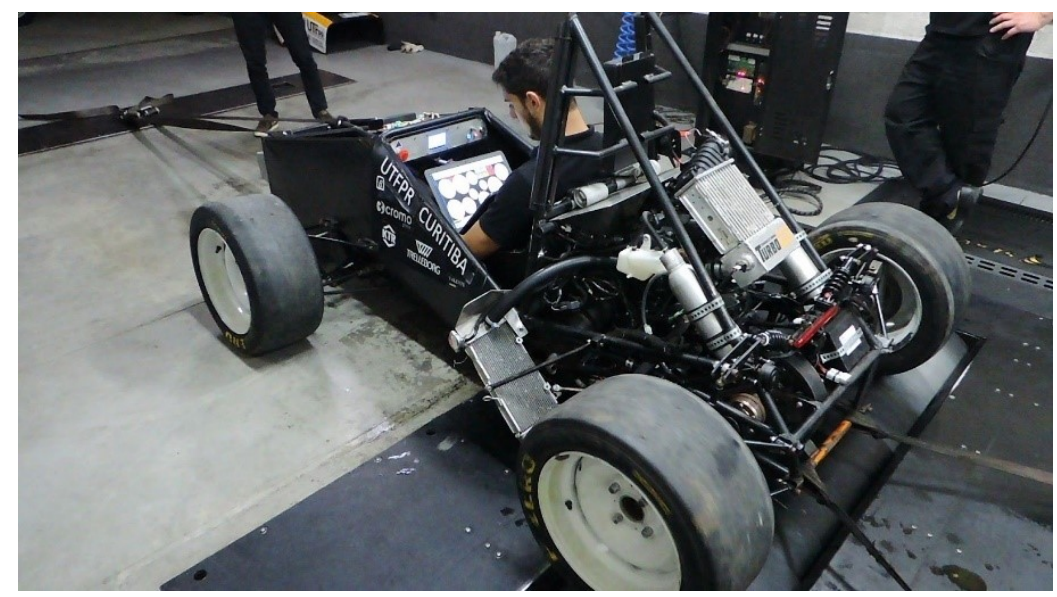

Fonte: Elaboração própria.

Figura 39 - Calibração do sistema de injeção e ignição do protótipo.

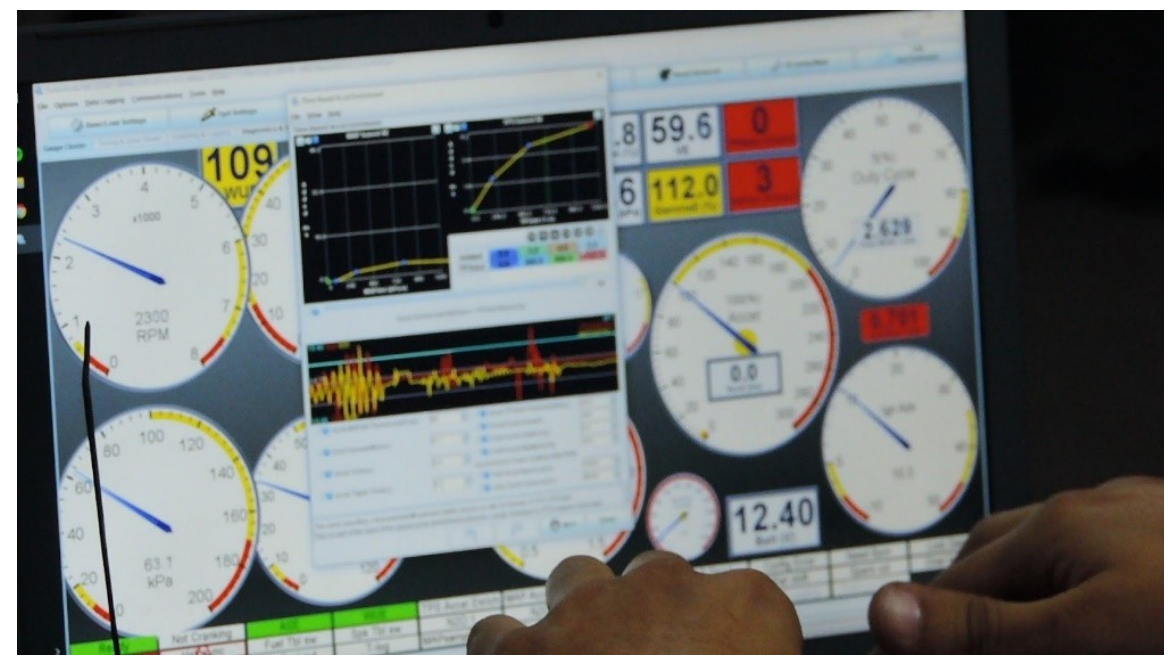

Fonte: Elaboração própria.

A calibração foi realizada com passadas de teste pelo dinamômetro, levantando-se as curvas de potência e torque do motor nas condições já descritas na Tabela 4. Ao todo foram necessárias 60 passagens com o protótipo e $9 \mathrm{com}$ a moto em condições originais, sendo que 30 passagens foram necessárias para calibração de injeção e ignição do protótipo até atingir as condições esperadas de 
funcionamento. A Figura 40 mostra o veículo em funcionamento durante uma passagem no dinamômetro, com as cintas de segurança.

Figura 40 - Teste no dinamômetro.

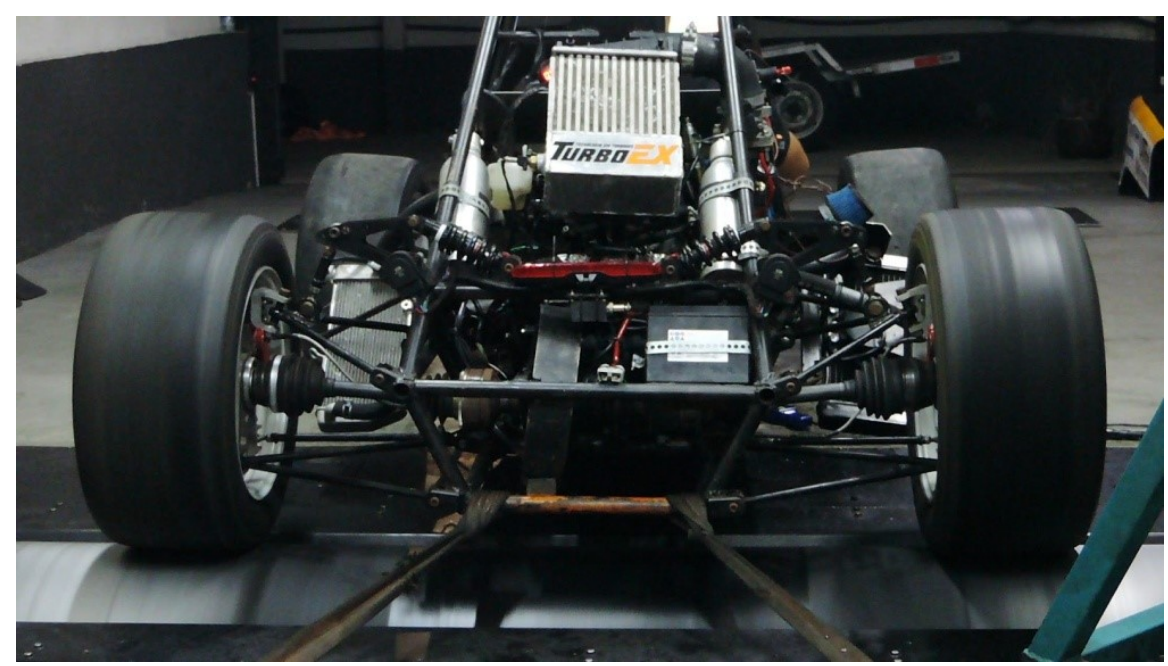

Fonte: Elaboração própria.

Ademais, em conjunto com os experimentos, espera-se comparar os resultados coletados com modelos matemáticos calculados via software Ricardo Wave, de modo a validar o comportamento dos fenômenos estudados. A fim de ser replicada corretamente no modelo, algumas dimensões do motor precisaram ser mensuradas fisicamente para serem representadas de forma a equiparar as condições de contorno gerais do motor, como, por exemplo: diâmetro e curso dos pistões, comprimento das bielas, taxa de compressão, diâmetro e comprimento dos dutos de admissão e exaustão, combustível utilizado e dados dos mapas do turbocompressor. A simulação é realizada para uma dada situação de alguns parâmetros como rotação, proporção ar combustível e avanço de ignição. Com o intuito de se "replicar" a curva de um dinamômetro, foram realizadas diversas simulações variando a rotação, para então, gerar um gráfico que seja equiparável aos resultados obtidos nos testes em função da rotação do motor.

Com relação ao modelo virtual do motor no Ricardo Wave, foi gerado um conjunto de dados de componentes de fluxo e mecânicos conforme, categorizados e nomeados na Tabela 4 para facilitar a transposição para o software. 
Tabela 4 - Dados utilizados nas simulações no software Ricardo Wave.

\begin{tabular}{|c|c|c|}
\hline Componente & $\begin{array}{l}\text { Nome no } \\
\text { Software }\end{array}$ & Dimensões principais \\
\hline Dutos de admissão & $\begin{array}{l}\text { ADM_DUT_A_1 } \\
\text { ADM_DUT_A_2 }\end{array}$ & $\begin{array}{c}\qquad 26 \mathrm{~mm} \times 206 \mathrm{~mm} \\
\text { (bicos injetores nos primeiros } 15 \mathrm{~mm} \text { de } \\
\text { dutos) }\end{array}$ \\
\hline Bicos injetores & INJ_1 e INJ_2 & ${ }^{*}$ Controlado pela vazão \\
\hline $\begin{array}{c}\text { Bifurcação da admissão para as } \\
\text { válvulas }\end{array}$ & $\begin{array}{l}\text { ADM_BIF_A } \\
\text { ADM_BIF_B }\end{array}$ & $\varnothing 26 \mathrm{~mm} \times 10 \mathrm{~mm}$ \\
\hline Dutos de admissão de cada válvula & $\begin{array}{l}\text { ADM_DUT_A_A_1 } \\
\text { ADM_DUT_A_B_1 } \\
\text { ADM_DUT_B_A_1 } \\
\text { ADM_DUT_B_B_1 }\end{array}$ & $\varnothing 20 \mathrm{~mm} \times 90 \mathrm{~mm}$ \\
\hline Válvulas de admissão & $\begin{array}{l}\text { ADM_VALV_A_A } \\
\text { ADM_VALV_A_B } \\
\text { ADM_VALV_B_A } \\
\text { ADM_VALV_B_B }\end{array}$ & $\begin{array}{l}\qquad \varnothing 20 \mathrm{~mm} \\
\text { Perfil medido com relógio comparador }\end{array}$ \\
\hline Cilindros & $\begin{array}{l}\text { ClL_A } \\
\text { ClL_B }\end{array}$ & $\begin{array}{c}2 \text { válvulas de admissão } \\
2 \text { válvulas de exaustão } \\
\varnothing 68 \mathrm{~mm} \times 44,1 \mathrm{~mm} \\
\text { Comprimento da biela: } 117 \mathrm{~mm}\end{array}$ \\
\hline Válvulas de exaustão & $\begin{array}{l}\text { EX_VALV_A_A } \\
\text { EX_VALV_A_B } \\
\text { EX_VALV_B_A } \\
\text { EX_VALV_B_B }\end{array}$ & $\begin{array}{l}\qquad \varnothing 18,28 \mathrm{~mm} \\
\text { Perfil medido com relógio comparador }\end{array}$ \\
\hline Dutos de exaustão de cada válvula & $\begin{array}{l}\text { EX_DUT_A_A_1 } \\
\text { EX_DUT_A_B_1 } \\
\text { EX_DUT_B_A_1 } \\
\text { EX_DUT_B_B_1 }\end{array}$ & $\varnothing 18,38 \mathrm{~mm} \times 90 \mathrm{~mm}$ \\
\hline
\end{tabular}




\begin{tabular}{|c|c|c|}
\hline $\begin{array}{c}\text { Bifurcação das válvulas para a } \\
\text { exaustão }\end{array}$ & $\begin{array}{c}\text { EX_BIF_A } \\
\text { EX_BIF B }\end{array}$ & $\varnothing 26 \mathrm{~mm} \times 10 \mathrm{~mm}$ \\
\hline Dutos de exaustão & $\begin{array}{c}\text { EX_DUT_A_1 } \\
\text { EX_DUT_A_2 }\end{array}$ & $\begin{array}{c}\text { (Orifício de restrição de fluxo) } \\
\varnothing 28 \mathrm{~mm} \times \text { x 30mm }\end{array}$ \\
\hline Bifurcação final para exaustão & EX_BIF & $\varnothing 38 \mathrm{~mm} \times 10 \mathrm{~mm}$ \\
\hline Duto de exaustão final & EX_DUT_1 & $\varnothing 38 \mathrm{~mm} \times 345 \mathrm{~mm}$ \\
\hline
\end{tabular}

Fonte: Elaboração própria.

Após a geração e organização dos nomes, os componentes foram inseridos no Ricardo Wave, e sua visualização geral está demonstrada na Figura 41.

Figura 41 - Layout geral do motor da R3 sem restritor no software Ricardo Wave.

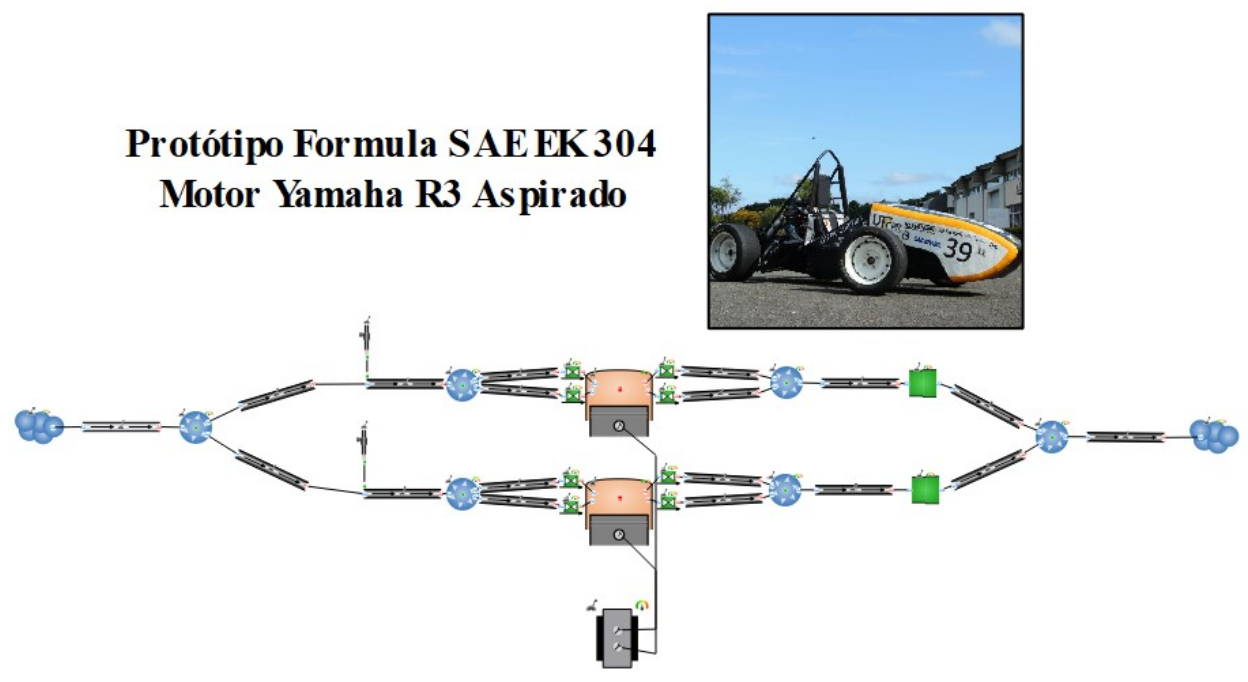

Fonte: Elaboração própria. 
Os dados das dimensões dos cilindros foram adquiridos por meio de tabelas técnicas e medições físicas no motor. Esses dados estão denotados na Figura 42. Para as condições iniciais, foram medidas as temperaturas em diferentes regiões do motor em funcionamento nas rotações baixas após seus valores estabilizarem. Para a pressão atmosférica e temperatura da massa de ar, foram utilizados os valores de 1 bar e $300 \mathrm{~K}$, respectivamente. Os combustíveis utilizados são os mesmos evidenciados no quadro 1 para cada análise efetivada.

Figura 42 - Dados do cilindro no software Ricardo Wave.

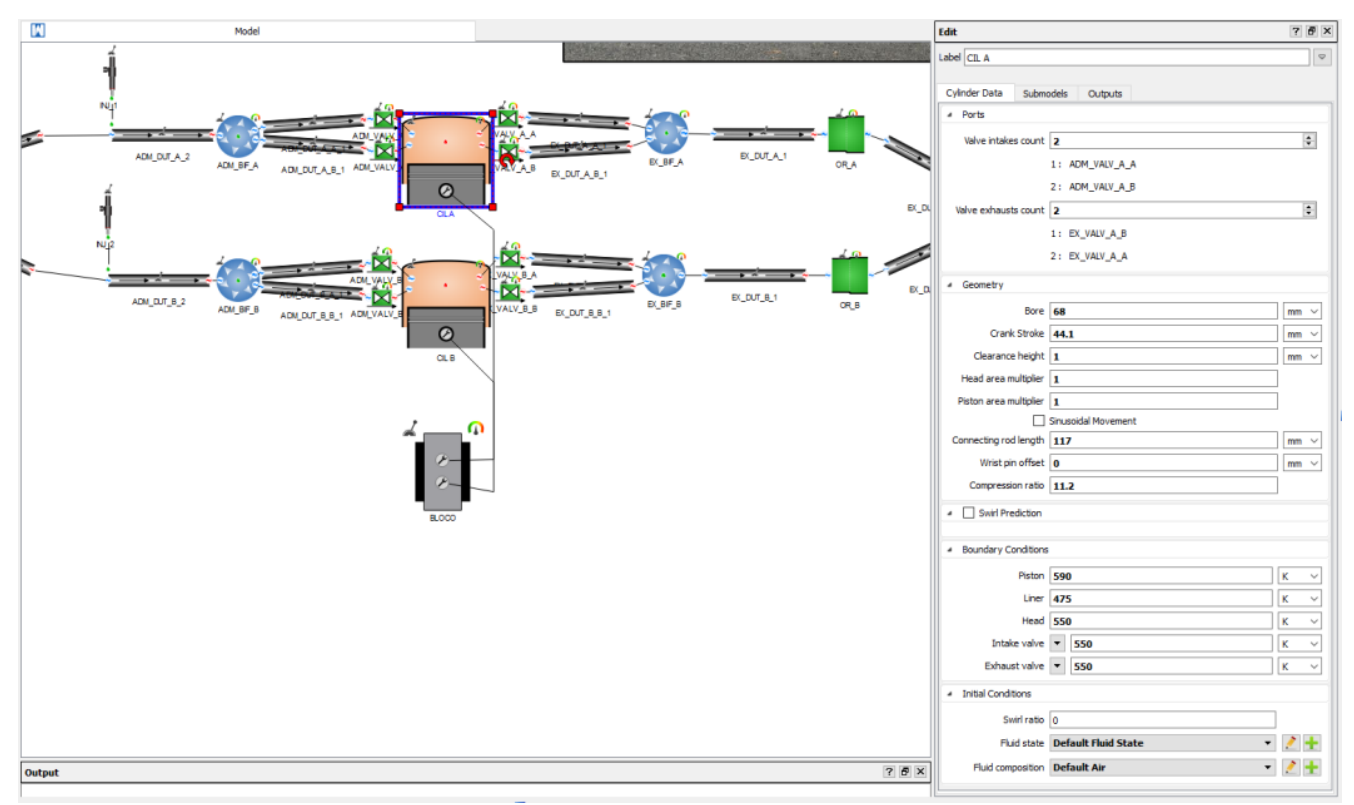

Fonte: Elaboração própria.

Tendo todos os dados requeridos pelo software, foi possível fazer a simulação computacional 1D da operação do motor. Para isso foi utilizado o mesmo intervalo de rotações escolhido para os testes no dinamômetro (de 3000 RPM a 12500 RPM), com um passo de 500 RPM. O solver do Ricardo Wave foi configurado para a extração dos gráficos de potência, torque, pressão média efetiva, temperatura na admissão e pressão na admissão (todos em relação à rotação do motor). Os dados do dinamômetro foram extraídos e plotados inicialmente utilizando o software 
WinSSDino, disponível para uso gratuito com os dinamômetros da Servitec. Dessa maneira foi possível elaborar uma comparação inicial entre as curvas experimentais e o motor simulado no software. A curva no dinamômetro está evidenciada na Figura 43 e a curva inicial plotada no Ricardo Wave está na Figura 44.

Figura 43 - Dados do motor sem restritor no dinamômetro.

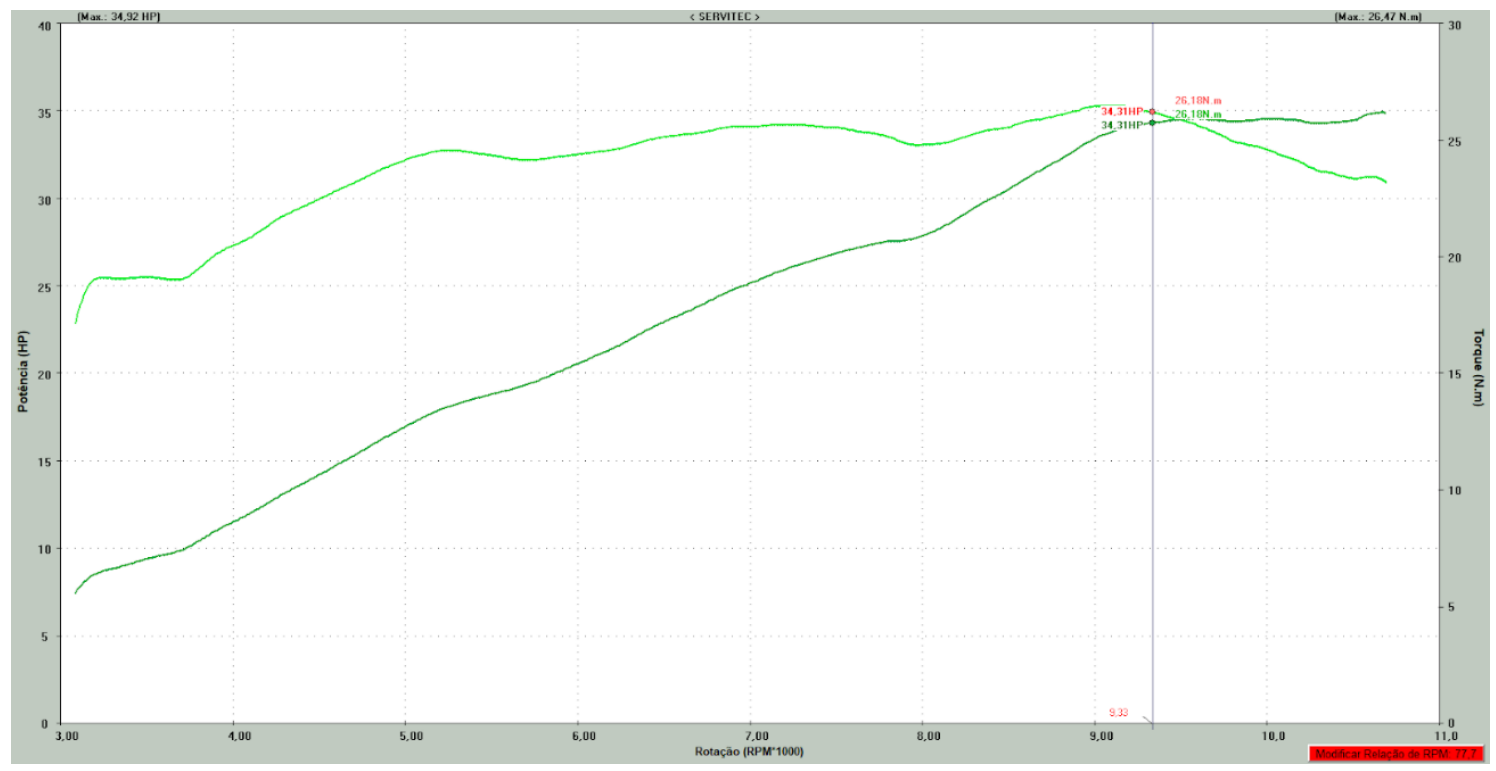

Fonte: Elaboração própria. 
Figura 44 - Dados computacionais do motor sem restritor simulado no software Ricardo Wave.

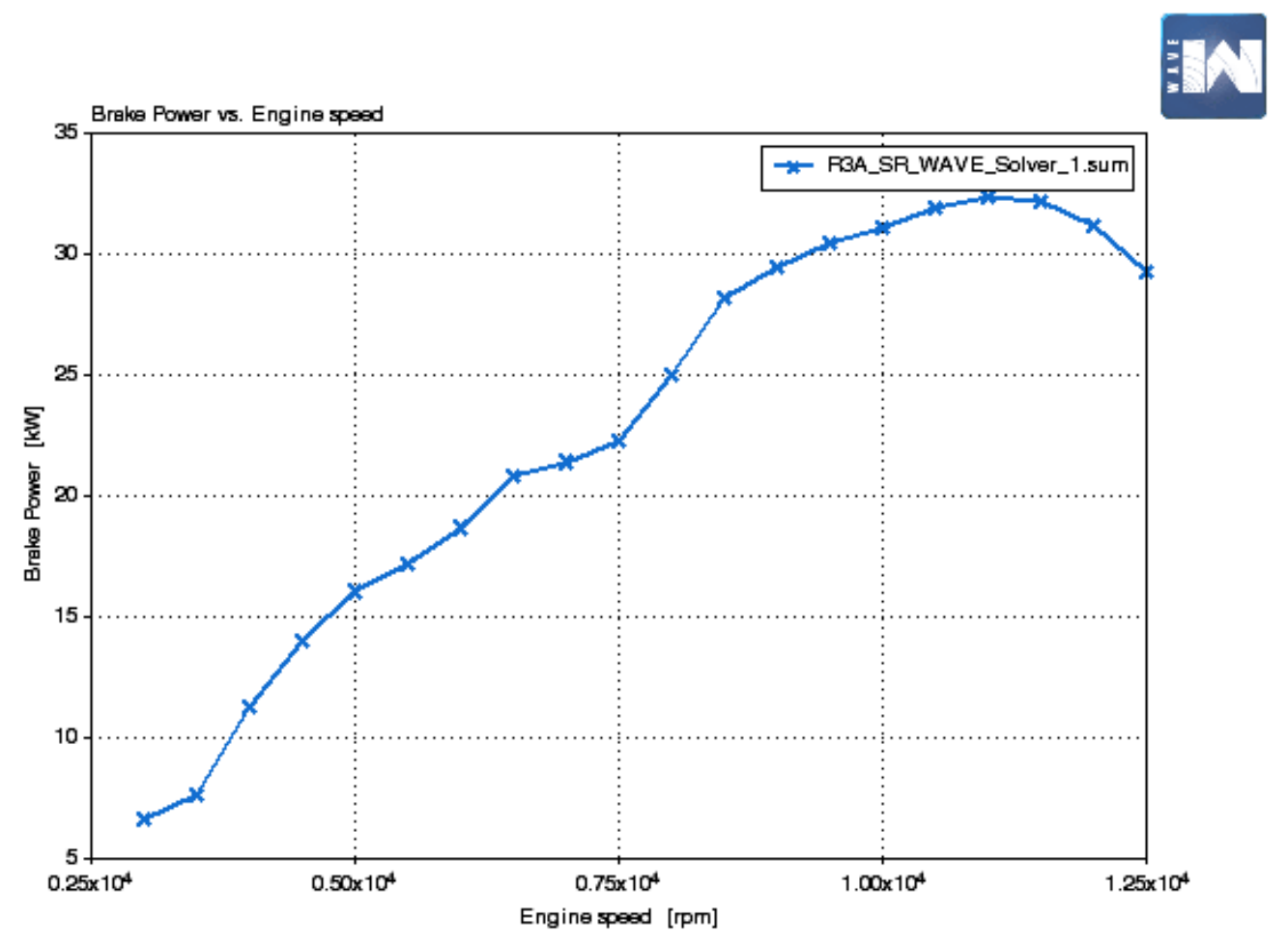

Fonte: Elaboração própria.

Todavia, como esses gráficos são de difícil comparação nesse estado apresentado, os dados foram exportados para o excel com o objetivo de flexibilizar a plotagem, ajustar as escalas com liberdade e padronizar a formatação dos dados, assim tornando a visualização e comparação mais prática e facilitada.

Adicionalmente, foi elaborado o layout de motor, apresentado na Figura 45, com o restritor de ar instalado no duto de admissão, com o objetivo de comparar o comportamento do motor aspirado com e sem restritor. Para isto, foi utilizada uma redução de diâmetro de $\varnothing 75 \mathrm{~mm}$ até $\varnothing 19 \mathrm{~mm}$ em um comprimento de $75 \mathrm{~mm}$, e depois um aumento de $\varnothing 19 \mathrm{~mm}$ até $\varnothing 75 \mathrm{~mm}$ em um comprimento de $75 \mathrm{~mm}$. 
Figura 45 - Dados do restritor no software Ricardo Wave.

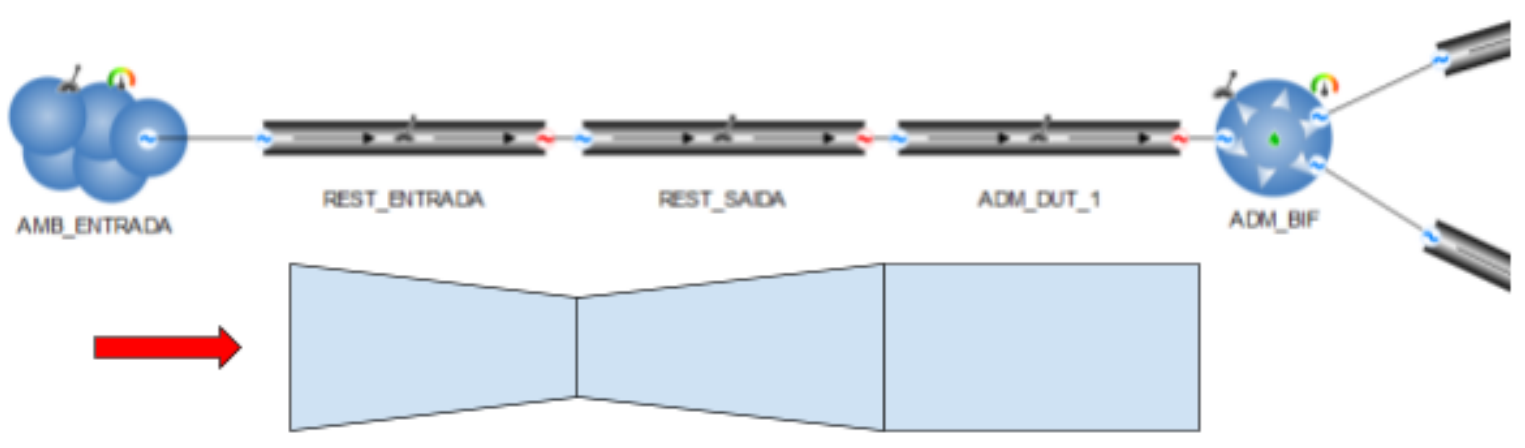

Fonte: Elaboração própria.

Além do motor com e sem restritor, com o objetivo de validar os dados oriundos das simulações computacionais realizadas no WAVE, foi elaborado um layout computacional do motor sobrealimentado, para comparação e validação do motor nessas condições reais. Esse layout está disposto na Figura 46 e conta com os elementos adicionais de compressor de ar, turbina, eixo de ligação, controlador da wastegate da turbina a partir da tomada de pressão após o compressor de ar.

Figura 46 - Dados computacionais do motor sobrealimentado simulado no Wave.

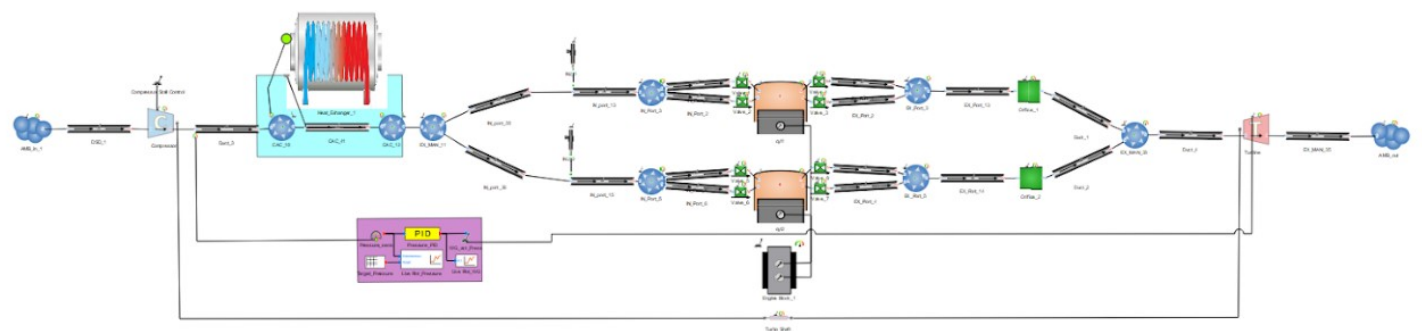

Fonte: Elaboração própria. 
Para o motor no estado sobrealimentado, também foram necessárias configurações em relação ao mapa do compressor.

Para todos os casos simulados, foi tentado aproximar-se ao máximo das condições reais do motor no dinamômetro. Dessa maneira, para as condições em que o combustível era gasolina, no WAVE foi utilizado o indolene por ser a configuração predeterminada mais próxima do real, e para as condições em que o combustível era etanol, foi utilizado este mesmo combustível por estar disponível no software.

Em relação ao método para o cálculo da combustão nos cilindros, foi utilizada uma única função de Wiebe, e os pontos de calibração correspondentes de $50 \%$ e $100 \%$ da massa de combustível queimada no cilindro foram regulados de acordo com as rotações, variando, respectivamente, de 2 a 10 e de 25 a 45 graus de giro do virabrequim.

Para os comprimentos de discretização ao longo dos dutos, foi utilizado um valor padrão de $10 \mathrm{~mm}$ tanto para a admissão quanto para a exaustão. Foram considerados um total de 30 ciclos para cada rotação (até os valores convergirem).

No caso das condições iniciais de fluidos, foi considerado um valor de 1 bar para a pressão e $300 \mathrm{~K}$ para a temperatura (com velocidade inicial de $0 \mathrm{~m} / \mathrm{s}$ ). Isso se deu por conta de que mesmo que a pressão em Curitiba não seja exatamente 1 bar, quando testado o veículo no dinamômetro, os gráficos plotados, foram considerados um fator de correção da norma SAE J1349. O coeficiente final segundo a norma ficou em 1,14 para o estudo naturalmente aspirado e 1,044 para o estudo com a sobrealimentação.

Para a injeção de combustível, os injetores foram posicionados fora dos cilindros, nos dutos de admissão antes da bifurcação final para as válvulas assim como se encontra o empacotamento do motor fisicamente. Para satisfazer essa condição, foi utilizado um injetor do tipo "proporcional", com ponto de operação de 1 dividido pela relação de ar/combústivel (AFR). Esses valores de AFR foram calibrados de acordo com as respectivas rotações, e podem variar entre 10 e 12,4.

Para o perfil de levante das válvulas e coeficiente de descarga, foram utilizados coeficientes padronizados de outros estudos no software, com valores que variam de 0 a $8 \mathrm{~mm}$ para o levante e 0 a 0,815 para o coeficiente. 
O bloco de motor utilizado no modelo simulado é de um motor "em linha" com mistura homogênea, 4 tempos por ciclo e 2 cilindros. $O$ modelo para 0 atrito utilizado foi o "Default Chen-Flynn Friction", já padrão no software.

Com todas essas informações, foi possível realizar o estudo do fluxo de massa de ar/combustível e queima nos cilindros. Assim como citado anteriormente, os gráficos de potência, torque, pressão média efetiva, temperatura e pressão na admissão foram extraídos e todos exportados para o excel, a fim de facilitar a comparação entre as condições e resultados das simulações. Estas comparações e as respectivas discussões serão apresentadas na próxima seção. 


\section{RESULTADOS E DISCUSSÕES}

Após a realização dos testes em dinamômetro com as configurações de motor listadas no capítulo anterior, foi feita uma análise comparativa dos resultados em relação às simulações efetuadas. Nas Figuras 47 e 48 - que permitem comparar resultados da simulação e dos ensaios experimentais para o caso do motor naturalmente aspirado - é possível observar que a simulação foi capaz de reproduzir algumas características do motor de maneira satisfatória. Para começar, pelos valores de potência e torque resultantes, que estão dentro da ordem de grandeza esperada. Verificou-se que a diferença entre os dados reais e simulados é de, em média, 19\% (Figura 49). Isso se dá pelo fato de que, conforme apontado no capítulo anterior, a medição com dinamômetro de rolo inclui as perdas associadas à transmissão do veículo como um todo, se comparado com um dinamômetro de bancada. Ao contrário da simulação, que foi realizada de forma a extrair dados de desempenho provenientes diretamente do virabrequim do motor - sem quaisquer perdas de transmissão. De acordo com dados adquiridos em um outro veículo da mesma competição de fórmula SAE, Kuniyoshi et al. (2010) evidenciam que as perdas podem ser superiores a 15\%, uma ordem de grandeza também assumida pela norma SAE J1349 e semelhante ao que se visualizou de diferença entre a simulação e os ensaios no dinamômetro. Ao comparar ambos os gráficos foi possível também verificar que fenômenos acústicos importantes acontecendo nos dutos de admissão e exaustão puderam ser reproduzidos pela simulação (tomando como exemplo os picos e vales ocorrendo na curva de torque entre 5 e 9 mil RPM. Como a potência nada mais é do que a multiplicação do torque pela rotação, um comportamento semelhante também pode ser visto nessa curva). 
Figura 47 - Curvas de potência do motor original naturalmente aspirado simuladas via software Ricardo Wave e aferido no dinamômetro.

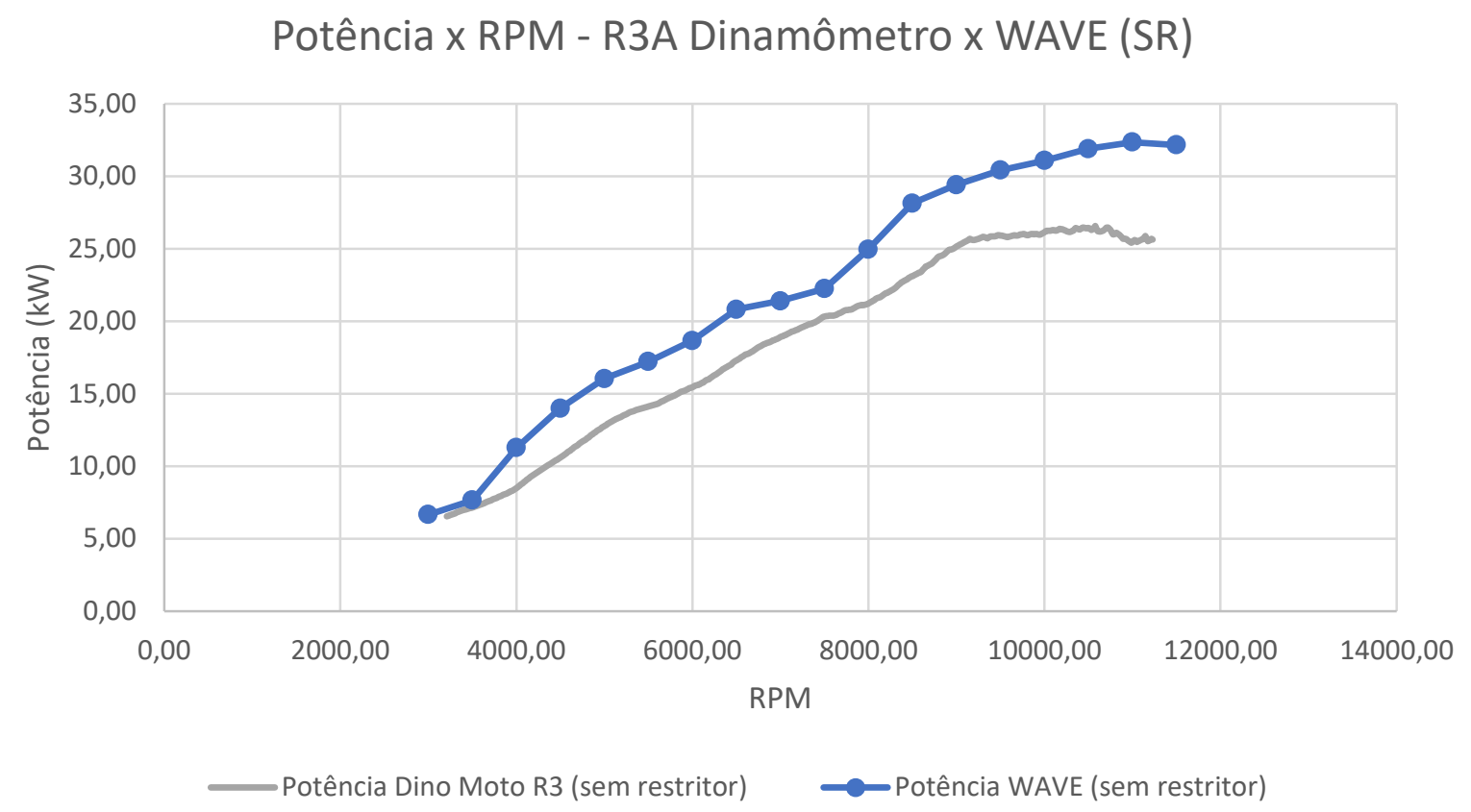

Fonte: Elaboração própria.

Figura 48 - Curvas de torque do motor original naturalmente aspirado simuladas via software e aferido no dinamômetro.

Torque x RPM - R3A Dinamômetro x WAVE (SR)

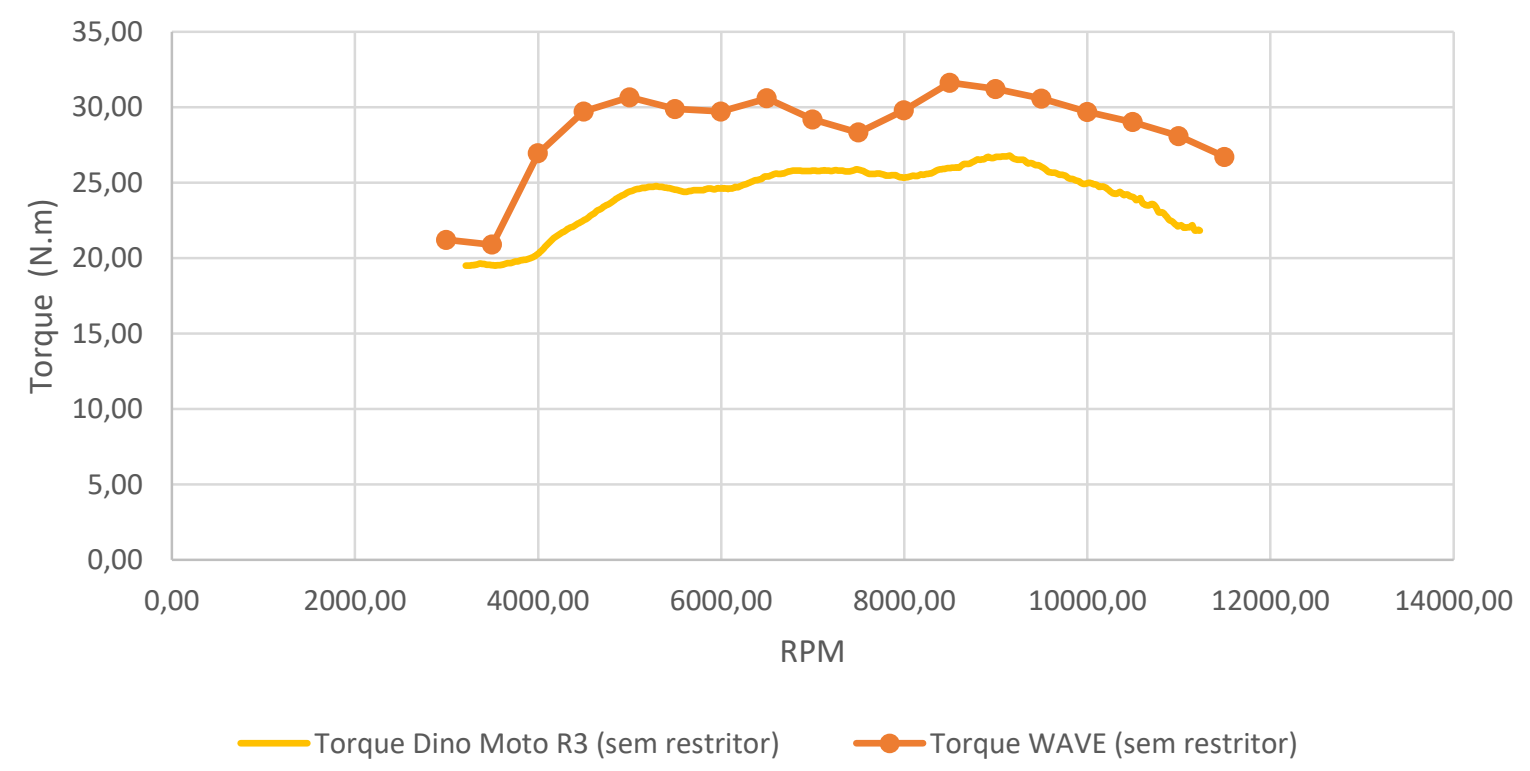

Fonte: Elaboração própria. 
Figura 49 - Coeficiente da diferença de potência entre real e simulado.

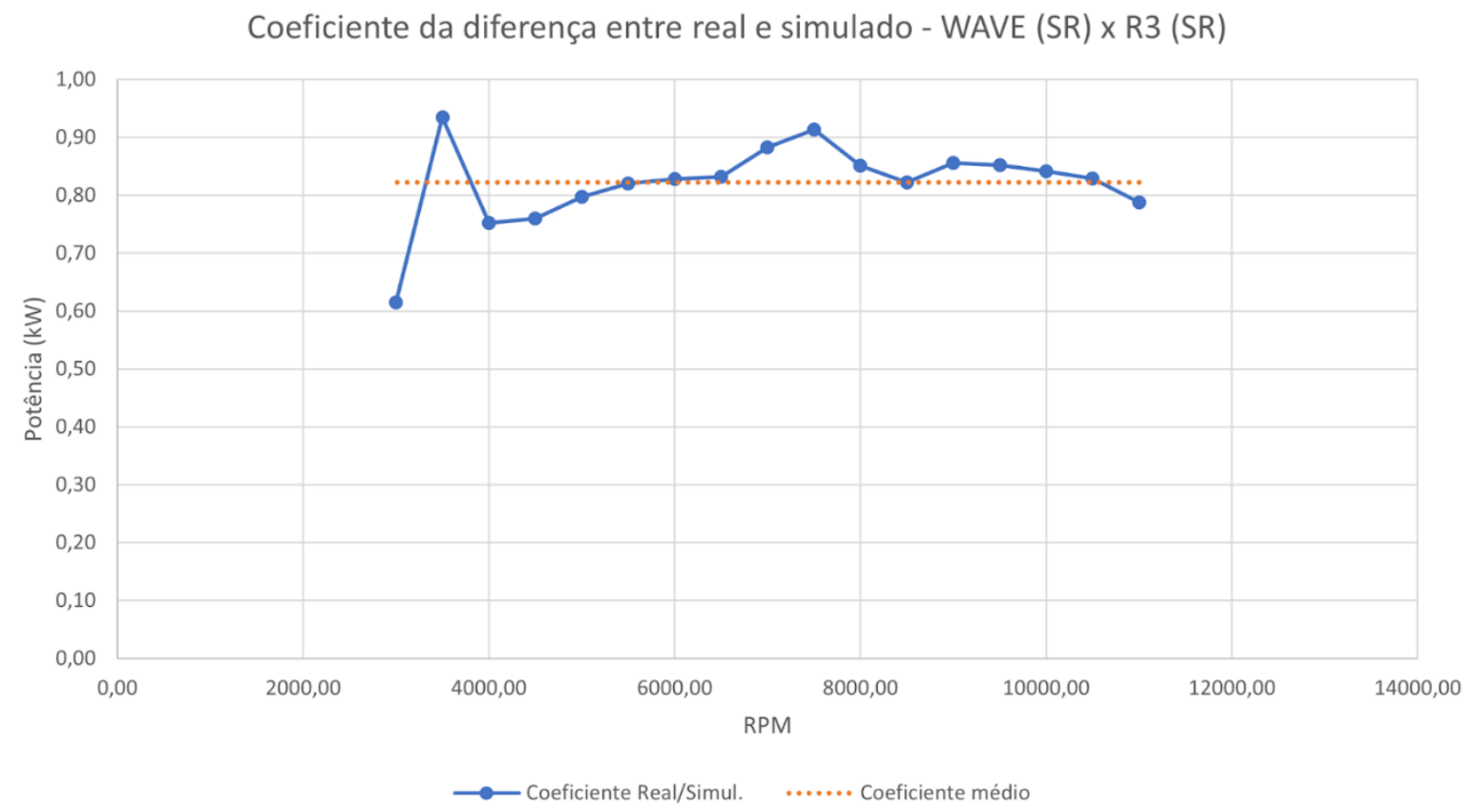

Fonte: Elaboração própria.

A partir das curvas experimentais de potência e torque da moto e do carro (Figuras 50 e 51) nota-se que o desempenho do motor no carro foi inferior ao da moto. Essa diferença pode ser explicada pelos seguintes fatores: o primeiro é o fato de que a eficiência do sistema de transmissão do carro é inferior à da moto. $O$ sistema de transmissão do carro conta com a presença de duas rodas e pneus largos - contra uma roda na moto e pneu mais fino, e um par de semi-árvores com juntas homocinéticas, conectados pelo conjunto diferencial e coroa, transmitindo a rotação até aos mancais da manga traseira de suspensão. $O$ segundo fator é a mudança de alguns sistemas ligados ao motor, como a alteração do sistema de admissão e exaustão para possibilitar a adaptação do turbo (como por exemplo a modificação do coletor de escape, que para fins de empacotamento e eficiência de funcionamento da turbina tem um comprimento mais curto que o original, alterando o comportamento do motor em baixas rotações), e a calibração do sistema de ignição e injeção. Para a adaptação do motor no carro - visando a sobrealimentação e a mudança de combustível para o etanol, utilizou-se um sistema de injeção eletrônica programável que foi calibrado pelo autor. Nota-se uma pequena discrepância no comportamento das curvas em rotações inferiores a 6000 RPM, por esse motivo vale 
a pena ressaltar o pouco tempo investido para afinar o motor nessas condições de contorno -regimes não muito comuns em uma situação de competição com o carro.

Figura 50 - Curvas de potência no dinamômetro com o motor naturalmente aspirado na moto Yamaha R3 e no carro (sem restritor).

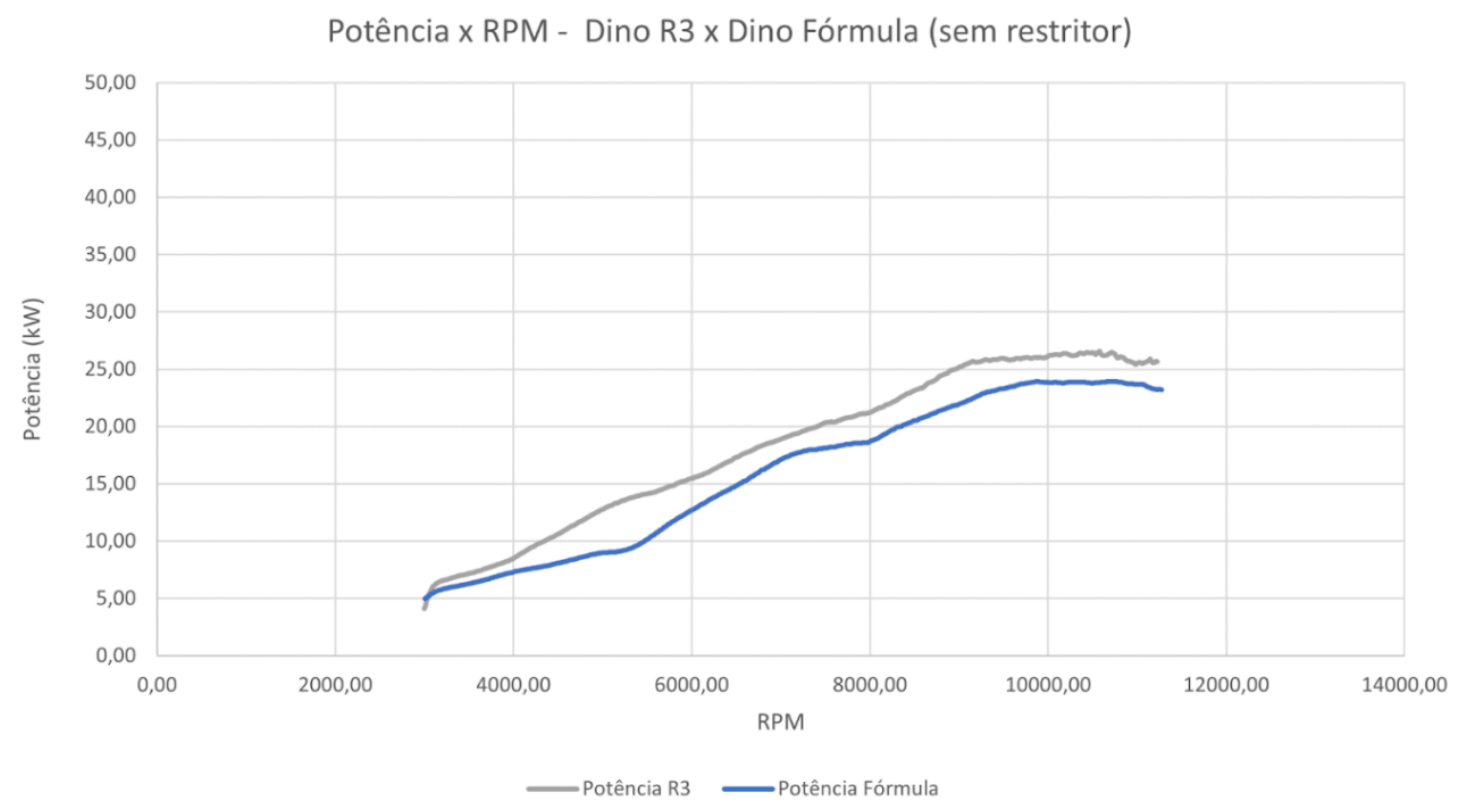

Fonte: Elaboração própria. 
Figura 51 - Curvas de torque no dinamômetro com o motor naturalmente aspirado na moto Yamaha R3 e no carro (sem restritor).

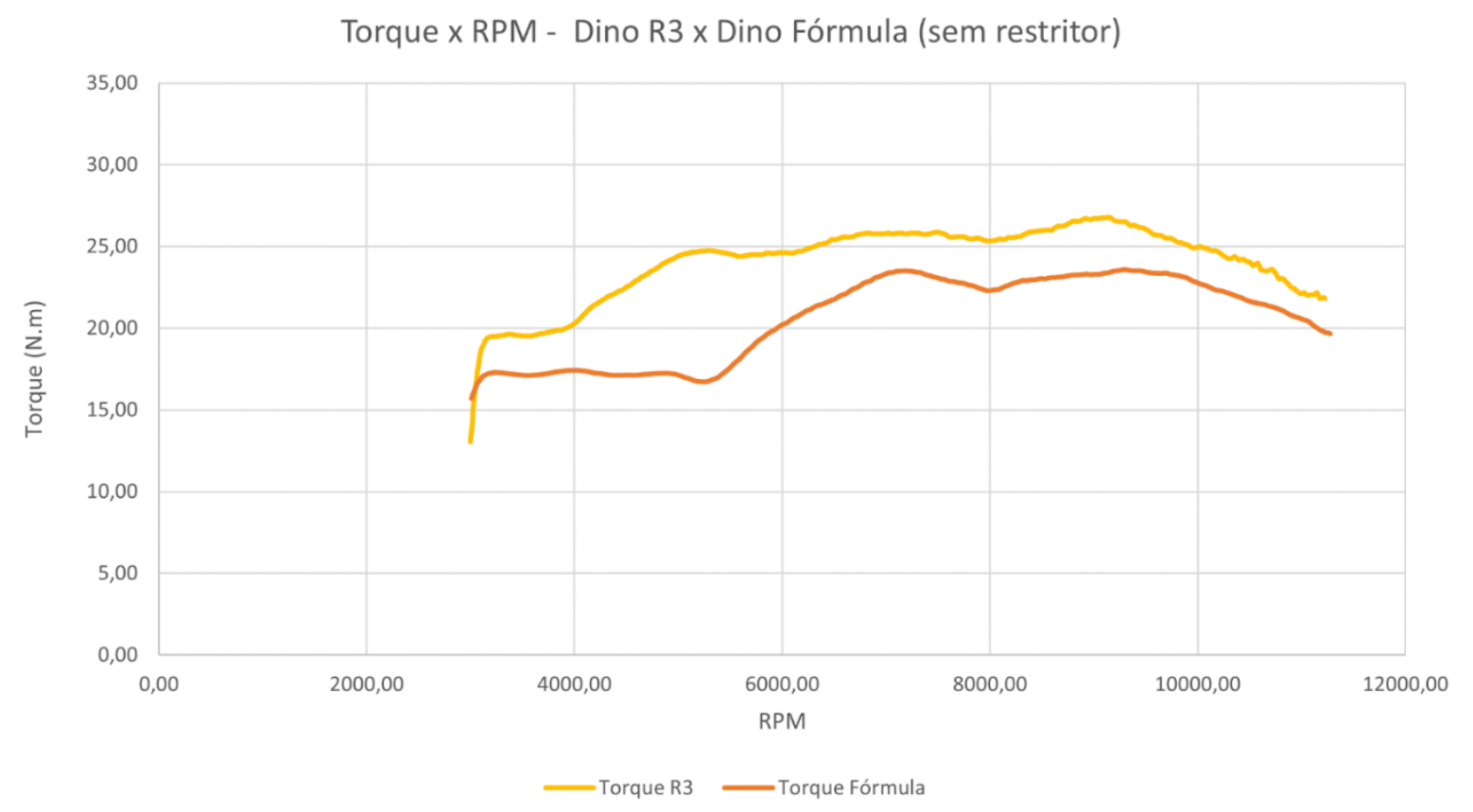

Fonte: Elaboração própria.

Ao se analisar as curvas com restritor (Figuras 52 e 53) percebe-se pouca influência da restrição de $19 \mathrm{~mm}$ nos picos de torque e potência do motor. Isso é explicado pelo fato de que com o deslocamento de $320 \mathrm{cc}$ e a rotação de trabalho não ultrapassando os 12000 RPM, a vazão mássica de ar consumida pela admissão do motor - que segundo o regulamento da competição deve passar inteiramente pelo restritor, não ultrapassa a velocidade do som nesta região. Segundo Fox et al. (2014), quando a velocidade de escoamento de um gás em um duto ultrapassa a velocidade do som, ocorre um bloqueio sônico no duto. O bloqueio sônico é um fenômeno que ocorre em dutos onde a velocidade do fluido é igual ou maior que a do som no meio, ao atingir esta velocidade o fluido atinge um ponto máximo de vazão mássica que não pode ser ultrapassada devido a um estreitamento da seção útil de passagem do fluido gerado pelo próprio gás. Como a velocidade nesta seção não atingiu Mach 1, não houve uma restrição na vazão mássica do ar de admissão. 
Figura 52 - Curvas de potência aferidas no dinamômetro com o motor naturalmente aspirado no carro (com e sem restritor).

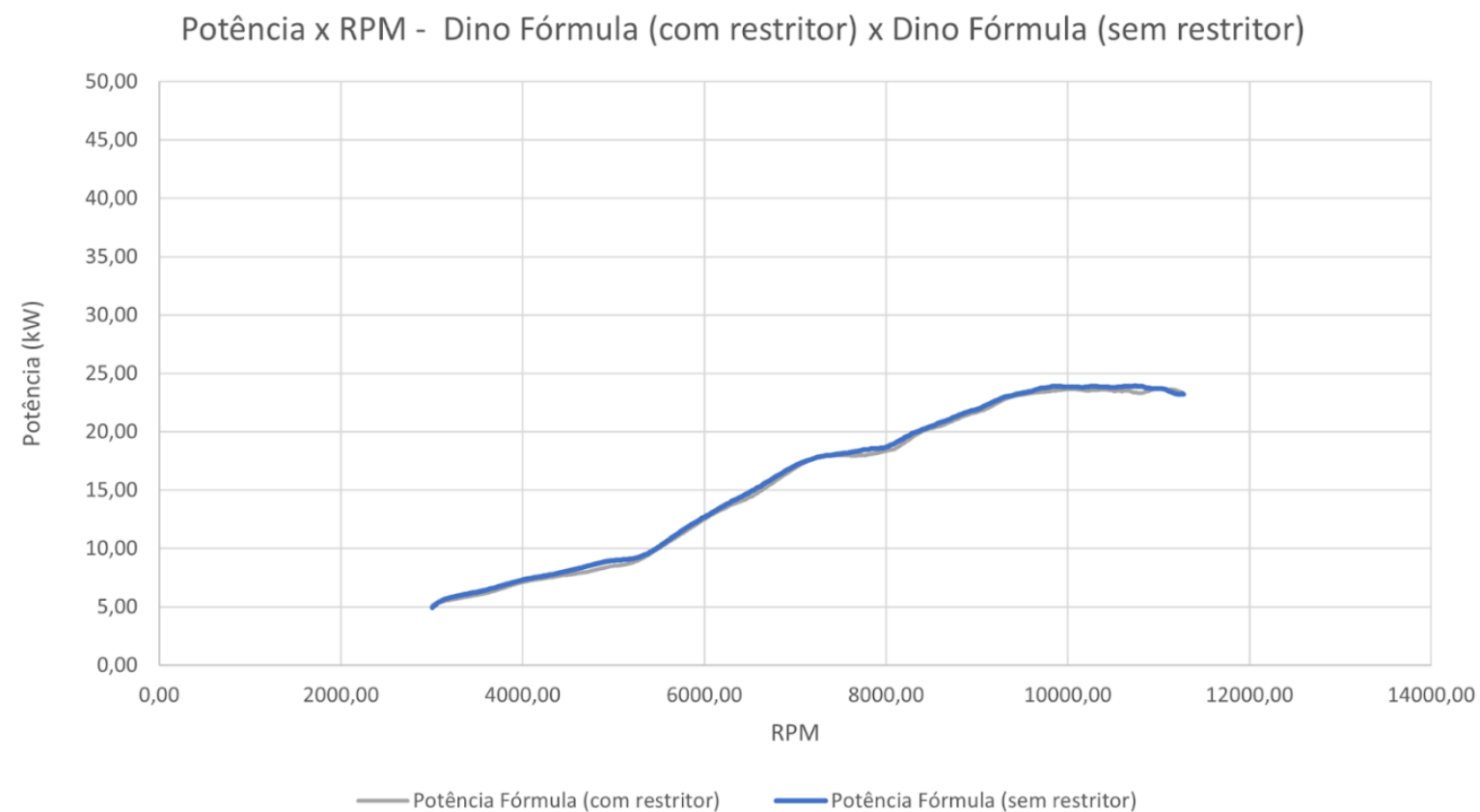

Fonte: Elaboração própria.

Figura 53 - Curvas de torque aferidas no dinamômetro com o motor naturalmente aspirado no carro (com e sem restritor).

Torque x RPM - Dino Fórmula (com restritor) x Dino Fórmula (sem restritor)

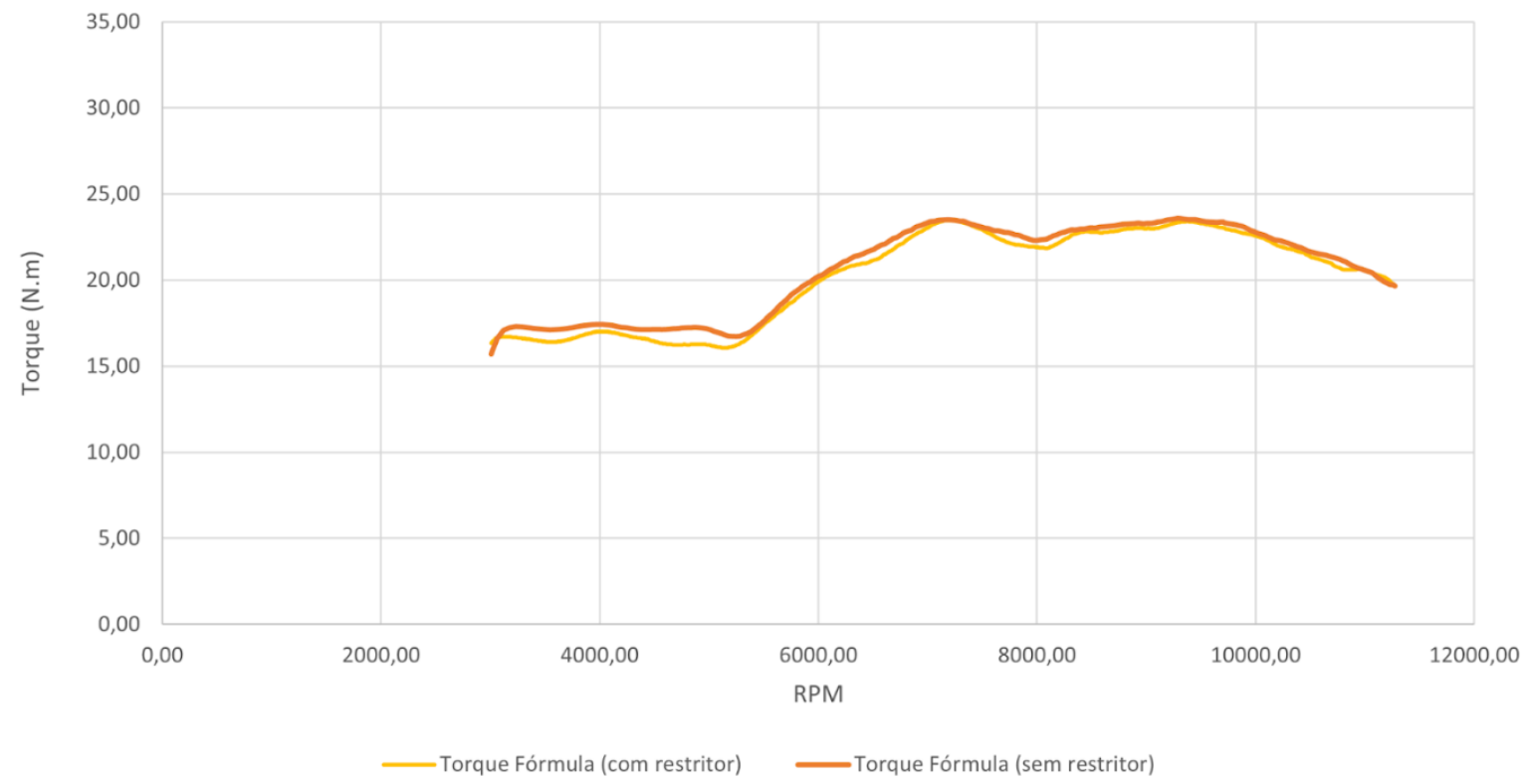

Fonte: Elaboração própria. 
A Figura 54 mostra a comparação do desempenho do motor na condição sobrealimentada, com e sem restritor. Devido a dificuldades de execução e cumprimento de prazos ocorridos no ano de 2020 e 2021, após uma série de falhas em alguns componentes do carro (falhas eletrônicas e deslizamento dos discos de embreagem), os testes em dinamômetro não puderam ser repetidos a fim de se realizar e mensurar a configuração sobrealimentada com restritor. Por isso, as curvas mostradas na Figura 54 correspondem ao caso de motor turboalimentado com e sem restritor resultantes da simulação. De qualquer forma, é evidente que o restritor na entrada de ar não resultou em uma redução significativa nos valores de potência e torque, mesmo após o motor ser sobrealimentado.

Figura 54 - Curvas de potência e torque com motor sobrealimentado com e sem restritor resultantes da simulação.

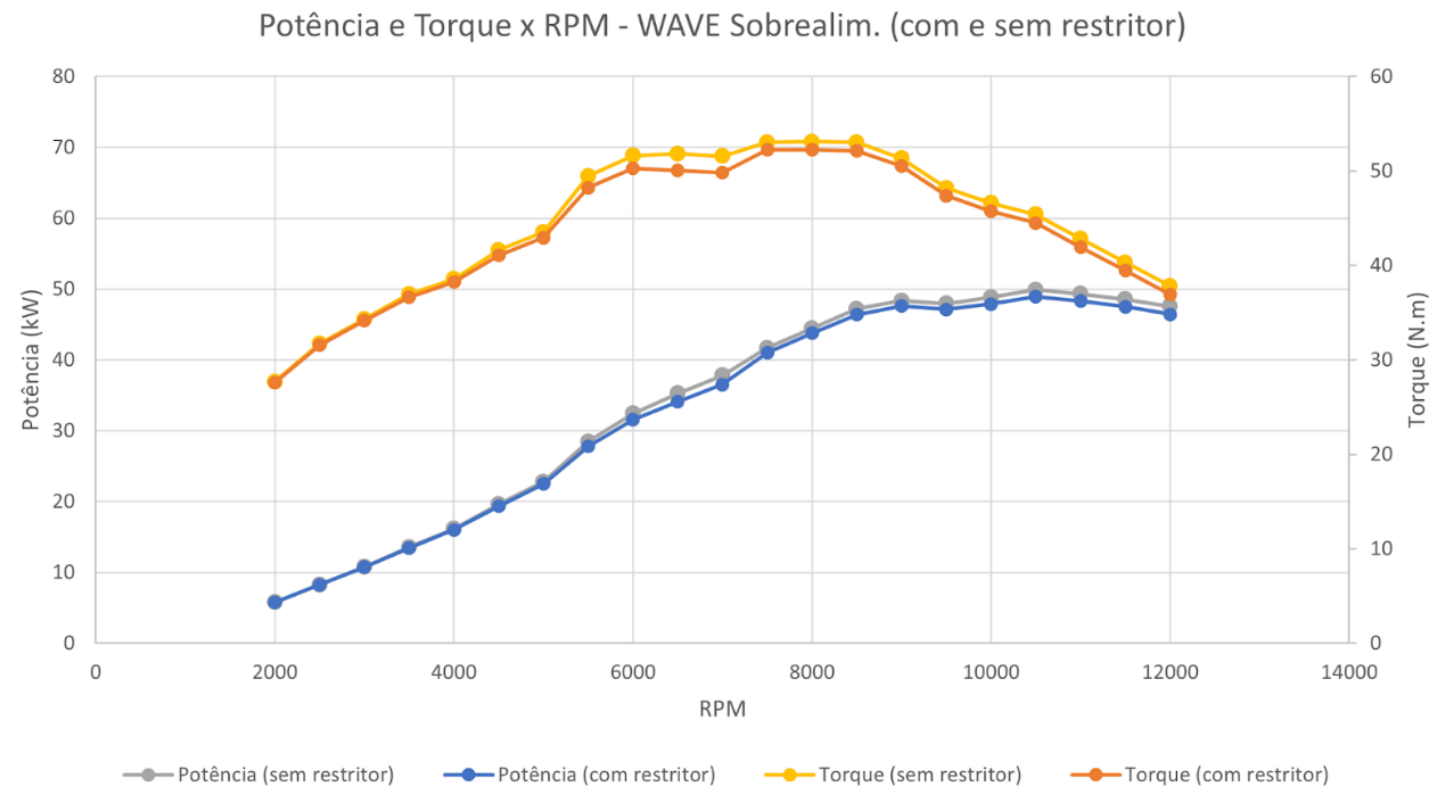

Fonte: Elaboração própria.

Apesar de não ter apresentado grandes efeitos na potência e no torque, os impactos da aplicação do restritor de ar no veículo sobrealimentado não podem ser desprezados. A sobrealimentação aumenta significativamente a vazão mássica de 
ar, e mesmo que a velocidade do som não tenha sido atingida, as perdas de carga começam a se acentuar. Esse fenômeno pode ser verificado a partir da visualização dos regimes de funcionamento do motor no mapa do compressor (Figura 55). Notase que na condição com restritor, a razão de compressão requerida nas mesmas condições de contorno é maior. Verifica-se isso devido ao fato de que - para que o compressor seja capaz de entregar os mesmos 0,7 bar de pressão relativa na saída - a válvula wastegate abre-se menos (Figura 56), acelerando a rotação do compressor até o momento que a pressão de admissão pré estabelecida seja atingida. Apesar de este comportamento ser benéfico para amenizar as perdas de desempenho geradas pelo restritor, o aumento da rotação do turbocompressor para compensar esta queda da pressão acarreta em um maior estresse no funcionamento do componente, diminuindo sua eficiência e possivelmente sua vida útil.

Figura 55 - Mapa do compressor mostrando os regimes de trabalho nas condições sem restritor(sem contorno) e com restritor (com contorno azul).

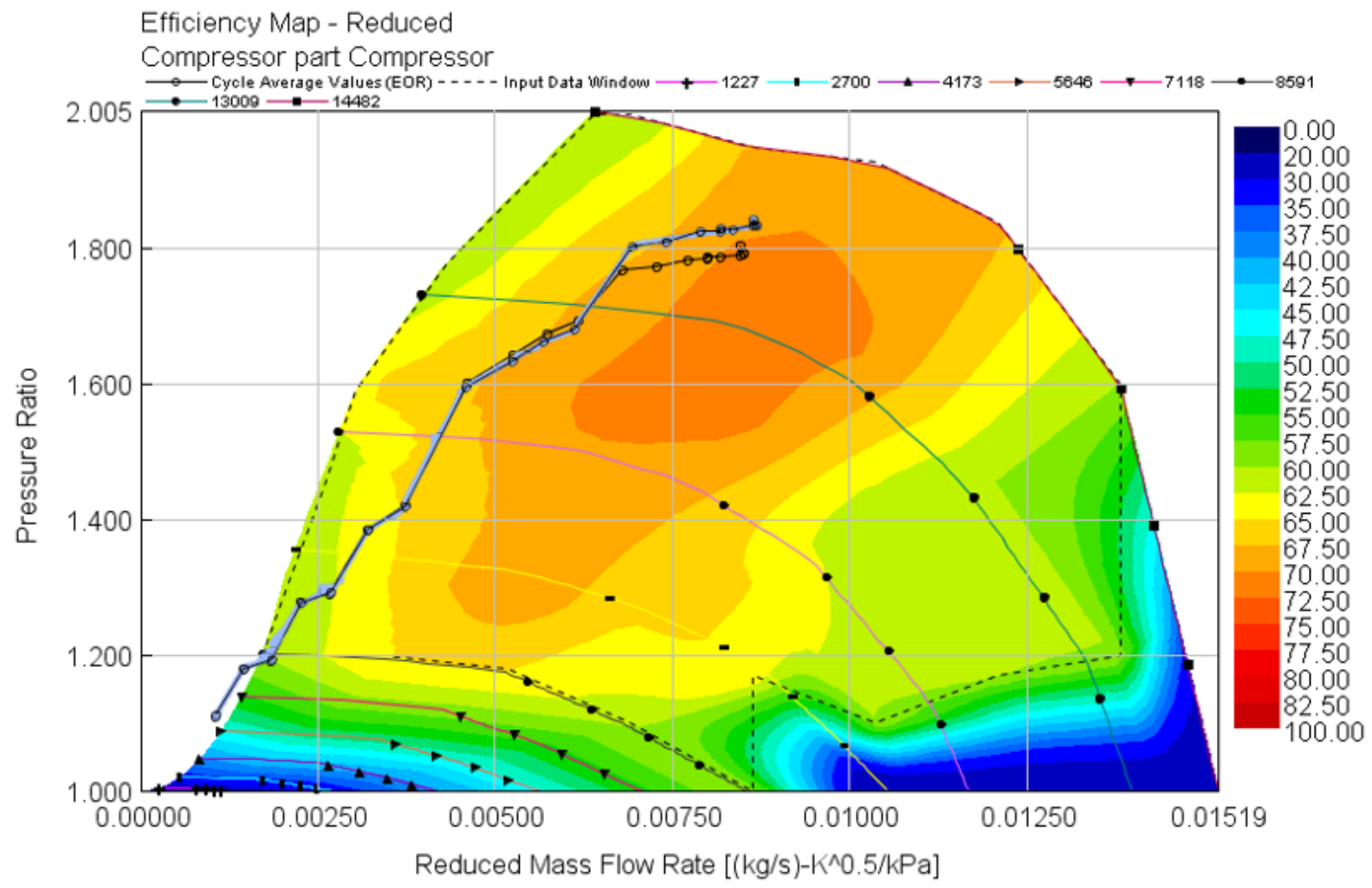

Fonte: Elaboração própria. 
Figura 56 - Diâmetro teórico da wastegate com restritor e sem restritor no software Ricardo Wave.

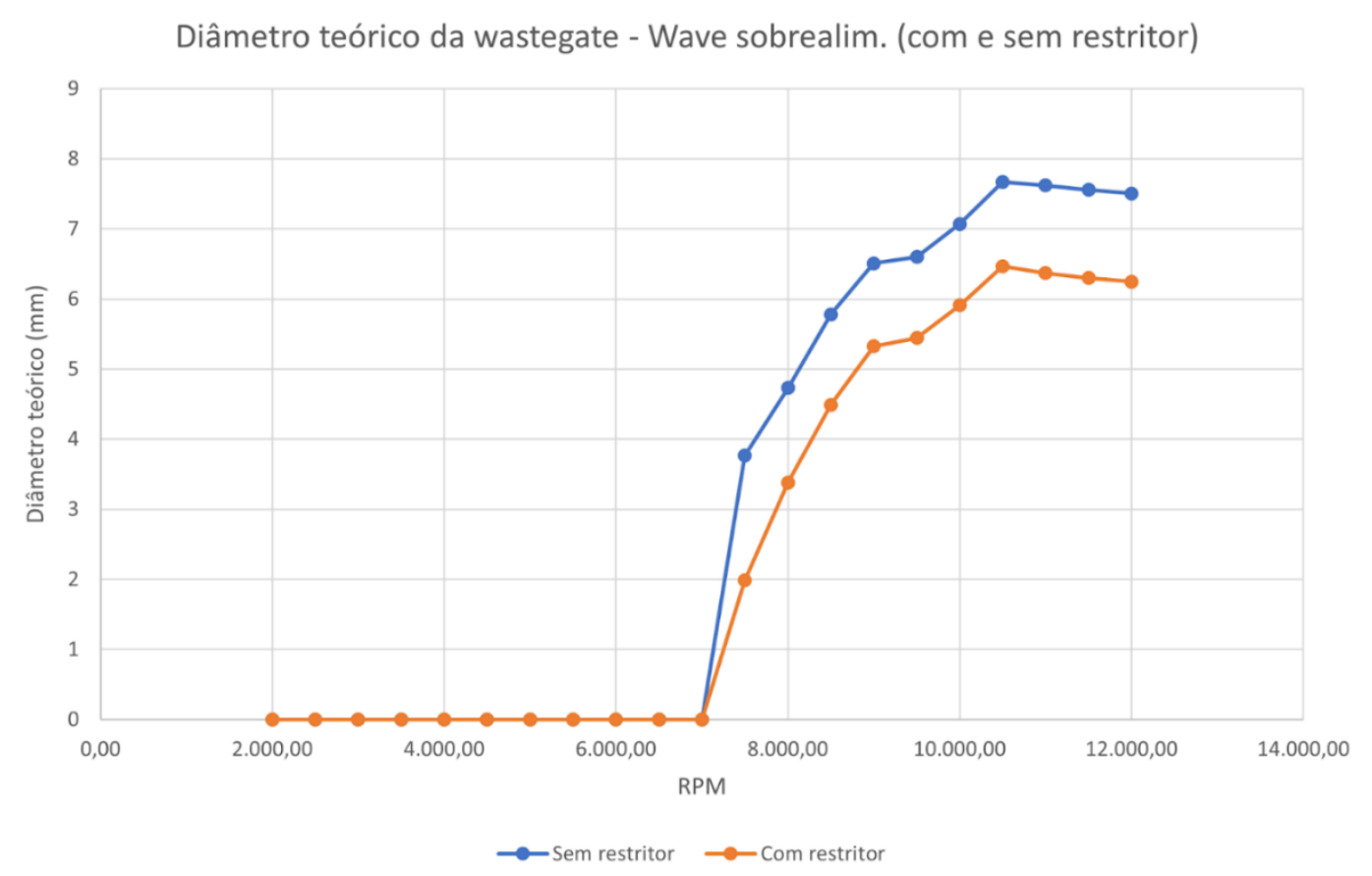

Fonte: Elaboração própria.

As Figuras 57 e 58, que comparam o rendimento do motor equipado no carro naturalmente aspirado contra o desempenho sob os efeitos da sobrealimentação, mostram que os ganhos após a montagem do sistema com turbocompressor foram significativos. O pico de potência foi aumentado em $69 \%$, já o de torque, em $73 \%$. Embora ganhos sejam perceptíveis em toda a faixa de rotação, nota-se que é a partir de aproximadamente 5000 RPM que o compressor começa a gerar pressões significativas no sistema de admissão. Nota-se que o comportamento da curva de torque (Figura 57) seguiu o previsto pela literatura, conforme indicado pela Figura 2. 
Figura 57 - Curvas de torque com motor sobrealimentado sem restritor e motor naturalmente aspirado, aferidos no dinamômetro.

Torque $x$ RPM

Dino Formula aspirado (sem restritor) e Dino Formula sobrealimentado (sem restritor)

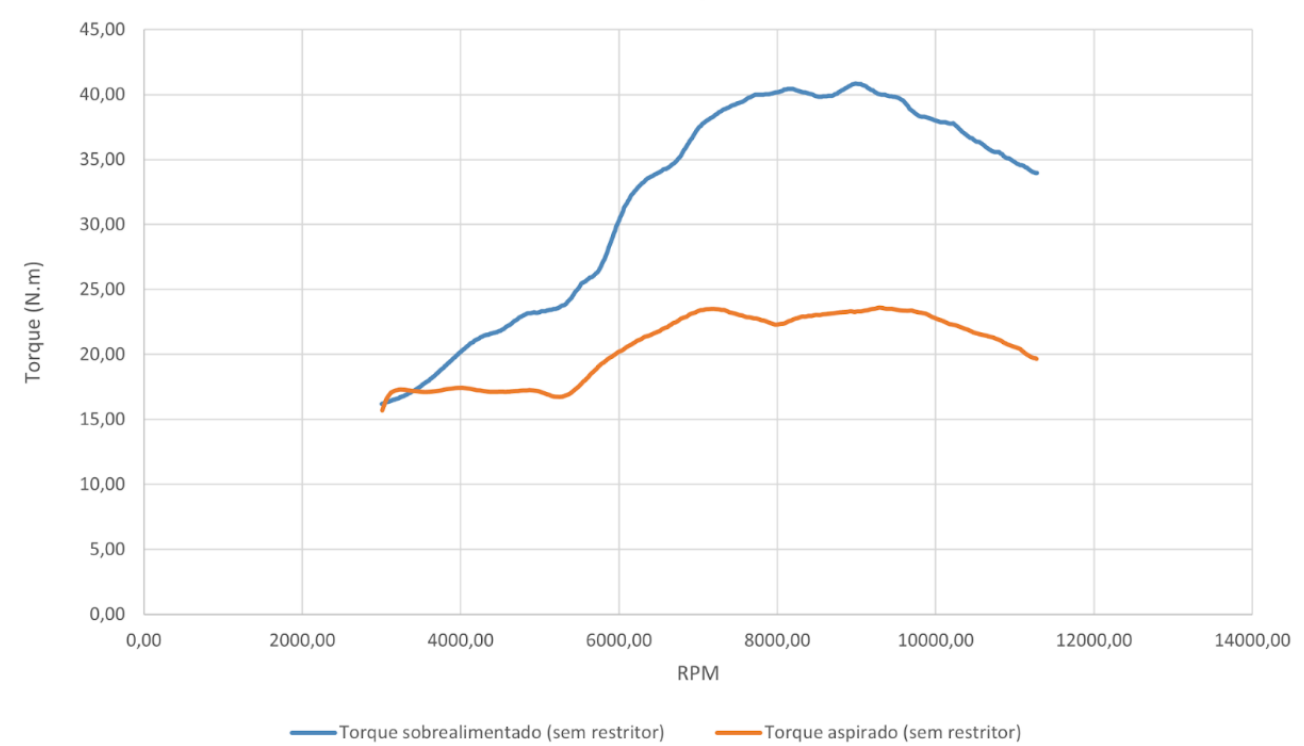

Fonte: Elaboração própria.

Figura 58 - Curvas de potência com motor sobrealimentado sem restritor e motor naturalmente aspirado, aferidos no dinamômetro.

Potência x RPM

Dino Formula aspirado (sem restritor) e Dino Formula sobrealimentado (sem restritor)

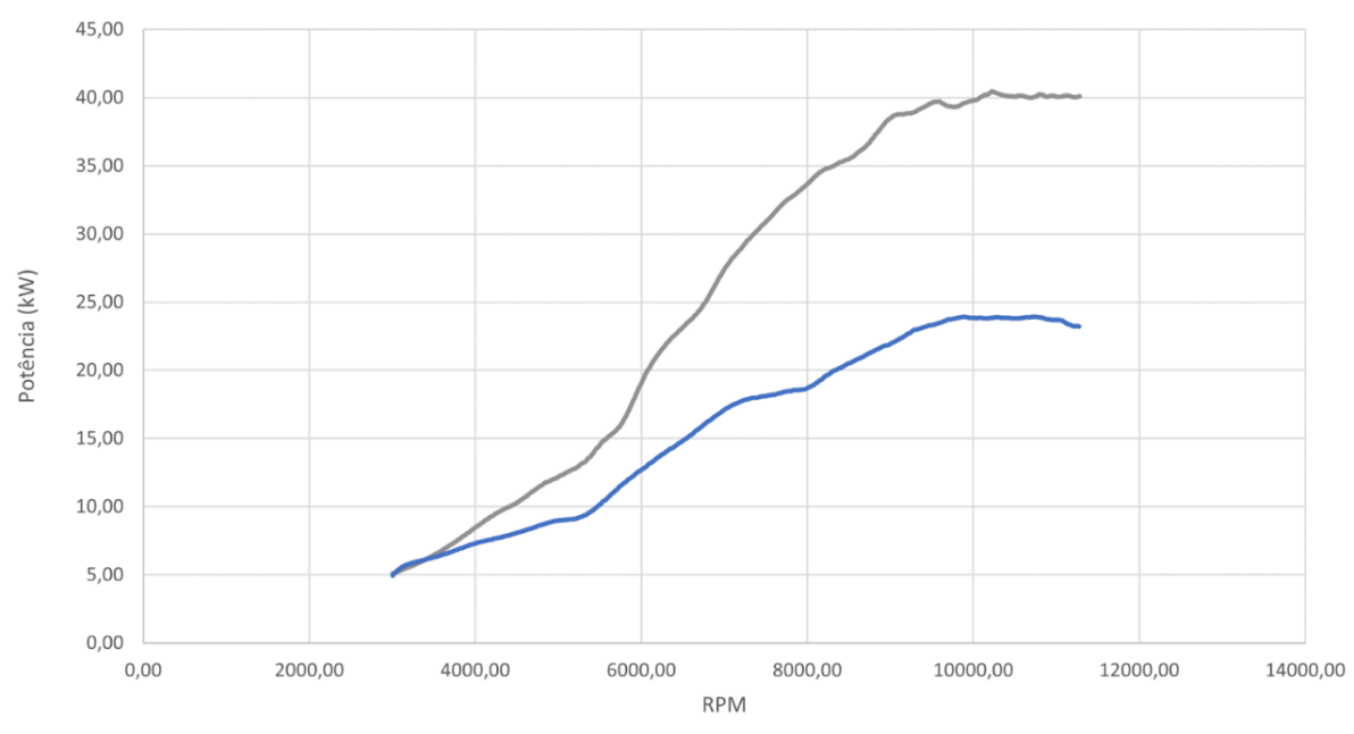

— Potência sobrealimentado (sem restritor) _ _ Potência aspirado (sem restritor)

Fonte: Elaboração própria. 
A simulação da configuração sobrealimentada também gerou resultados satisfatórios, que foram capazes de prever o comportamento das curvas de torque e potência que foram medidas em dinamômetro. A diferença nos resultados, considerando as perdas de transmissão, foram semelhantes às encontradas nos testes com o motor naturalmente aspirado. Vale ressaltar que devido ao fato de ser uma modificação nova e ainda pouco testada, manteve-se uma postura conservadora na calibração do mapa de avanço de ignição, enquanto que a simulação considera valores de avanço perto do otimizado. Logo, é possível afirmar que ainda há a possibilidade de existir uma pequena margem de desempenho a ser ganha no motor real. A comparação dos resultados das curvas de torque e potência podem ser visualizados nas Figuras 60 e 61 respectivamente.

Figura 59 - Curvas de torque com motor sobrealimentado sem restritor e motor naturalmente aspirado sem restritor comparados entre software de simulação e dinamômetro.

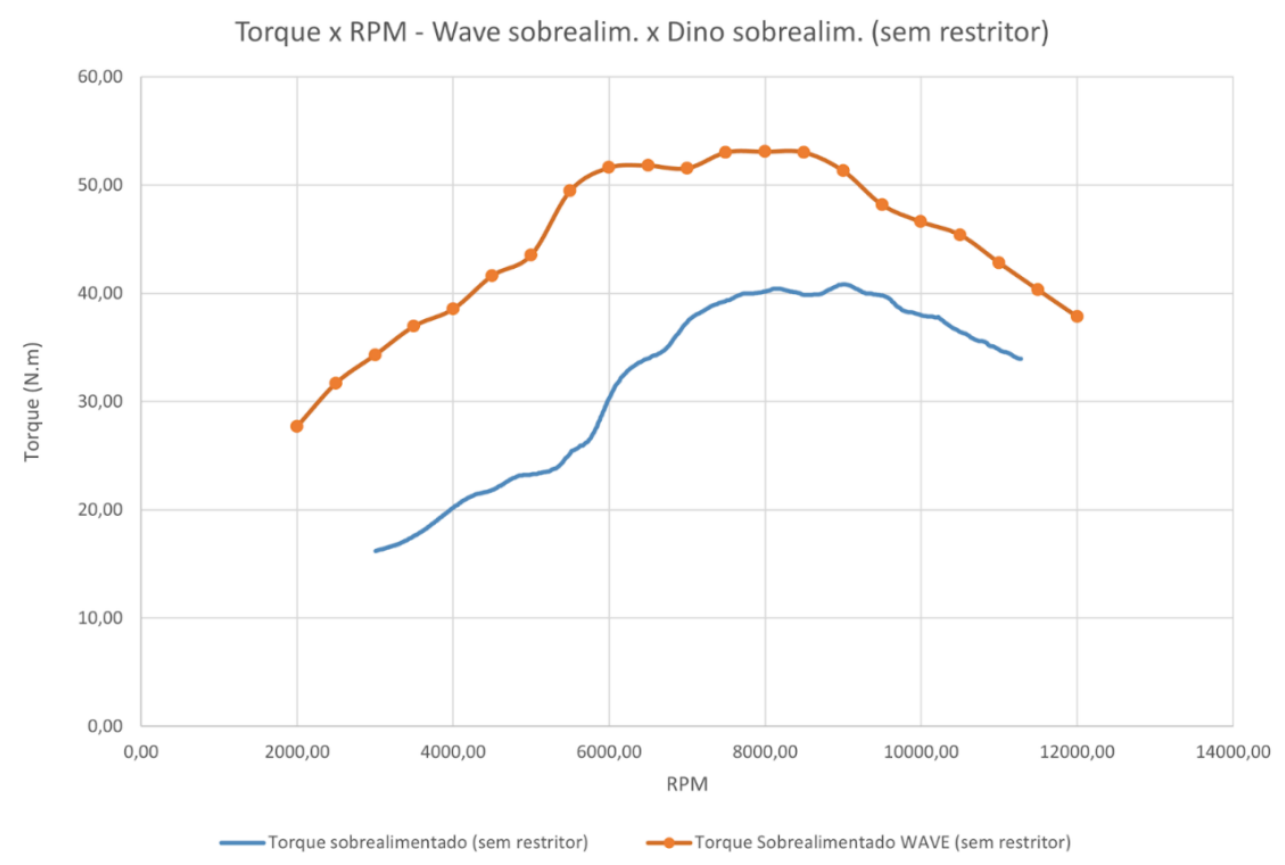

Fonte: Elaboração própria. 
Figura 60 - Curvas de potência com motor sobrealimentado sem restritor e motor naturalmente aspirado sem restritor, comparado entre software de simulação e dinamômetro.

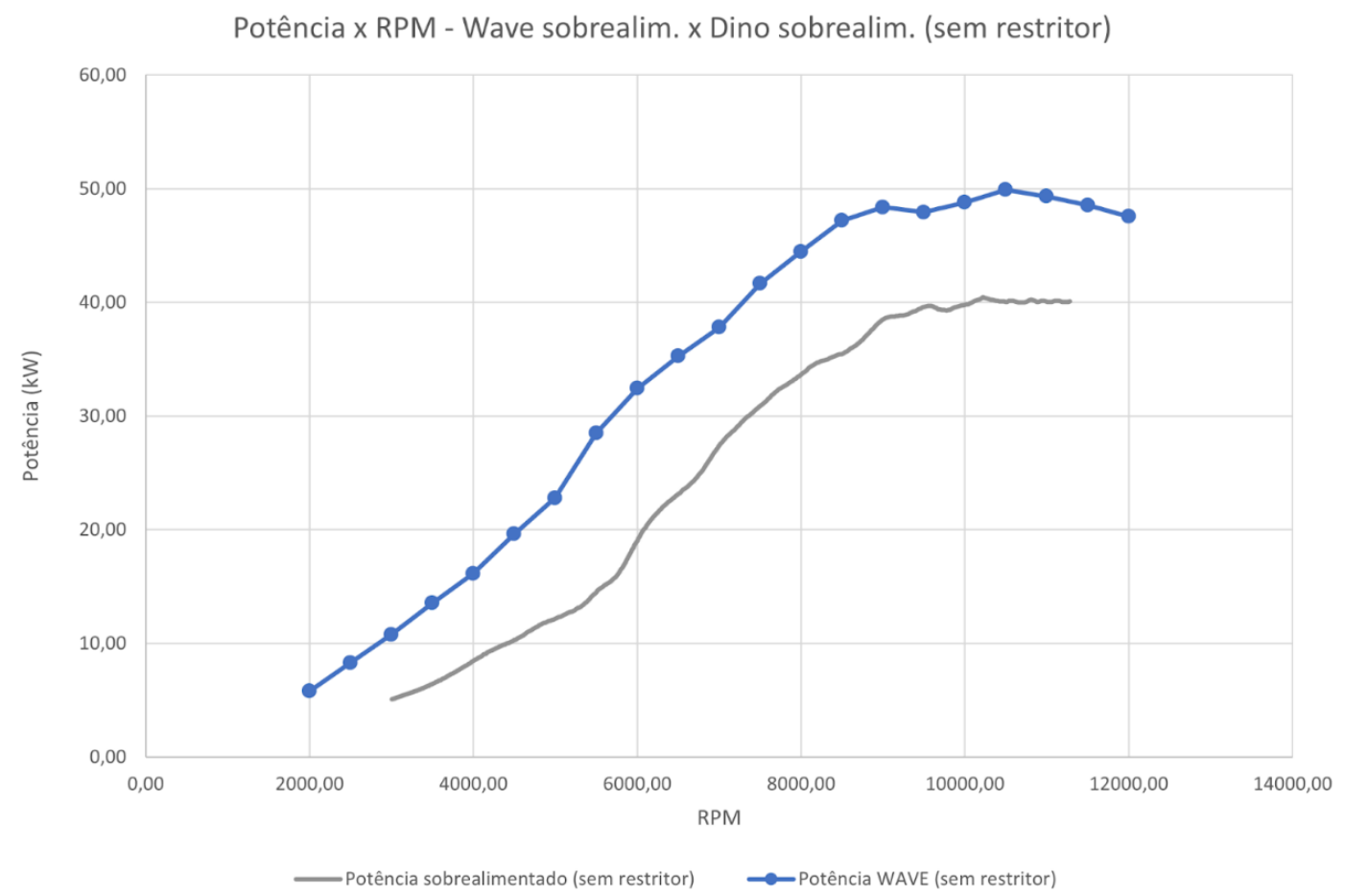

Fonte: Elaboração própria. 


\section{CONCLUSÕES}

Levando em consideração o que foi apresentado nas seções anteriores deste estudo, foi possível concluir que os resultados das simulações realizadas conseguiram replicar os resultados obtidos no dinamômetro, sendo que a diferença entre os ensaios e a simulação atingiu uma média de $19 \%$ (valor similar às perdas gerais para o sistema de transmissão em veículos desse tipo), e o formato das curvas se manteve.

A aplicação do restritor na admissão de ar do veículo - a fim de cumprir com o regulamento da competição não resultou em perdas significativas de desempenho do veículo, seja ele na configuração naturalmente aspirada ou na sobrealimentada, principalmente pelo fato que a velocidade do ar admitido não ultrapassou a velocidade do som nesta região. Entretanto, foi possível notar um aumento na rotação de trabalho do turbocompressor, a fim de compensar as perdas de carga geradas pela restrição.

Ao se comparar com o desempenho nas condições originais, a aplicação do turbocompressor foi capaz de gerar ganhos expressivos no desempenho do motor (ganhos em torno de $69 \%$ na potência e de $73 \%$ no torque).

A simulação se mostrou um instrumento útil na análise de propostas de modificações do motor, a fim de prever o comportamento do motor de diversas maneiras antes que elas sejam executadas e propriamente testadas. Este estudo abordou apenas resultados de potência e torque, porém informações mais específicas a respeito do comportamento térmico e fluidodinâmico do sistema também podem ser obtidas a partir dessas ferramentas.

Acredita-se ainda que as informações reunidas neste trabalho possam amparar projetos de desenvolvimento acadêmico dentro da universidade que utilizam motores de combustão interna - como BAJA e Fórmula SAE a fim de compreender melhor os fenômenos que regem essa máquina térmica e otimizar suas características de operação. 


\section{SUGESTÕES PARA TRABALHOS FUTUROS}

A partir dos resultados obtidos neste trabalho e de sua análise foi possível elaborar propostas para a realização de trabalhos futuros, conforme segue:

a) Estudo e fabricação de comando de válvulas específico para o motor turboalimentado, explorando melhor o cruzamento de válvulas, que favoreça o turbocompressor.

b) Estudo e fabricação para um coletor de admissão com melhor performance e aproveitamento para o turbocompressor.

c) Estudo para o intercooler ter uma melhor eficiência, devido à alta temperatura do motor e a falta de circulação de ar nesta região, podendo ser utilizado um intercooler do tipo ar-água.

d) Realização de medições em um dinamômetro de bancada para que a potência possa ser medida diretamente no eixo virabrequim, sem ter perdas com as transmissões. 


\section{REFERÊNCIAS}

AHMED, A.; WAHAB, M.S.; RAUS, A.A.; KAMARUDIN, K.; BALA, A.S.; RAMLI, M.B. Mechanical and Thermal Issues in Downsize Engine: A Review. International Journal of Engineering \& Technology, 2018.

ALL ABOUT INTERNAL WASTEgATE. Disponível em: $<$ https://www.treadstoneperformance.com/blog/all-about-internal-wastegates-fromturbosmart>. Acesso em 25 de Janeiro de 2020.

ANP, A.N.D.P. - RESOLUÇÃO ANP NUMERO 19. Disponível em: http://www.anp.gov.br/biocombustiveis/etanol , Acesso em 04/08/2020.

BAÊTA, J. G. C. Metodologia Experimental para a Maximização do Desempenho de um Motor Multicombustível Turboalimentado sem prejuízo à Eficiência Energética Global. Tese de Doutorado, UFMG, 2006.

BASSHUYSEN, V.; SCHAFER, R.; Modern Engine Technology, SAE, 2006.

BELL, C. Maximum Bosst: Designing, Testing and Installing Turbocharger Systems. Bentley Publishers, 1997.

BERNARDI, S. Projeto de uma bancada de fluxo para cabeçotes de motores de baixa cilindrada unitária. 105f. TCC (Graduação) - Engenharia Mecânica, Universidade Federal do Pampa, Alegrete, 2015.

BLAIR, G. P. Design and Simulation of Four Stroke Engines. SAE International, 1999.

BORETTI, A. Analysis of Design of Pure Ethanol Engines. SAE 2010-01-1453, p. $1-13,2010$. 
BORETTI, A. Towards $\mathbf{4 0} \%$ efficiency with BMEP exceeding $\mathbf{3 0}$ bar in directly injected, turbocharged, spark ignition ethanol engines. Energy Conversion and Management, v. 57, p. 154-166, 2012.

BRUNETTI, F. MOTORES DE COMBUSTÃO INTERNA, V.1, 2012.

CARVALHO, M G F. Análise de vibração e ruído em trens de válvulas de motores de combustão interna. Universidade Federal de Minas Gerais, 2009.

DONALDSON, M. J. Dynamic simulation of an electrohydraulic open center gasexchange valve actuator system for camless internal combustion engines. Master Thesis. University of Michigan, EUA, 2003.

DUARTE, H. V. Simulação do Efeito dos Parâmetros Operacionais no Desempenho de Motores de Combustão Interna., 1996.

FAGGI, R. Formação de Mistura de Ar Combustível em Motores de Ignição por Faísca a Quatro Tempos, 1aEd., 2012.

FERGUSON, C.; KIRKPATRICK, A. T. Internal Combustion Engines: applied thermodynamic. 2 ed. ISBN-0-471-35617-4 (cloth: alk. paper), 2000.

FIXED Geometry Turbochargers. dieselnet.com. Disponivel em: <https://www.dieselnet.com/tech/air_turbo_fixed.php>. Acesso em: 28 out. 2019.

FONTES, H.D., MARGEM, J.I., PESSANHA, E.M., AUATT, S.S.M. Redução das Dimensões dos Motores de Combustão Interna: Como manter ou Melhorar o Desempenho e Eficiência do Motor Utilizando Novas Tecnologias. Exatas \& Engenharias, 5 (13), 2015.

FOX, R.; PRITCHARD, P.; MITCHELL, J. Introdução a Mecânica dos Fluidos. 9a. ed. [S.I.]: LTC, 2014. 
GALLONI, E. Analysis About Parameters That Affect Cyclic Variation in a Spark Ignition Engine. Applied Thermal Engineering, 29, 1131-1137, 2009.

GANESAN, V. INTERNAL COMBUSTION ENGINES, 1995.

GOLLOCH, R. Downsizing Bei Verbrennungsmotoren. Springer-Verlag, Berlim, 2006.

GOODYEAR, Motores SOHC quatro cilindros. 2005. Disponível em: <http://www.goodyear.com.br/engineeringproducts> Acesso em: 25 de Janeiro de 2019.

GOUZONNAT, F.; MERCKX, P.; CAZENAVE, R.; LE COQ, S.; DEMESSE, F. New Challenges Encountered When Designing Highly Downsized Gasoline Engines (Through New PSA Peugeot Citroen Powertrain Examples). PSA Peugeot Citroen, 18, Rue Des Fauvelles, F-92256 La Garenne Colombes, France, 2015.

HEISLER, H. Advanced Engine Technology. SAE International, Head of Transport Studies. The College of North West London, Willesden Centre, London, UK, 1995.

HEISLER, H. Advanced Engine Technology. Society of Automotive Engineers , 2005.

HEYWOOD, J.B. INTERNAL COMBUSTION ENGINES FUNDAMENTALS, NeW York, Macgraw-Hill, 1988.

IHLEMANN, A. Sistemas de comando de válvulas para motores de combustão interna: Desenvolvimento, fabricação, aplicações. Verlag Moderne. Ed. Suddeutscher Verlag Onpact Gmbh, 81677 Munchen, 2003.

ISENSTADT, A.; GERMAN, J.; DOROBANTU, M.; BOGGS, D.; WATSON, T.; Downsized, Boosted Gasoline Engines. The International Council on Clean Transportation, 2016. 
KESGIN, U. Effect of Turbocharging System on The Performance of a Natural Gas Engine. Energy Conversation and Management, 2004.

LAINO, R. V. Estudo de como a Sobrealimentação aumenta a Eficiência Energética dos Motores Bicombustíveis. łaEd. São Caetano do Sul, 2014.

LIMA, E. N., Honda racing: Técnicas e métodos para preparação e desenvolvimento dos motores 4 tempos ohc/sohc-dohc motocicletas. Maringá, Autotech, 2018.

MAHLE, Curso Mahle Metal Leve, Motores de Combustão Interna - Aftermarket 2019/2020.

MARTINS, J. MOTORES DE COMBUSTÃO INTERNA, zaEdição, 2006.

MELO, T.C. et al. Hydrous Ethanol - Gasoline Blends - Combustion and Emission Investigations on a Flex-Fuel Engine. Fuel, v. 97, p. 796-804, 2012.

MELO, T. C. Modelagem Termodinâmica de um Motor de Ciclo Otto tipo FlexFuel, funcionando com Gasolina e Gás Natural. (Tese de Doutorado), Universidade Federal do Rio de Janeiro, 2007.

PATIL, C.; VARADE, S.; WADKAR, S. A Review of Engine Downsizing and Its Effects. International Journal of Current Engineering and Technology, 2017.

PETITJEAN, D.; BERNARDINI, L.; MIDDLEMASS, C.; SHAHED, S. Advanced Gasoline Engine Turbocharging Technology for Fuel Economy Improvements, SAE, 2004.

PIELECHA, I.; CIESLIK W.; BOROWSKI P.; CZAJKA J.; BUESCHKE W.; et al., Reduction of the Number of Cylinders in Internal Combustion Engines - 
Contemporary Trends in Downsizing. Combustion Engines. 159(4), 12-25. ISSN 2300-9896, 2014.

PULKRABEK, W. W. Engineering Fundamentals of the Internal Combustion Engine. 2 nd Ed. New Jersey: Prentice Hall, 1997.

PULKRABEK, W. Engineering Fundamentals of the Internal Combustion Engine., 2a Ed., 2003.

REGULAMENTO Fórmula SAE brasil 2019. fsaeonline.com. Disponivel em: $<$ https://www.fsaeonline.com/cdsweb/gen/DownloadDocument.aspx?DocumentID=6 4b861c2-980a-40fc-aa88-6a80c43a8540>. Acesso em: 17 out. 2019.

RICARDO, HARRY R. SIR. The High-Speed Internal Combustion Engine. Blackie \& Son Limited, 1931.

RICARDO SOFTWARE. WAVE User Manual, Version 2019.1 - March 2019. Van Buren Township: [s.n.], 2019.

RODRIGUES FILHO, F. A. Projeto, Construção e Caracterização do Desempenho de um Motor de Combustão Interna Provido de um Sistema de Ignição por Lança Chamas de Carga Estratificada. (Tese de Doutorado) UFMG, 2014.

ROMMER, A. Sistemas de comando de válvulas para motores de combustão interna: Desenvolvimento, fabricação e aplicações. Munique: Suddeutscher Verlag Onpact Gmbh, 2011.

SARATHY, S. M. et al. Alcohol Combustion Chemistry. Progress in Energy and Combustion Science, v. 44, p. 40-102, 2014.

SCHAEFFLER BRASIL LTDA (SOROCABA). Componentes do Trem de Válvulas e Variadores de Fase do Eixo Comando: Tecnologia e Diagnóstico de Falha. 2011. 
SELLNAU, M.; RASK, E. Two-step variable valve actuation for fuel economy, emissions, and performance. SAE Technical Paper pp. 01-0029, 2003.

SILVA, T. R. V. et al. Effects of Continuously Variable Valve Timing (cvvt) on Ethanol Spark Ignited Direct Injection (SIDI) Downsized Engine. Congresso Internacional de Motores, Combustíveis e Combustão - CIMCCO. Belo Horizonte, MG. Brasil: 7 p. 2016.

STONE, R., BALL, J. AUTOMOTIVE ENGINEERING FUNDAMENTALS. SAE, 1999.

STONE, R. INTRODUCTION OF INTERNAL COMBUSTION ENGINES, 2 Ed.,1992.

STUMPF, U.E. O Álcool Etílico Combustível de Motores. Petrobrás - Replan, 1975.

TOMOYOSE, R. Análise Dinâmica Não Linear de Sistema de Acionamento de Válvulas com Tucho Hidráulico. 122 f. Dissertação de Mestrado, Universidade Estadual de Campinas, Campinas, 2013.

TURNER, J.W.; HU, B.; AKEHURST, S.; BRACE, C.; COPELAND, C. Observations on and Potential Trends for Mechanically Supercharging a Downsized Passenger Car Engine: A Review. Journal of Automobile Engineering, 2016.

VAN DEN BRAEMBUSSCHE, R. Design and Analysis of Centrifugal Compressors. Asme Press \& John Willey \& Sons Ltd, 2018.

VELÁSQUEZ ALEGRE, J. A. A. Simulação dos Processos e Análise Exergética do Motor de Ciclo Diesel. Tese de Doutorado, Unicamp, 1993.

VELÁSQUEZ, J.A.; MILANEZ, L.F., Simulation of Admission and Exhaust processes in Diesel Engines, SAE Technical Paper 961124, SAE International, 1996. 
ZHAO, F.; LAI, M. C.; HARRINGTON, D. L. Automotive Spark-Ignited DirectInjection Gasoline Engines. Progress in Energy and Combustion Science, v. 25, n. 5, p. 437 - 562, 10// 1999.

ZHAO, H. Advanced Direct Injection Combustion Engine Technologies and Development. Boca Raton, FL, USA: Woodhead Publishing Limited and Crc Press LLC, 2010.

WGK, Indústria. Catálogo 2021. Disponível em: $</ /$ wgkindustria.com.br/produtos/yamaha/mt-03/arvore-do-comando-11/>. Acesso em 20 Out. 2021.

WINTERBONE, D. E.; NICHOLS, J. R.; ALEXANDER, G. I. Efficency of the Manifolds of Turbocharged Engines. Proceedings of The Institution of Mechanical Engineers, v. 199, p. 137-149, 1985. 